\title{
FUSGS
}

\section{Inventory of Neoproterozoic and Paleozoic strata in Sonora, Mexico}

By John H. Stewart ${ }^{1}$ and Forrest G. Poole 2

Open-File Report 02-97

Also available at http://geopubs.wr.usgs.gov/open-file/of02-97

2002

This report is preliminary and has not been reviewed for conformity with U.S. Geological Survey editorial standards or with the North American Stratigraphic Code. Any use of trade, firm, or product names is for descriptive purposes only and does not imply endorsement by the U.S. Government.

\section{U.S. DEPARTMENT OF THE INTERIOR}

\section{U.S. GEOLOGICAL SURVEY}

1 U.S. Geological Survey, 345 Middlefield Road, Menlo Park, CA, 94025

2 U.S. Geological Survey, Denver Federal Center, Box 25046, Denver, Colorado, 80225 


\section{CONTENTS}

Introduction

Rocks that appear to have been erroneously mapped as Paleozoic

Problematic strata in southern Sonora

Index of Neoproterozoic and Paleozoic localities

References cited

\section{FIGURES}

1. Index map showing location of figure 2 and of localities of Paleozoic or possible Paleozoic strata in Sonora outside of figure 2.

2. Index of localities described in text. See introduction for explanation.

3. Distribution of Neoproterozoic strata older than Cordilleran miogeocline. About 1,000 to $750 \mathrm{Ma}$.

4. Distribution of Neoproterozoic strata in lower part of Cordilleran miogeocline About 750 to $540 \mathrm{Ma}$.

5. Distribution of Cambrian strata in Sonora

6. Distribution of Ordovician strata

7. Distribution of Silurian strata

8. Distribution of Devonian strata

9. Distribution of Mississippian strata

10. Distritution of Pennsylvanian strata

11. Distribution of Permian strata 


\section{INTRODUCTION}

This compilation is an inventory of all known outcrops of Neoproterozoic and Paleozoic strata in Sonora, Mexico. We have not attempted an interpretation of the regional stratigraphic or structural setting of the strata. Brief summaries of the stratigraphic setting of the Sonora rocks are given in Poole and Hayes (1971), Rangin (1978), Stewart and others (1984, 1990), and Poole and Madrid (1986; 1988b). More specific information on the setting of strata of specific ages are given by Stewart and others (2002) for the Neoproterozoic and Cambrian; by Poole and others (1995a) for Ordovician shelf strata; by Poole and others (1995b) for Ordovician deep-water openbasin strata; by Poole and others (1997, 1998, 2000a) for Silurian strata; and by

Poole and others (2000a) for Mississippian strata. Other reports that discuss regional aspects of Paleozoic stratigraphy include López-Ramos (1982), Peiffer-Rangin, (1979, 1988), Pérez-Ramos (1992), and Stewart and others (1997, 1999a).

Structurally, the major Paleozoic feature of Sonora is the Sonora allochthon, consisting of deep-water (eugeoclinal) strata emplaced in the Permian over shelf (miogeoclinal) deposits (Poole and others, 1995a,b; Poole and Perry, 1997; 1998). The emplacement structure is generally considered to be a major Permian continental margin thrust fault that emplaced the deep-water rocks northward over shelf (miogeoclinal) deposits. An alternate interpretation has been presented by Stewart and others (2002). He proposed that the emplacement of the Sonora allochthon was along a major Permian transpressional structure that was primarily a strike-slip fault with only a minor thrust component .

The Mojave-Sonora megashear has been proposed to disrupt Neoproterozoic and Paleozoic trends in Sonora. This feature is a hypothetical, left-lateral, northwest-striking fault extending across northern Sonora and the southwestern United States (Silver and Anderson, 1974; Anderson and Schmidt, 1983). It is proposed to have Jurassic displacements of about 700-800 km. Current opinion is mixed concerning whether the Mojave-Sonora megashear exists (see discussions and references in Stewart and others, 1990; 1999a).

The inventory presented here is the product of a search of the literature for described Neoproterozoic and Paleozoic localities and our examination of a large number of the outcrops in the field. The individual localities are described by reference letters and numbers, locality name, latitude and longitude, a brief text on the stratigraphy of the strata, and references. Figure 1 is an index showing the location of Sonora and the location of figure 2. The location of a few localites that are outside of figure 2 are also shown on figure 1. We also include a separate description of localities that have been erroneously reported, on the based of our field examinations, to contain Neoproterozoic and Paleozoic rocks. We include a brief description of problematic strata in southern Sonora that have been described as Paleozoic, but may be at least in part Mesozoic. Figures 3-11 show the distribution of Neoproterozoic, Cambrian, Ordovician, Silurian, Devonian, Mississippian, Pennsylvanian, and Permian strata in Sonora.

The reference letters indicate the specific $1^{\circ}$ by $2^{\circ}$ quadrangle, and the number indicates the specific site within that quadrangle. Not all numbers are used. The code for the $1^{\circ}$ by $2^{\circ}$ quadrangles is as follows:

AP, Agua Prieta

$\mathrm{CB}$, Caborca

$\mathrm{CN}$, Cananea,

$\mathrm{H}$, Hermosillo (H12-8)

IA, Isla Angel de la Guarda (H12-7)

M, Madera (H12-9) 
ME, Mexicalli (I-11-12)

NG, Nogales

NZ, Nacozari

P, Puerto Peñasco (H12-1)

SL, Sierra Libre, H12-11

$\mathrm{T}$, Tecoripa (H12-12)

\section{ROCKS THAT APPEAR TO HAVE BEEN ERRONEOUSLY MAPPED AS PALEOZOIC}

Nacozari, centered on lat $30^{\circ} 29^{\prime} \mathrm{N}$., long $109^{\circ} 44^{\prime} \mathrm{W}$., shown as Paleozoic on INEGI (Instituto Nacional de Estadistica Geografía e Informatica) Nacozari $1^{\circ}$ by $2^{\circ}$ quadrangle (H-12-6). Lithologically variable assemblage of calc-silicate hornfels and fine- to very- fine-grained quartzite associated with possible volcaniclastic and tuffaceous rocks, probably Mesozoic.

Sierra Sombreretillo, centered on lat $30^{\circ} 38^{\prime}$ N., long $109^{\circ} 39^{\prime} \mathrm{W}$., shown as Paleozoic on INEGI Nacozari $1^{\circ}$ by $2^{\circ}$ quadrangle (H-12-6). Sandstone and siltstone containing silicified wood in a volcanic succession of Cenozoic age.

Las Peñitas area, Sierra Caracahui, (La Julia unit of Mendoza-Córdova and MinjaresRivera, 1989), centered on about lat $30^{\circ} 15^{\prime} \mathrm{N}$., long $110^{\circ} 53^{\prime} \mathrm{W}$. Thin layers of siliciclastic arenites in siltstone and metavolcanic rocks, probable Mesozoic age. One outcrop is a Tertiary rhyolite plug.

Estación Llano, lat $30^{\circ} 21^{\prime} \mathrm{N}$., long $111^{\circ} 08^{\prime} \mathrm{W}$. Siliciclastic arenite, siltstone, and metavolcanic rocks of probable Mesozoic age.

Cerro el Picacho, Arispe area, centered on lat $30^{\circ} 25^{\prime}$ N., long $110^{\circ} 07^{\prime}$ N. Shown as Paleozoic on Mapa Geológico Minero de Sonora (Consejo de Recursos Minerales, 1994). Thick succession of carbonate and siliciclastic rocks considered to be Mesozoic in age.

Lomas Tamichopa, lat $30^{\circ} 17^{\prime} \mathrm{N}$., long $108^{\circ} 50^{\prime} \mathrm{W}$. Shown as Paleozoic on INEGI Nacozari $1^{\circ}$ by $2^{\circ}$ quadrangle $(\mathrm{H}-12-6)$. Silicified Tertiary volcanic rock.

Cerro de Oro. A small arrea of fossiliferous carbonate rocks in the Cerro de Oro area (1.3 $\mathrm{km}$ northeast of Cerro El Cielo, $1.5 \mathrm{~km}$ northeast of Cerro Copete), $29^{\circ} 37.3^{\prime} \mathrm{N}$., long $110^{\circ} 37.0^{\prime} \mathrm{W}$, contains a brachiopod fauna reported by Radelli (1996) to be Permian. Fossils collected at the same locality by Stewart and R. Amaya-Martínez in 1997 were sent to R.B. Blodgett who indicates (2001, written commun.) that the fossils are Cretaceous, definitely not Permian. He further notes that the fossils are closely related to those collected by C. González-León, probably from the same locality, and identified by E. Owens (1988, written commun.) as Cyclothyris indi (Ager), Colinella mullerriedi (Imlayi), Gemmarcula arizonensis Cooper, and Waconella wacoensis. Owens indicates a Cretaceous age for these fossils.

Cerro Caloso, $16 \mathrm{~km}$ south of Hermosillo: centered at lat. $28^{\circ} 57^{\prime} \mathrm{N}$., long. $110^{\circ} 56^{\prime} \mathrm{W}$. Mapped as Paleozoic on 1:250,000-scale INEGI geologic map of Sierra Libre, but apparently consists entirely of Upper Triassic and Lower Jurassic? Barranca Group with graphite, and a gypsum layer (Yeso mine on 1:50,000-scale topographic map H12D51) (Martín Valencia, oral commun., 1997).

El Jaralito area, centered on lat $29^{\circ} 39 \mathrm{~N}$., long $110^{\circ} 16^{\prime} \mathrm{W}$. Mapped as Paleozoic on INEGI 1:250,000-scale Hermosillo geologic map and as Paleozoic (?) by Peabody (1979). Consists of marble, calc-silicate hornfels, pelitic schist, hornfels, metaconglomerate, and quartzite (Peabody, 1979). Field examination by Stewart and R. AmayaMartínez in 1996 indicates that the succession does not resemble Neoproterozoic or Paleozoic strata elsewhere in the region, and that it is probably Mesozoic in age.

Cerro Los Taraices, about $20 \mathrm{~km}$ east southeast of Moctezuma, about $9 \mathrm{~km}$ southeast of Cerro Tonibabi, centered on about lat $29^{\circ} 45^{\prime} \mathrm{N}$, long $109^{\circ} 30^{\prime} \mathrm{W}$. Shown on INEGI 
1:250,000-scale map as Paleozoic. Consists of limestone, calc-silicate hornfels, and metasiltstone. The limestone locally contains abundant poorly preserved shelly material including brachiopods, oysters (?), and orbitolinas and the succession is considered Cretaceous in age (Roldán-Quintana, 1994).

\section{PROBLEMATIC STRATA IN SOUTHERN SONORA}

Paleozoic, or possible Paleozoic strata, south of about lat $28^{\circ} 15^{\prime} \mathrm{N}$. in Sonora are shown on figure 1, but are not given locality numbers or described elsewhere in the text. Within this large region, no definite Paleozoic strata have been identified, although Dumble (1900), Angermann (1904), and King (1939) mapped and (or) described several localities that they considered to contain Paleozoic rocks. These strata consist of quartzite, quartzitic sandstone, slate, micaceous phyllite, and limestone. A few localities contain brachiopods, corals, and pelmatozoan detritus. In outcrops near El Trigo (lat $27^{\circ} 311^{\prime} \mathrm{N}$., long $109^{\circ} 06^{\prime} \mathrm{W}$.), Angermann (1904) indicates that a Spirifer was found, suggesting a late Paleozoic, possibly Permian age (King, 1939). In the El Trigo region, Triassic strata have been identified (see summary in Stewart and others, 1997), and possibly some or all of the so-called Paleozoic strata are Triassic. Poole and Amaya-Martínez (unpublished field work, 1996) examined some of the so-called Paleozoic strata in southern Sonora and considered them to be possibly Mesozoic. Nevertheless, a Paleozoic age for these strata is possible. Paleozoic strata commonly are associated with Triassic strata in central Sonora, and a similar relation could exist in southern Sonora. Finally, Paleozoic strata have been identified south of Sonora in northern Sinaloa (Gastil and others, 1991; Poole and Perry, 1998; Poole, W.R. Page, and A.G. Harris, quoted in Stewart and others, 1999b) and this region containing Paleozoic rocks could extend into southern Sonora.

Rocks mapped as Paleozoic marble, schist, and phyllite are shown in southernmost Sonora (Fig. 1) on the CESUES (Centro de Estudios Superiores del Estado de Sonora) 1:500,000-scale map of Sonora (Fernández-Aguirre and others, 1993). We have no further information on these rocks.

\section{INDEX OF NEOPROTEROZOIC AND PALEOZOIC LOCALITIES}

AP-2, Cerro La Morita: lat $31^{\circ} 12^{\prime} 35^{\prime \prime}$ N. to lat $31^{\circ} 16^{\prime} 20^{\prime \prime N}$., long $109^{\circ} 47^{\prime} 20^{\prime \prime W}$. to long $109^{\circ} 50^{\prime} 40^{\prime \prime W}$. Peiffer-Rangin (1988) recognized $120 \mathrm{~m}$ of Desmoinesian strata (incomplete), $260 \mathrm{~m}$ of Missourian strata (incomplete), and $90 \mathrm{~m}$ of Lower Permian strata.

AP-3, Cerro Cabullona: lat $31^{\circ} 05.2^{\prime} \mathrm{N}$. to lat $31^{\circ} 06.7 \mathrm{~N}$., long $109^{\circ} 30.9^{\prime} \mathrm{W}$. to long 109 33.0W. Taliaferro (1933) and Viveros-Martínez (1965). Observations of Stewart and R. Amaya-Martínez (field studies, 1996), at lat $31^{\circ} 07.1 \mathrm{~N}$., long $109^{\circ} 33.9^{\prime} \mathrm{W}$. indicate a Precambrian porphyritic granite unconformably overlain by the Middle Cambrian Bolsa Quartzite. The Bolsa consists of fine- to medium-grained quartzite and minor conglomerate with clasts of quartz and quartzite(?) as large as $2 \mathrm{~cm}$. ViverosMartínez (1965) reported $20 \mathrm{~m}$ of Bolsa Quartzite, more than $259 \mathrm{~m}$ of Devonian Martin (?) Formation, and more than 192 m of Mississippian Escabrosa Limestone (?).

AP-4, Loma Blanca: lat $31^{\circ} 08^{\prime} \mathrm{N}$., long $110^{\circ} 09^{\prime} \mathrm{W}$. Shown as Paleozoic carbonate strata in Rangin (1977) and in INEGI Agua Prieta (H-12-3) 1:250,000-scale geologic map. Not examined during present study.

AP-5, Sierra Guadalupe: lat. $31^{\circ} 18^{\prime}$ N., long $109^{\circ} 07^{\prime} \mathrm{W}$. Paleozoic rocks reported by Rangin (1977) and Peiffer-Rangin (1988). Not examined during present study. 
CB-1, Cerro Gamuza: lat $30^{\circ} 33^{\prime} \mathrm{N}$ to lat $30^{\circ} 07^{\prime} \mathrm{N}$., long $112^{\circ} 06^{\prime} \mathrm{W}$. to long $112^{\circ} 08^{\prime} \mathrm{W}$. Stratigraphic succession (Longoria, 1981; Longoria and González, 1979; Stewart and others, 1984) consists, in ascending order, of: Pitiquito Quartzite, 89 m; Gamuza Formation, thickness unknown; Tecolote Quartzite (?); and possibly stratigraphically higher units. Stromatolites in the Gamuza Formation were described by Weber and others (1979). Other papers describing or summarizing stromatolite occurrences in this or other areas of the Caborca region are Cevallos-Ferríz (1981a, 1981b), CevallosFerríz and Roldán-Quintana (1984), Cevallos-Ferríz and Weber (1980), CevallosFerríz and others (1981, 1982, 1988), Weber and others (1979), and McMenamin and others (1994).

CB-2, Cerro El Arpa: lat $30^{\circ} 28 \mathrm{~N}$. to lat $30^{\circ} 32^{\prime} \mathrm{N}$., long $112^{\circ} 08 \mathrm{~W}$. to $112^{\circ} 09^{\prime} \mathrm{W}$. Neoproterozoic stratigraphic succession (Longoria, 1981; Longoria and González, 1979; Stewart and others, 1984) rests unconformably on 1,110 Ma Aibo Granite (Anderson and Silver, 1979) and consists, in ascending order, of: El Arpa Formation, $190 \mathrm{~m}$; Caborca Formation, $105 \mathrm{~m}$; Clemente Formation, faulted and incomplete, 101 m; Pitiquito Formation, 110 m; Gamuza Formation, 80? m; and Papalote Formation, $188 \mathrm{~m}$, top not exposed.

CB-3, Cerro Aguituni-Cerro San Clemente (Sierra La Verruga): lat $30^{\circ} 14^{\prime} \mathrm{N}$ to lat $30^{\circ} 17^{\prime} \mathrm{N}$., long $112^{\circ} 06^{\prime} \mathrm{W}$. to long $112^{\circ} 12^{\prime} \mathrm{W}$. Stratigraphic section (Eells, 1972; Stewart and others, 1984) consists, in ascending order, of: Pitiquito Quartzite, thickness unknown; Gamuza Formation, thickness unknown; Papalote Formation; La Ciénega Formation, thickness unknown; Puerto Blanco Formation, 400 m, incomplete. Stromatolites occur in the Gamuza Formation (Cevallos-Ferríz and others, 1981).

CB-4, Cerro Calaveras: lat $30^{\circ} 14^{\prime} \mathrm{N}$. to lat $30^{\circ} 17^{\prime} \mathrm{N}$., long $112^{\circ} 04^{\prime} \mathrm{W}$. to long $112^{\circ} 07 \mathrm{~W}$. Stratigraphic succession (Eells, 1972; Stewart and others, 1984) consists, in ascending order, of: Caborca Formation, $150 \mathrm{~m}$, base not exposed; Clemente Formation, 116 m; Pitiquito Quartzite, 30 m; Gamuza Formation, 110 m; Papalote Formation, 520 m; Tecolote Quartzite, 70 m; La Ciénega Formation, 180 m; Puerto Blanco Formation, 546 m; Proveedora Quartzite, 224 m; Buelna, 68 m; Cerro Prieto Formation, thickness unknown; Arrojos Formation, thickness unknown; and Tren Formation, $100 \mathrm{~m}$, top not exposed. Stromatolites (Cevallos-Ferríz and others, 1981) occur in the Gamuza Formation. Cloudiniid (small shelly fossils) are present in the La Ciénega Formation (McMenamin, 1985; Hagadorn, 2000). Stromatolites occur in the Gamuza Formation (Cevallos-Ferríz and others, 1981; McMenamin and others, 1994) and the Puerto Blanco Formation contains archeocyathids and trace fossils (Debrenne and others, 1989).

CB-5, Cerros de la Ciénega: lat $30^{\circ} 07^{\prime} \mathrm{N}$. to lat $30^{\circ} 13^{\prime} \mathrm{N}$., long $111^{\circ} 59^{\prime} \mathrm{W}$. to long $112^{\circ} 05^{\prime} \mathrm{W}$. Stratigraphic section (Eells, 1972; Stewart and others, 1984) consists, in ascending order, of: El Arpa Formation and Caborca Formation, undivided, 503 m; Clemente Formation, 116 m; Pitiquito Formation, 208 m; Gamuza, Papalote, La Ciénega, and Puerto Blanco Formations, and Proveedora Quartzite, thicknesses unknown; Buelna Formation, 112 m; Cerro Prieto Formation, 88 m; and Arrojos Formation, $201 \mathrm{~m}$, top not exposed. Stromatolites occur in the Gamuza Formation (Cevallos-Ferríz and others, 1981).

CB-6, Cerro Pozo Serna: lat $30^{\circ} 08^{\prime}$ N. to lat $30^{\circ} 11^{\prime}$ N., long $112^{\circ} 10^{\prime} \mathrm{W}$. to long $112^{\circ} 12^{\prime} \mathrm{W}$. Little studied outcrops of Neoproterozoic and Lower Cambrian rocks considered to correlate with the Neoproterozoic and Cambrian strata at Caborca 
(Morales-Montaño and Cota-Reyna, 1990; Calmus and others, 1997; Lucas and others, 1999). Stewart and others (1984) reported presence of Buelna Formation in this area.

CB-7A, Sierra del Viejo, northern part: lat $30^{\circ} 11^{\prime} \mathrm{N}$. to lat $30^{\circ} 17^{\prime} \mathrm{N}$., long $112^{\circ} 16^{\prime} \mathrm{W}$. to long $112^{\circ} 21^{\prime} \mathrm{W}$. Stratigraphic succession, according to Pelayo-Ledezma and Salcido-Reyna (1985), consists, in ascending order, of: unit I, $305 \mathrm{~m}$, correlative to the El Arpa and Caborca Formations, undivided; unit II, $150 \mathrm{~m}$, correlative to the Clemente and Pitiquito Quartzite, undivided; unit III, $200 \mathrm{~m}$, correlative to the Gamuza Formation; unit IV, 350 m, correlative to the Papalote Formation; and unit V, 200 m, correlative to the Tecolote Quartzite. The lower $70 \mathrm{~m}$ of unit V is mostly dolomite that possibly correlates with the uppermost part of the Papalote Formation. Units III and IV, according to Pelayo-Ledezma and Salcido-Reyna (1985), contain the stromatolites Conophyton and locally Jacutophyton. The presence of stromatolites in Sierra del Viejo is also mentioned by Cevallos-Ferríz and others (1981). The presence of Conophyton in unit IV (strata correlative of the Papalote Formation) is unusual because this stromatolite has not been recognized in the Papalote Formation elsewhere. Additional work is necessary to confirm the stratigraphic position of these stromatolites.

CB-7B, Sierra del Viejo, southern part: lat $30^{\circ} 11^{\prime} \mathrm{N}$. to lat $30^{\circ} 25^{\prime} \mathrm{N}$., long $112^{\circ} 16^{\prime} \mathrm{W}$. to long $112^{\circ} 25^{\prime} \mathrm{W}$. The stratigraphic section, according to Pelayo-Ledezma and Salcido-Reyna (1985), consists, in ascending order, of: unit II' (200 m) correlative with the Pitiquito Quartzite; unit III' $(240 \mathrm{~m})$ correlative with the Gamuza Formation; unit IV'(300 m) correlative with the Tecolote Formation; Puerto Blanca Formation, 50 m, probably too thin; Proveedora Quartzite, 60 m; Buelna Formation, 101-121 m; and Cerro Prieto Formation, $70 \mathrm{~m}$, incomplete. Unit III' contains stromatolites (PelayoLedezma and Salcido-Reyna, 1985; Cevallos and others, 1981). Rocks comparable to the La Ciénega Formation were not recognized by Pelayo-Ledezma and Salcido-Reyna (1985). The Lower Cambrian Proveedora Quartzite is recognized in the southernmost Sierra del Viejo (Stewart and others (1984).

CB-8, Cerros de Los Arrojos: lat 30³7.2'N., long $112^{\circ} 17.7^{\prime} \mathrm{W}$. Stratigraphic succession (Cooper and others, 1952) consists, in ascending order, of: Proveedora Quartzite, thickness not determined; Buelna Formation, thickness not determined; Cerro Prieto Formation, about 91 m; Arrojos Formation, 189? m; and Tren Formation, 531 $\mathrm{m}$, top not exposed. The Buelna, Arrojos, and Tren Formations contain trilobites and other fossils (Lochman, 1948, 1953; Cooper and others, 1952; McMenamin and others, 1994).

CB-9, Cerro de la Lista Blanca: $30^{\circ} 37.5^{\prime} \mathrm{N}$., long $112^{\circ} 15^{\prime} \mathrm{W}$. Marble and metadolomite containing poorly preserved Middle Cambrian trilobites indicative of the Tren Formation (Cooper and others, 1952).

CB-10, Cerros de la Proveedora (Proveedora Hills): $30^{\circ} 41^{\prime} \mathrm{N}$. to $30^{\circ} 43^{\prime} \mathrm{N}$., long $112^{\circ} 15^{\prime} \mathrm{W}$. to long $112^{\circ} 16^{\prime} \mathrm{W}$. The stratigraphic succession (Cooper and others, 1952; 1954) consists, in ascending order, of: Puerto Blanca Formation, 293 m, base not exposed; Proveedora Quartzite, 223 m; Buelna Formation, 101 to $121 \mathrm{~m}$; Cerro Prieto Formation, 100 m; Arrojos Formation, 310 m; and Tren Formation, 490 m, top not exposed. Isolated exposures of the Puerto Blanca Formation west of the main outcrops contain archeocyathids (Cooper and others 1952; Debrenne, 1987; Debrenne and others, 1989). Higher in the stratigraphic succession, trilobites and other fossils are present in the Puerto Blanco Formation, Buelna Formation, Cerro Prieto Formation, and Arrojos Formation (Lochman, 1948; 1953; Cooper and others, 1952; McMenamin 
and others, 1994). Studies of the paleoenvironments of the Cambrian strata of the Proveedora Hills and of the Caborca region are given by Rivera-Carranco (1988) and Armella and Cabaleri (1990).

Correlation of strata in Proveedora Hills and elsewhere in Caborca area with strata in the western United States and Canada were given by Eells (1972), Fritz (1975), Palmer (1981), and Stewart and others (1984).

CB-11, Cerro Cañedo: lat $30^{\circ} 41.8^{\prime} \mathrm{N}$., long $112^{\circ} 7.5^{\prime} \mathrm{W}$. Cooper and others (1952) reported Early Cambrian fossils from this locality that are indicative of the Puerto Blanco Formation. Weber and others (1979, p. 13) reported archeocyathids.

CB-12, Cerros de Buelna (Buelna Hills): lat $30^{\circ} 45^{\prime} \mathrm{N}$., long $112^{\circ} 18^{\prime} \mathrm{N}$. The stratigraphic succession (Cooper and others, 1952) consists, in ascending order, of: Proveedora Quartzite about 91 m, base not exposed; Buelna Formation, 85 m; Cerro Prieto Formation, thickness not determined, top not exposed. The Buelna Formation contains trilobites and other fossils (Cooper and others, 1952; McMenamin and others, 1994).

CB-13, Cerros de los Difuntos: This name does not appear on the 1980, 1;50,000-scale topographic map of the El Sahuaro (H12A56) quadrangle nor on 1;250,000-scale topographic maps of the area. Cooper and others (1952) described the locality as "about 14 miles northwest of Caborca". We have not tried to find this locality in the field, but presume it is located at about lat $30^{\circ} 53^{\prime} \mathrm{N}$., long $112^{\circ} 19^{\prime} \mathrm{W}$. Outcrop consists of a small group of hills containing trilobites and archeocyathids (Cooper and others, 1952; Debrenne, 1987; Debrenne and others, 1989; McMenamin and others, 1994). The trilobites are indicative of the Buelna Formation (Cooper and others, 1952), but archeocyathids are not found at this stratigraphic position elsewhere in Sonora or in correlative rocks in the western United States. Although we have not visited the locality, we suspect that the rocks containing the trilobites and archeocyathids may have been juxtaposed by faulting. Cooper and others (1952) also recognized the Cerro Prieto Formation, apparently the Arrojos Formation, and the Tren Formation in the Cerros de los Difuntos.

CB-14, El Bísani: lat $30^{\circ} 40^{\prime} 30^{\prime \prime} \mathrm{N}$. to lat $30^{\circ} 42^{\prime} 30^{\prime} \mathrm{N}$., long $112^{\circ} 23^{\prime} 00^{\prime} \mathrm{W}$. to long $112^{\circ} 24^{\prime} 30^{\prime \prime W}$. Ordovician, Silurian, Devonian, and Mississippian strata form small hillocks in a broad alluvial plain. First described by Cooper and Arellano (1946) and later by Easton (1958), Brunner (1975, 1976), Armstrong and others (1981), and Poole and others (1995a, 1997, 1998). Poole (references cited previously and unpublished field work) and A.J. Boucot (1974, written commun.) have done studies in the area. Their lithostratigraphic and biostratigraphic studies indicate the presence of discontinuous outcrops of Ordovician to Mississippian carbonate shelf/platform rocks in the Rancho El Bísani area located about $22 \mathrm{~km}$ west of Caborca, Sonora. Ordovician and Silurian rocks are dated by conodonts and Devonian and Mississippian rocks are dated by conodonts, corals, gastropods, and brachiopods. The late Middle Devonian (Givetian) brachiopod genus Stringocephalus was found by A.J. Boucot (1993, written commun.) and stringocephalids were recognized by Poole (1999, unpubl. data) in the northwestern part of the Bísani area. In the same outcrop area, the early Late Devonian (Frasnian) gastropod genus Orecopia was found by G.A. Cooper (1975, written commun. to Boucot). Several Late Devonian coral genera (Smithiphyllum, Tabulophyllum, Amphipora) and massive stromatoporoids were identified by W. J. Oliver, Jr., from Cooper's Orecopia collection. The corals are consistent with the Frasnian age indicated by Orecopia, according to Boucot (1993, written commun.). The Mississippian strata consist of both Lower and Upper Mississippian fossiliferous 
limestones that are dated by conodonts and foraminifera (Brunner, 1976; Poole, unpubl. data).

CB-15, El Antimonio: lat $30^{\circ} 45^{\prime} 30^{\prime \prime}$ N. to lat $30^{\circ} 46^{\prime} 30^{\prime \prime} \mathrm{N}$., long $112^{\circ} 34^{\prime} 10^{\prime \prime} \mathrm{W}$. to long $112^{\circ} 36^{\prime} 15^{\prime \prime W}$. Monos Formation of Late Permian age is described by Cooper and Arellano (1946), Cooper and others (1953), Cooper, 1965, Guiza and White (1949), White and Guiza (1950), and González-León (1980), and Wardlaw (1981), Lucas and others (1997), González-Léon (1997), and Lucas and Estep (1999).

CB-17, 8.5 km northwest of Caborca: lat $30^{\circ} 46^{\prime} \mathrm{N}$., long $112^{\circ} 13^{\prime} \mathrm{W}$. Small hill containing Neoproterozoic dolomite, thrust over Upper Cretaceous rocks (César Jacques-Ayala, 1995, written commun.). Dolomite is presumably correlative to Neoproterozoic dolomite near Caborca.

CB-18, Cerrito de la Milla and Cerro de la Máquina: lat $30^{\circ} 43.0^{\prime} \mathrm{N}$. to lat. $30^{\circ} 43.5^{\prime} \mathrm{N}$., long $112^{\circ} 8.1^{\prime} \mathrm{W}$. to $112^{\circ} 9.0^{\prime} \mathrm{W}$. Small outcrops within and adjacent to town of Caborca. Gamuza Formation contains the stromatolites Conophyton Jacutophyton, and Platella (Weber and others, 1979; Weber and Cevallos-Ferríz, 1980).

CB-19, Cerro Prieto: lat $30^{\circ} 41.5^{\prime} \mathrm{N}$. , long $112^{\circ} 10.2^{\prime} \mathrm{W}$. Stratigraphic succession (Cooper and others, 1952) consists, in ascending order, of: Proveedora Quartzite, 44 m, base not exposed; Buelna Formation, 84 m; and Cerro Prieto Formation , 81 m, top not exposed. Trilobites and other fossils are present in the Buelna Formation (Cooper and others, 1952; McMenamin and others, 1994).

CN-4, Cerro Los Changos: lat $30^{\circ} 08.3^{\prime} \mathrm{N}$. to $30^{\circ} 09.5 \mathrm{~N}$., long $110^{\circ} 31^{\prime} \mathrm{W}$. to $110^{\circ} 31.2^{\prime} \mathrm{W}$. Consists of fine- to medium-grained quartzite defined as the Los Changos Quartzite (Rodríguez-Castañeda, 1984, 1988), here assigned to the Las Víboras Group. Locally includes coarse-grained quartzite and conglomerate with clasts of white quartz. These rocks lie adjacent to Precambrian crystalline basement rocks and are lithologically similar to rocks in the Neoproterozoic El Tápiro Formation of the Las Víboras Group, with which the Los Changos Quartzite is correlated. Other parts of the unit mapped as the Los Changos Quartzite are associated with volcaniclastic rocks and could be Mesozoic in age, or alternately the volcaniclastic rocks could be in different structural blocks and unrelated to the Los Changos Quartzite.

CN-5, Sierra Rajón: lat $30^{\circ} 24^{\prime}$ N. to lat $30^{\circ} 27^{\prime}$ N., long $111^{\circ} 55^{\prime} \mathrm{W}$. to long $111^{\circ} 58^{\prime} \mathrm{W}$. Neoproterozoic and Lower Cambrian rocks are about 2,560 $\mathrm{m}$ thick and rest unconformably on a 1,400 Ma Precambrian crystalline basement (Stewart and others, 1984; Stewart, 1984). The stratigraphy, in ascending order, is: El Arpa Formation, $89.7 \mathrm{~m}$; Caborca Formation, $126.6 \mathrm{~m}$; Clemente Formation, $210.3 \mathrm{~m}$; Pitiquito Quartzite, 77 m; Gamuza Formation, 135 m; Papalote Formation, 404.5 m; Tecolote Quartzite, 168.5 m; La Ciénega Formation, 178 m; Puerto Blanco Formation, 717 m; Proveedora Quartzite, $201 \mathrm{~m}$; Buelna Formation, $77.5 \mathrm{~m}$; Cerro Prieto Formation, 82 $\mathrm{m}$; and Arrojos Formation, $93 \mathrm{~m}$ (incomplete). The Clemente Formation has been reported (McMenamin and others, 1992; McMenamin, 1996) to contain a Neoproterozoic Ediacaran biota as well as trace fossils and enigmatic fossils. Waggoner (1999) has questioned whether these are fossils. The Gamuza Formation contains large conical stromatolites that are mostly Conophyton (Stewart and others, 1984; McMenamin, 1982; McMenamin and others, 1994). La Ciénega Formation contains cloudiniid (small shelly fossils) (McMenamin and others, 1983; Signor and others, 1983; McMenamin 1985; McMenamin and others, 1994; Hagadorn and Fedo, 
2000). The Puerto Blanco Formation contains trilobites (McMenamin, 1983, 1987; McMenamin and others, 1994), archeocyathids (Debrenne and others, 1989), brachiopods (McMenamin, 1987; McMenamin and others, 1994), and rare other fossils (McMenamin, 1992), McMenamin and others, 1994). Chemostratigraphic studies (Rowland and others, 1993) of the Sierra Rajón section support, in general, previous correlations (Stewart and others, 1984) of stratigraphic units from Sierra Rajón to the western United States. Sierra Rajón has also been the site of paleomagnetic studies on basaltic rocks in the Puerto Blanco Formation (Barr and Kirschvink, 1983)

CN-6, Sierra La Víbora (also called Cerro Pitiquito, includes Cerros Caborca of Weber and others, 1979): lat $30^{\circ} 32 ' \mathrm{~N}$. to lat $30^{\circ} 40^{\prime} \mathrm{N}$., long $111^{\circ} 57^{\prime} \mathrm{W}$. to long $112^{\circ} 03^{\prime} \mathrm{W}$. DeJong and others (1988) mapped extensive outcrops of Neoproterozoic and Lower Cambrian strata (El Arpa Formation, Caborca Formation, Clemente Formation, Pitiquito Formation, Gamuza Formation, Papalote Formation, Tecolote Quartzite, La Ciénega Formation, and Puerto Blanco Formation). Other references: Longoria and Perez (1978) and Mendoza (1981). Cloudiniids (small shelly fossils have been described from the La Ciénega Formation by McMenamin (1985; Hagadorn, 2000); and large stromatolites (Conophyton, Jacutophyton, and Platella) by Weber and others (1979) and Weber and Cevallos-Ferríz (1980).

CN-7, Cerro Clemente-Cerro Llano Verde: lat $30^{\circ} 15^{\prime} \mathrm{N}$. to lat $30^{\circ} 21^{\prime} \mathrm{N}$., long $111^{\circ} 52^{\prime} \mathrm{W}$. to long $112^{\circ} 02^{\prime} \mathrm{W}$. Stratigraphic succession (Westerfield, 1988) consists, in ascending order, of: El Arpa Formation, 0-18 m; Caborca Formation, 106 m; Clemente Formation, 188 m; Pitiquito Formation, 48 m; Gamuza Formation, 140 m; Papalote Formation, 390 m; Tecolote Formation, 130 m; La Ciénega Formation, 143 m; Puerto Blanco Formation, 625 m; Proveedora Formation, 225 m; Buelna Formation, 79.5 m; and Cerro Prieto Formation, 100 m, top not exposed. Stromatolites are present in the Gamuza Formation (Cevallos-Ferríz and others, 1981; Westerfield, 1988). Cloudiniids (small shelly fossils) are present in the La Ciénega Formation (McMenamin, 1985; Hagadorn, 2000). Archeocyathids and trace fossils are present in the Puerto Blanco Formation (Westerfield, 1988; Debrenne and others, 1989). Trilobite fragments and other fossil debris are present in the Buelna Formation (Westerfield, 1988).

CN-8, Cananea: lat $30^{\circ} 58^{\prime} 45^{\prime \prime} \mathrm{N}$. to lat $31^{\circ} 01^{\prime} 15^{\prime \prime} \mathrm{N}$., long $110^{\circ} 20^{\prime} 10^{\prime \prime} \mathrm{W}$. to long $110^{\circ} 23^{\prime} 50^{\prime \prime}$. Emmons (1910), Mitchell (1928), Valentine (1936), Mulchay and Velasco (1954), Velasco (1966), Anderson and Silver (1977), Einaudi (1982), Meinert (1980, 1982), and Bushnell (1988). The oldest Paleozoic unit is the Capote Quartzite of Valentine (1936) which is at least $140 \mathrm{~m}$ thick (Mulchay and Velasco, 1954), and rests unconformably on 1,440 \pm 15 Ma granitic rocks (Anderson and Silver, 1977; Einaudi, 1982). The Capote Quartzite is correlated with the Bolsa Quartzite of Arizona (Mulchay and Velasco, 1954) and is apparently conformably overlain by the Esperanza Limestone of Mulchay and Velasco (1954). The Esperanza Limestone is about $90 \mathrm{~m}$ thick and consists of highly altered and mineralized thin-bedded limestone. It is correlated with the Cambrian Abrigo Limestone of Arizona by Mulchay and Velasco (1954). Above the Esperanza Limestone is a unit termed the "Crystalline Limestone" or "Crystalline formation" by Mulchay and Velasco (1954) that may be Devonian and/or Mississippian in age.

CN-9, Cerro El Vigía: centered on lat $30^{\circ} 07^{\prime}$ N., long $110^{\circ} 12.5^{\prime} \mathrm{W}$. Martínez-García and Soots-López (1994) mapped and described about $500 \mathrm{~m}$ of sandstone, quartzite, and siltstone that they assigned to the Paleozoic(?). They divided these rocks into two units, a lower unit of reddish-brown, cross-stratified and thin-bedded arkosic 
sandstone and siltstone locally containing casts of salt crystals, and an upper unit of quartzite. The lower unit is lithologically similar to the El Alamo Formation of the Las Víboras Group, and we feel confident in assigning it to the El Alamo Formation. We are unsure of the assignment of the upper unit. It may be part of the El Alamo Formation, but we also observed in the Cerro El Vigía area a yellow-gray quartzite unit containing siliceous nodules. Such quartzite is typical of the El Tápiro Formation of the Las Víboras Group, and we here correlate this quartzite unit with the El Tápiro Formation. The quartzite unit may be the upper unit of Martínez-García and SootsLópez (1994), but, if so, it must be separated from the El Alamo Formation by a fault. The El Tápiro Formation underlies the El Alamo Formation in the Cerro de Oro area where these two formations are defined, and does not overlie the El Alamo Formation as described by Martínez-García and Soots-López (1994).

CN-10, Sierra El Jucaral: lat $30^{\circ} 01.5^{\prime} \mathrm{N}$. to lat $30^{\circ} 06.5^{\prime} \mathrm{N}$, long $110^{\circ} 24^{\prime} \mathrm{W}$. to long $110^{\circ} 28.5^{\prime} \mathrm{W}$. Outcrops of the Los Changos Quartzite, here considered to be part of the Las Víboras Group, is separated from Precambrian crystalline basement by a low-angle fault (Rodríguez-Castañeda, 1994). Where examined (lat $30^{\circ} 04.5^{\prime} \mathrm{N}$, long $\left.110^{\circ} 25.2^{\prime} \mathrm{N}\right)$, the outcrop consists of about $300 \mathrm{~m}$ of yellow-gray, very thin- to thickbedded, in part cross-stratified, medium-to very coarse-grained quartzite, containing beds of conglomerate with quartz clasts as large as $5 \mathrm{~cm}$.

CN-11, San Antonio area: centered on lat $30^{\circ} 01.5^{\prime} \mathrm{N}$., long $110^{\circ} 25.0^{\prime} \mathrm{W}$. Outcrops of Los Changos Quartzite, here considered to be part of the Las Víboras Group, separated from Precambrian crystalline rocks by a low-angle fault (Rodríguez-Castañeda, 1994). Consists of yellow-gray, fine- to medium-grained quartzite, locally containing coarseto very coarse-grained sand and granules. We correlate this unit with the El Tápiro Formation defined in the Cerro de Oro area.

CN-12, Cerro Arituaba: lat. $30^{\prime} 24.5^{\prime} \mathrm{N}$. to lat $30^{\circ} 26^{\prime} \mathrm{N}$., long $111^{\circ} 25.7^{\prime} \mathrm{W}$. to long $111^{\circ} 27.5^{\prime} \mathrm{W}$. Studies by Stewart and César Jacques-Ayala (field work, 1967) indicate a relatively thin section of Neoproterozoic and Cambrian strata composed of $352 \mathrm{~m}$ of undivided El Arpa and Caborca Formations (incomplete), $262 \mathrm{~m}$ of Clemente Formation, $6 \mathrm{~m}$ of Pitiquito(?) Quartzite, $130 \mathrm{~m}$ of undivided Papalote and Gamuza Formations, $40 \mathrm{~m}$ of the Tecolote Quartzite, $354 \mathrm{~m}$ of Cerro Prieto Formation, $40 \mathrm{~m}$ of Proveedora Quartzite, and $59 \mathrm{~m}$ of Buelna Formation.

CN-13, Cerro El Picacho area: lat. $30^{\circ} 17^{\prime} \mathrm{N}$., long $111^{\circ} 18^{\prime} \mathrm{W}$. Cerro El Picacho is composed of Neoproterozoic? dolomite and minor quartzite, here correlated with the stratigraphic section near Caborca. The strata are adjacent to, and perhaps in unconformable contact with Precambrian gneiss; Skolithos-bearing quartzite, apparently the Proveedora Quartzite, is present about $2 \mathrm{~km}$ north of Cerro El Picacho.

H-1, Near Pozo Nuevo in northern part of Sierra López: lat $29^{\circ} 25^{\prime} \mathrm{N}$. to lat $29^{\circ} 30^{\prime} \mathrm{N}$., long $111^{\circ} 16^{\prime} \mathrm{W}$. to lat $111^{\circ} 19^{\prime} \mathrm{W}$., in 1:50,000-scale quadrangle H12C39. Stratigraphic succession (Stewart and others, 1990) in two geographically separate areas. One area contains shale, silty limestone, and limestone with Early Cambrian trilobites structurally overlain by the Proveedora Quartzite. The trilobites are taxa that in California and Nevada overlie the Proveedora Quartzite (Zabriskie Quartzite in California and Nevada, suggesting that the stratigraphic succession is overturned. The second area contains about 2,700 $\mathrm{m}$ of Cambrian and Ordovician strata. The Cambrian strata consist of about 1,000 m of carbonate rock locally containing Middle Cambrian trilobites. Ordovician strata (Repetski and others, 1985; Stewart and others, 1990; Poole and others, 1995a) consist of carbonate rock and minor amounts 
of siltstone and quartzite. They are about 1,700 m thick and contain Early, Middle, and Upper Ordovician trilobites and conodonts (Stewart and others, 1990; Poole and others 1995a). The lowermost part of the unit mapped as Ordovician by Stewart and others, 1990) contains Cambrian conodonts (John Repetski, 2000,written comm.). Other references: Avila-Angulo (1987) and Amaya-Martínez and Calmus (1985).

H-2, Rancho Placeritos: centered on lat. and long: $29^{\circ} 20.6^{\prime}$ N., $111^{\circ} 16.9^{\prime} \mathrm{W}$. Locality is $1.5-2 \mathrm{~km}$ north and northeast of Rancho Placeritos, in southernmost Sierra López, about $40 \mathrm{~km}$ northwest of Hermosillo, Sonora, in El Batamote (H12C349) 1:50,000-scale quadrangle. The Rancho Placeritos area was originally described by Avila-Angulo (1987). Poole and others (1997, 1998; $2000 \mathrm{a}, \mathrm{b})$ describe the area in detail and have recognized Upper Ordovician, Silurian, Devonian, and Mississippian shelf rocks overlain unconformably by Lower Jurassic strata. The section of Paleozoic rocks is one of the better exposures of these rocks in west-central Sonora.

H-3, Sierra la Flojera: lat. and long.: At or near lat $29^{\circ} 00^{\prime} \mathrm{N}$., long $110^{\circ} 53^{\prime} \mathrm{W}$. Lower Permian shallow-water shelfal limestone and Lower Permian deep-water turbiditic siltstone, silty limestone, detrital limestone, and conglomerate (Stewart and others, 1990). The two dissimilar sequences are separated by a covered area. Based on relations in Sierra Santa Teresa (Stewart and others, 1997), $8 \mathrm{~km}$ to the east, the deep-water sequence may be in depositional contact above the shallow-water sequence and represent a deep-water basin or trough developed within the shallowwater shelf. Permian fusulinids occur in both sequences. A small outcrop of Upper Triassic rocks is present in the northern part of the area (Roldán-Quintana and González-León, 1985; Stewart and others, 1990; Lucas and and González-León, 1994).

H-4, Loma El Chihuarruita (3 km east of San José de Gracia): centered on lat $29^{\circ} 16.9^{\prime} \mathrm{N}$., long $110^{\circ} 35.1^{\prime} \mathrm{W}$. in Ures in 1:50,000-scale quadrangle H12D32. Lower and Middle Cambrian succession containing strata possibly correlative with the Puerto Blanco Formation is overlain by the Proveedora Quartzite, Buelna Formation, Cerro Prieto Formation, Arrojos Formation, and Tren Formation (Stewart and others, 2002). The locality and stratigraphy was first described by MaytorenaSilva and Esparza-Yañez (1990) and Morales-Montaño and Cota-Reyna (1990).

H-5, Cerro La Caridad: Approximately lat $29^{\circ} 12.6^{\prime} \mathrm{N}$., long $111^{\circ} 00.2^{\prime} \mathrm{W}$., in $1 ; 50,000$ scale quadrangle H12C49, $15 \mathrm{~km}$ northwest of Hermosillo. Highly deformed and metamorphosed succession of Cambrian strata (presumably the Proveedora Quartzite, Buelna Formation, Cerro Prieto Formation, and Arrojos Formation) (MaytorenaSilva and Esparza-Yañez, 1990) are reported by Morales-Montaño (1990) to be thrust over Jurassic rocks. The trilobite Elrathina (identified by A.R. Palmer, 1989, written commun.) is reported at this locality and is a characteristic trilobite of the early half of the Middle Cambrian.

H-6, Cerro El Cártamo and Cerro Las Sabanillas: $30 \mathrm{~km}$ northeast of Hermosillo, on gravel road to microwave tower: Near lat $29^{\circ} 17.5^{\prime} \mathrm{N}$., long $110^{\circ} 44.5^{\prime} \mathrm{W}$. In 1:50,000-scale quadrangle H12D31. Proveedora Quartzite with Scolithos reported by Mariano Morales-Montaño (1990, oral commun.) on Cerro El Cártamo directly east of the gravel road. According to Morales-Montaño, a dolomite is exposed in the northern part of this hill. Proveedora Quartzite also forms Cerro Las Sabanillas, one $\mathrm{km}$ west of Cerro El Cártamo and on the west side of the road, according to MoralesMontaño. 
H-8, Cerro Sahuaral area, $40 \mathrm{~km}$ northeast of Hermosillo: lat $29^{\circ} 20.75^{\prime} \mathrm{N}$., long $110^{\circ} 37.54^{\prime} \mathrm{W}$., in 1:50,000-scale quadrangle H12D32. Outcrops of Proveedora Quartzite and Arrojos Formation. Buelna and Cerro Prieto Formations not identified, but could be present. Two fossil collections were made in the area. The first collection, JS-90-9, 700 m southwest of Cerro Sahuaral, was made by M. MoralesMontaño, J. Cota-Reyna, and Stewart in March, 1990, and the fossils identified by A.R. Palmer (1990, written commun.) as Peronopsis sp. Bathyuriscus sp., Oryctocephalus sp., undet. ptychoparioid, undet. dorypygid, and possible Kootenia.. The presence of Oryctocephalus indicates an age somewhere in the early part of the Middle Cambrian. The second collection, JS-90-13, $800 \mathrm{~m}$ southwest of Cerro Sahuaral, was collection made by J. Cota-Reyna, and the fossils identified by A.R. Palmer (1990, written commun.) as Peronopsis sp., Pagetia?, indet. ptychoparioid, and indet. inarticulate brachiopods. This collection is Middle Cambrian, probably the lower half owing to the presence of Pagetia?

H-9, Cerro El Sotol area: lat $29^{\circ} 24^{\prime}$ N. to lat $29^{\circ} 28^{\prime} \mathrm{N}$, long $110^{\circ} 31^{\prime} \mathrm{N}$. to long $110^{\circ} 37^{\prime} \mathrm{W}$. Large outcrop area of Neoproterozoic strata (El Aguila Group) unconformably overlain by Lower and Middle Cambrian strata (Stewart and others (2002). The El Aguila Group consists of more than $1000 \mathrm{~m}$ of mainly dolomite, quartizte, and metasiltstone. The unconformably overlying Cambrian strata consist of the Proveedora Quartzite, 24 m thick; Buelna Formation, 120 m thick; Cerro Prieto Formation, $16 \mathrm{~m}$ thick; Arrojos Formation, $315 \mathrm{~m}$ thick; and Tren Formation, $131 \mathrm{~m}$ thick in an incomplete section. The Buelna and Arrojos Formations contain Early and Middle Cambrian trilobites (Stewart and others, 2002). U-Pb ages on detrital zircons were determined from a sample collected from the El Aguila Group at this locality (Gross and others, 2000; Stewart and others, 2001).

H-11, Rancho Sobechi area: lat $29^{\circ} 9.8^{\prime} N$., long $110^{\circ} 02.8^{\prime} \mathrm{W}$. in $1 ; 50,000$-scale quadrangle H12D43. Trilobites at this locality were originally discovered by Arturo Navarro, and recollected by Stewart and Poole (3/9/95). The trilobites (collection 27F14-12J) were identified by A.R. Palmer and R. Robison (1995, written commun.) as Tonkinella valida Tchernysheva, Peronopsis sp., Syspacephalus sp., Tomagnostus? sp., and Peronopsus depressa. Unit also contains orbiculoids and possible sponge spicules. A second collection, at lat. $29^{\circ} 09.4^{\prime} \mathrm{N}$. and long. $110^{\circ} 02.8^{\prime} \mathrm{W}$. was made by Ricardo Vega Granillo and contains essentially the same fauna as 27-F14-12J, but the trilobites are more sparse and more poorly preserved (A.R. Palmer, 1995, writtern commun). The trilobites at the first locality are in an estimated 150-m-thick unit of greenish- to olive-gray shaly siltstone and mudstone with thin interbeds of silty limestone and limestone. This unit is overlain by an estimated 250-m-thick unit of very thin-bedded limestone with sparse chert and siltstone, which in turn is overlain by perhaps $100 \mathrm{~m}$ of medium- to thick-bedded dolomite. The lower two units may be equivalent to the Arrojos Formation and the upper unit to the Tren Formation. The trilobites indicate a position high in the Ehmaniella zone (medial Middle Cambrian). The presence of agnostids and Tonkinella both indicate an open shelf environment (A. R. Palmer, 1995, written commun.).

Two collections of limestone made by Poole (95FP-70F and -71F) in Canyón de Sobechi, 250 to $400 \mathrm{~m}$ east of the abandoned Rancho Sobechi yielded late Osagean to late Meramecian conodonts (late Early to early Late Mississippian), according to A.G. Harris. Limestone unconformably(?) overlain by red siltstone and conglomerate, probably of Mesozoic age. 
H-12, Sierra López, near La Verde mine. La Verde mine is at lat. $29^{\circ} 23.7^{\prime}$, long. $111^{\circ} 17.5^{\prime}$. Menicucci and others (1982) state "The outcrops of Sierrita de López around the La Verde mine consists, beginning with the lowermost, of alternating limestone and shale. Neither the bottom nor the top of this sequence is known. Locally, these rocks are contact-metamorphosed (skarns), which indicates the existance of an underlying intrusive body. On the official geological map of Mexico, the entire sequence is represented as belonging to the Barranca Formation, and is indicated to be of Triassic age. However, the fossils we found in its lower part: crinoid stems, Calceolispongia multiformis Teichert and Fenestellides are consistent with a Lower Permian age of this sequence." Stewart and Poole have not visited this locality, and have not confirmed the Permian age.

H-13, Cerro de Oro area: lat $29^{\circ} 32^{\prime} \mathrm{N}$. to lat $29^{\circ} 40^{\prime \prime} \mathrm{N}$., long $110^{\circ} 32^{\prime} \mathrm{W}$. to long $110^{\circ} 38^{\prime} \mathrm{W}$. Major outcrop area of Neoproterozoic strata subdivided into El Tápiro, El Alamo, and Año Nuevo Formations of the Las Víboras Group (Stewart and others, 2002). These formations total at least $2,000 \mathrm{~m}$ and consist mostly of quartzite in the El Tápiro Formation, of reddish-brown arkosic sandstone and minor siltstone in the El Alamo Formation, and of quartzite, stromatolitic dolomite, and siltstone in the Año Nuevo Formation. U-Pb ages on detrital zircons were determined from a sample of the El Alamo Formation at this locality (Gross and others, 2000; Stewart and others, 2001).

H-14, Rancho las Norias-Rancho El Albañil: Center on lat. $29^{\circ} 59^{\prime}$ N., long. $110^{\circ}$ $38^{\prime} \mathrm{W}$. in 1;50,000-scale quadrangle H12D42. Paleozoic rocks in area were mapped by Vega-Granillo and Araux-Sánchez (1987,1988), Radelli and others (1987), and Peiffer-Rangin, (1988). Poole began stratigraphic studies of Paleozoic rocks in this area in 1981. Area contains carbonate shelf rocks of Early and Middle Ordovician age unconformably overlain by Devonian and Lower Mississippian carbonate rocks (Poole and others, 1995a; Page and others, 2000). New mapping and stratigraphic studies by W.R. Page and others (unpub. data, 2001) have reinterpreted the stratigraphy and structure.

Puerto el Oregano area, $3 \mathrm{~km}$ east of Las Norias, at lat $29^{\circ} 03.7^{\prime} \mathrm{N}$. , long $110^{\circ} 35.9^{\prime} \mathrm{W}$. contains Mississippian limestone (Peiffer-Rangin, 1988).

H-17, North of Cerro El Molinito, lat. $29^{\circ} 14.2^{\prime}$ N., long. $110^{\circ} 44^{\prime} \mathrm{W}$. At intersection of main Hermosillo-Ures highway and road to microwave facility. In 1:50,000 scale quadrangle H12D41. Rodríguez-Castañeda (1981) indicates that limestone with nodules and lenses of chert contains corals. These are reported to be Vesiculophylum sp., Pleurosiphonella cf. P. virginica (Butts) of Mississippian age (W.J. Sando, 1982, written commun.). Also abundant crinoid fragments.

H-18, Sierra Los Leyva, lat $29^{\circ} 04.5^{\prime}$ N., long $110^{\circ} 42.5^{\prime}$ W. In 1:50,000-scale quadrangle H12D41. Rodíquez-Castañeda (1981) indicates that the corals Caninia? sp. Petaluxis of the group P. flexuosus (Trautschold) and Michelinia sp. occur in limestone beds. Also present are fragments of crinoids and pelecypods. W.J. Sando (written commun.1982) reports the presence of Vesiculophyllum sp.,

Pleurosiphonella $\mathrm{cf}$., $P$. virginica (Butts) of probable Late Mississippian age, and Petalaxis of the group P. flexudous (Trautchold) of Middle Carboniferous, or more likely, Permian age. Poole and J. Roldán-Quintana collected corals from a pelmatozoan- and coral-bearing limestone that indicate an age of Late Mississippian to Early Permian. Conodonts derived from limestone (samples 83FP-21F and $-22 \mathrm{~F}$, lat. $29^{\circ} 05.3^{\prime} \mathrm{N}$., long $110^{\circ} 43.3^{\prime} \mathrm{W}$.) indicate Osagean (late Early Mississippian) and 
latest Meramecian-Chesterian (Late Mississippian) ages. Stewart recognized a probable Devonian quartz arenite underlying the Mississippian carbonate rocks.

H-20, southwest flank of Sierra Mazatán, north of Rancho Las Milpas, centered on lat. $29^{\circ} 03^{\prime} \mathrm{N}$., long. $110^{\circ} 15^{\prime} \mathrm{W}$. Limestone collected by R. Vega-Granillo (VegaGranillo, 1996) contains conodonts of the middle Kinderhookian (Early Mississippian), Siphonodella sandbergi Zone or younger (C. A. Sandberg, 1995, oral commun.). An Early Mississippian age for limestone at this locality is also indicated by Peiffer-Rangin (1988).

H-22, Rancho Curiel: lat $29^{\circ} 54^{\prime} \mathrm{N}$. to lat $29^{\circ} 54.5^{\prime} \mathrm{N}$., long $111^{\circ} 37.7^{\prime} \mathrm{W}$. to long. $111^{\circ} 38.5^{\prime} \mathrm{W}$.,in 1:50,000-scale quadrangle H12C18. The Neoproterozoic rocks in the Rancho Curiel area were originally mapped and described by Pérez-Soto (1991) and Vega-Granillo and others $(1991,1993)$. A more detailed study by Stewart and others (2002) divided the section into 4 units, which are, in ascending order: unit 1, quarzite and conglomerate, unit 2, dolomite and minor quartzite, unit 3, quartzite and conglomerate, and unit 4 dolomite and quartzite and minor silty limestone. Unit 3 and the lowermost part of unit 4 are correlated with part of the Clemente Formation of the Caborca area (Stewart and others, 2002).

Detrital zircons from Neoproterozoic quartzite in the Rancho Curiel area are described by Stewart and others (2001).

H-23, Rancho El Pocito (also Rancho La Pirinola): lat $29^{\circ} 57.9^{\prime}$ N. to lat $29^{\circ} 57.5^{\prime} \mathrm{N}$, long $111^{\circ} 35.6^{\prime} \mathrm{W}$. to $36^{\circ} 00^{\prime} \mathrm{W}$. In Feliz Gomez 1:50,000-scale quadrangle. Neoproterozoic dolomite and quartzite in complex structural setting (PérezSoto,1991; Vega-Granillo and others, 1991). Strata shown as resting nonconformably on crystalline basement rocks. Strata considered to correlate with the El Arpa and Caborca Formations of the Caborca area by Vega-Granillo and others (1991).

H-24, La Monarca: lat $29^{\circ} 54.5^{\prime} \mathrm{N}$. to $29^{\circ} 56^{\prime} \mathrm{N}$, long $111^{\circ} 31.0^{\prime} \mathrm{W}$ to long $111^{\circ} 33.0^{\prime} \mathrm{W}$, in Feliz Gomez 1:50,000-scale quadrangle. Well exposed and little faulted succession of Neoproterozoic dolomite and quartzite (Pérez-Soto, 1991; VegaGranillo and others, 1991; 1993). We were unable to obtain premission to visit this locality, but from low level aerial observation, the section appears to be a key stratigraphic locality that contains two major resistant quartzitic units in a dominantly dolomite succession.

H-25, Bellavista (Cerro El Mohino): lat 2953.5.'N.to lat $29^{\circ} 55.0^{\prime} \mathrm{N}$, long $111^{\circ} 23.5^{\prime} \mathrm{W}$. to $111^{\circ} 24.9^{\prime} \mathrm{W}$. Mapped by Pérez-Soto (1991). Stratigraphic succession based on Stewart and others (2002) is a follows: (1) Precambrian granite with 0.5 to $1.4 \mathrm{~cm}$ phenocrysts of feldspar; (2) unconformably overlain by about $230 \mathrm{~m}$ of Neoproterozoic quartzite with conglomerate layers in lower part; (3) about $380 \mathrm{~m}$ of dolomite, probably correlative to El Arpa and Caborca Formations; (4) about $130 \mathrm{~m}$ of medium- to very coarse-grained quartzite containing some granules and pebbles, perhaps correlative to unit 2 of Clemente Formation, or alternately, is part of overlying Mesozoic strata; (5) about $170 \mathrm{~m}$ of Mesozoic sandstone, conglomerate and argillite containing sparse volcanic clasts and silicified wood.

H-26, Los Chirriones area (includes Cerro La Argentina): lat $29^{\circ} 54.0^{\prime} \mathrm{N}$. to lat $29^{\circ} 57.3^{\prime} \mathrm{N}$, long $111^{\circ} 08.7^{\prime} \mathrm{W}$ to $111^{\circ} 10.8^{\prime} \mathrm{W}$., in $1: 50,000$-scale quadrangle H12C19. Five small isolated outcrops of Neoproterozoic dolomite and quartzite (Chaparro-Meza, 1992). Dolomite at Cerro La Argentina (57.3'N, long $\left.111^{\circ} 08.8 \mathrm{~W}\right)$ 
contains large stromatolites that look like Conophyton because they have a well defined central zone and concentric laminae characteristic of Conophyton (S. Awramik, 1995, written commun.)

H-29, Batobabi: lat $29^{\circ} 46^{\prime} \mathrm{N}$. to $29^{\circ} 47^{\prime} \mathrm{N}$., long $110^{\circ} 48^{\prime} \mathrm{W}$. to long $110^{\circ} 51^{\prime} \mathrm{W}$. Moderately faulted succession of Neoproterozoic El Tápiro, El Alamo, and Año Nuevo Formations (Stewart and others, 2002). Small stromatolites are present in the Año Nuevo Formation. Area shown on unpublished 1:50,000-scale geologic map of the La Poza quadrangle (H12D11) by the Departamento de Geología, Universidad de Sonora.

H-30, Cerro El Guayabo: lat $29^{\circ} 50^{\prime} \mathrm{N}$. to $29^{\circ} 53^{\prime} \mathrm{N}$., long $110^{\circ} 40^{\prime} \mathrm{W}$. to $110^{\circ} 46^{\prime} \mathrm{W}$. El Tápiro Formation resting nonconformably on Proterozoic crystalline basement rocks (Stewart and others, 2002)

H-32, Cerro La Vinorama: lat $29^{\circ} 55.5^{\prime} \mathrm{N}$. to lat $29^{\circ} 55.7^{\prime} \mathrm{N}$, long $110^{\circ} 40.3^{\prime} \mathrm{W}$. to long $110^{\circ} 41.2^{\prime} \mathrm{W}$. Shown as La Palma Group on unpublished 1:50,000-scale geologic map by the Departamento de Geología (Universidad de Sonora) of the La Poza (H12D11) quadrangle. Assigned by Stewart and others (2002) to Las Víboras Group.

H-33, El Carrizal area: lat $29^{\circ} 51.0^{\prime} \mathrm{N}$. to $29^{\circ} 52.0^{\prime} \mathrm{N}$., long $110^{\circ} 39 \mathrm{~W}$. to $110^{\circ} 42^{\prime} \mathrm{W}$. Orthoquartzite and quartzo-feldspathic sandstone, some conglomerate; $667 \mathrm{~m}$ measured by Figueroa-Valenzuela and Grijalva-Haro, 1989). Assigned by Stewart and others (2002) to the Las Víboras Group. Outcrops include the La Variedad area west of El Carrizal. Some of the quartzite mapped in the La Variedad area, west of El Carrizal, by the Departamento de Geología, Universidad de Sonora, could be Mesoproterozoic in age because quartzite of this older age is known in the Cerro El Guayabo area, and previously mapped as Neoproterozoic in age.

H-34, El Batamote: lat $29^{\circ} 50.9^{\prime} \mathrm{N}$. to $29^{\circ} 51.7^{\prime} \mathrm{N}$., long $110^{\circ} 38.0^{\prime} \mathrm{W}$. to long $110^{\circ} 38.8^{\prime} \mathrm{W}$. Figueroa-Valenzuela and Grijalva-Haro (1989) measured $122 \mathrm{~m}$ of quartzite, in part feldspathic. Assigned by Stewart and others (2002) to the Las Víboras Group that is at least in part the El Alamo Formation.

H-35, El Resbaladero: lat $29^{\circ} 55.5^{\prime} \mathrm{N}$. to lat $29^{\circ} 56.5^{\prime} \mathrm{N}$., long $110^{\circ} 39^{\prime} \mathrm{W}$. to long $110^{\circ}$ 40 W. Figueroa-Valenzuela and Grijalva-Haro (1989). Neoproterozoic strata assigned by Stewart and others (2002) to the Las Víboras Group that is at least in part El Tápiro Formation.

H-36, El Carrizo: centered on lat $29^{\circ} 59^{\prime}$ N., long $110^{\circ} 31^{\prime} W$. Figueroa-Valenzuela and Grijalva-Haro (1989). Assigned by Stewart and others (2002) to the Las Víboras Group, probably the El Tápiro Formation.

H-37, El Chichiquelite: centered at lat $29^{\circ} 59.5^{\prime} \mathrm{N}$., long $110^{\circ} 29.5^{\prime} \mathrm{W}$. FigueroaValenzuela and Grijalva-Haro (1989) report that the basal $3 \mathrm{~m}$ of the stratigraphic succession is polymictic conglomerate with clasts of gneiss, granite, sandstone, and quartzite from 4 to $6 \mathrm{~cm}$ in size. The conglomerate is overlain by rose-colored, laminated and cross-stratified orthoquartzite. Figueroa-Valenzuela and Grijalva-Hara (1989) show these rocks as in depositional contact with Precambrian crystalline rocks, but Stewart and others (2002) observed an apparent low-angle fault contact between quartzite and the Precambrian crystalline basement. The quartzite and 
conglomerate are considered by Stewart and others (2002) to be El Tápiro Formation of the Las Víboras Group.

H-38, Las Granadas: centered on lat $29^{\circ} 59.5^{\prime} \mathrm{N}$., long $110^{\circ} 24^{\prime} \mathrm{W}$. Quartzo-feldspathic sandstone, quartz-sandstone, orthoquartzite, conglomeratic sandstone, and layers of conglomerate (Figueroa-Valenzuela and Grijalva-Haro (1989). Apparently part of the Las Víboras Group (Stewart and others, 2002)

H-39, Cerro El Garrote: centered at lat $29^{\circ} 54^{\prime} \mathrm{N}$, long $110^{\circ} 32.0^{\prime} \mathrm{N}$. FigueroaValenzuela and Grijalva-Haro (1989). Apparently part of the Las Víboras Group (Stewart and others, 2002)

H-40, Cerros Las Palmitas, Piedra Verde, and La Cachimba: lat $29^{\circ} 47.5^{\prime} \mathrm{N}$. to lat $29^{\circ} 48.2 \mathrm{~N}$., long $110^{\circ} 26.0^{\prime} \mathrm{W}$. to $110^{\circ} 28.0^{\prime} \mathrm{W}$. Figueroa-Valenzuela and GrijalvaHaro (1989). Apparently part of the Las Víboras Group (Stewart and others, 2002).

H-41, Cerro Las Morras: lat $29^{\circ} 42^{\prime} \mathrm{N}$. to lat $29^{\circ} 44^{\prime} \mathrm{N}$., long $110^{\circ} 25.5^{\prime} \mathrm{W}$. to long $110^{\circ} 26.0 \mathrm{~W}$. Mapped by Castro-Rodríguez and Morfín-Velarde (1988a,b). Locality contains perhaps as much as $300 \mathrm{~m}$ of yellowish-gray and grayish-red, fine- to medium-grained, laminated and cross-stratified quartzite containing local conglomerate (Stewart and others, 2002). Las Víboras Group, probably El Tápiro Formation.

H-42, La Chepa: lat $29^{\circ} 32^{\prime} \mathrm{N}$. to lat $29^{\circ} 36^{\prime} \mathrm{N}$., long $110^{\circ} 47^{\prime} \mathrm{W}$. to long $110^{\circ} 49^{\prime} \mathrm{W}$. A nearly 1,000-m-thick section of dolomite and minor amounts of quartzite (ValenzuelaRentería and Aguirre-Fimbres, 1995; Stewart and others, 2002). Probably of Neoproterozoic age. Area also contains small outcrops of the Lower Cambrian Proveedora Quartzite and of oncolith-bearing limestone of the Lower Cambrian Cerro Prieto Formation.

\section{H-44, 6 km nothest of Rancho Las Barajitas (southernmost Cerro El Carnero} area): centered on lat. $29^{\circ} 32^{\prime} \mathrm{N}$., long $111^{\circ} 24.2^{\prime} \mathrm{W} ., 1: 50,000$-scale quadrangle map H12C28. A sample of a coral-bearing carbonate unit collected by Stewart in 1994 contained conodonts of Middle, or possibly Late Devonian, age (C.A.

Sandberg, 1995, oral commun.). Poole collected three samples of limestone in 1996 that yielded late Late Devonian conodont faunas identified by A.G. Harris (1997, written commun.).

H-45, Cerro El Carnero: centered on lat $29^{\circ} 33.2^{\prime} \mathrm{N}$, long $111^{\circ} 24.4^{\prime} \mathrm{W}$., 1:50,000-scale quadrangle map H12C28. Poole, W.R. Page, and R. Amaya-Martínez measured and sampled a section of Ordovician, Silurian, and Devonian rocks (field work, 1997) about $1 \mathrm{~km}$ southwest of Cerro El Carnero. Lithofacies and conodont faunas identified by A.G. Harris (1996-1997, written commun.), confirm the Ordovician, Silurian, and Devonian age of the rocks measured. Also see Poole and others (1997; 1998).

IA-1, Punta La Ona, also called Punta Unah): Lat. $29^{\circ} 03.0^{\prime} \mathrm{N}$., Long. $112^{\circ} 9.8^{\prime} \mathrm{W}$. About $2.5 \mathrm{~km}$ south southwest of Punta La Ona, about $3 \mathrm{~km}$ north northeast of Punta Chueca 1:50,000 scale map. Mapped as "Ms" (Mesozoic(?) sedimentary rocks) by Gastil and others, (1974); apparently same locality as mentioned by Gastil and Krummenacher (1977) and Gastil and Miller (1981; 1984). Stewart examined the area in 1993 and found the rocks to consist of metachert, metasiltstone, and calcsilicate hornfels. Perhaps some rocks are quartzite, because grain size is at least medium in places, but most of rock appears to be metachert, not quartzite. Stewart considers the rocks to be deep-water Paleozoic strata. Gastil and Miller (1984) 
correlate, with uncertainty, the rocks at Punta La Ona with deep water chert-rich rocks at Puerto Calamajue on the west side of the Gulf of California. The rocks at Puerto Calmujue are at least partly Late Mississippian in age (Griffith and Hobbs, 1993).

IA-2, 4.5 km south-southeast of Pozo Coyote: lat $29^{\circ} 34.9 \mathrm{~N}$., long $112^{\circ} 22.5^{\prime} \mathrm{W}$. Mapped by Gastil and others (1974) as "Mq" (Mesozoic? quartzite). Field examination by Stewart in 1988 indicates a succession of quartzite and schist probably $300 \mathrm{~m}$ thick. Quartzite is very fine textured metamorphic rock that was originally a very fine-grained sandstone. Original sedimentary laminae and possible cross-strata visible. Possible clasts of metasiltstone in places. No carbonate, chert, or conglomerate seen. Age of strata unknown. Quartzite does not resemble that in Neoproterozoic and Cambrian of Caborca region which is mostly coarser grained. Could be Mesozoic, but if so, absence of volcanic, carbonate, and conglomerate rocks is puzzling. Alternatively, could be an unusual facies of Paleozoic strata west of the miogeoclinal margin.

IA-3, Punta Chueca area: lat $29^{\circ} 00^{\prime} 40^{\prime \prime} \mathrm{N}$., long $112^{\circ} 08^{\prime} 25^{\prime \prime} \mathrm{W} ., 2 \mathrm{~km}$ east-southeast of Punta Chueca village. Examination of locality by Poole and R. Amaya-Martínez in 1998. Intensely calcsilicated limestone-marble layers several meters thick intercalated with siliceous argillite and calcsilicate rock. No chert units were seen where traversed. However, chert (or metachert) reported at IA-1 (Punta La Ona) by Gastil and Miller (1984) and by Stewart (field examination, 1993). Relations of localities IA-1 and IA-3 are uncertain. Gastil and Miller (1984) and Stewart consider locality IA-1 to be Paleozoic eugeoclinal strata whereas Poole and Amaya-Martínez considers locality IA-3 to be most likely Mesozoic. The rocks at the two localities could be part of the same sedimentary package, which could be composed entirely of either Paleozoic eugeoclinal strata, or of Mesozoic strata. Alternately, the two localities could be composed of different age rocks, locality 1A-1 could be Paleozoic and locality $1 \mathrm{~A}-2$ could be Mesozoic.

IA-4, northwest Tiburón Island: centered on lat $29^{\circ} 15^{\prime} \mathrm{N}$., long $112^{\circ} 13 \mathrm{~W}$. Gastil and Krummenacher (1977) report chert associated with carbonate rock and a variety of clastic rocks in northwestern Tiburón Island. Gastil and Miller (1984) correlate these rocks with uncertainty with deep-water strata at Puerto Calamujue on the west side the Gulf of California. The Puerto Calamuje strata are at least partly Late Mississippian in age. We did not examine this locality.

IS-1, northern part of Turner Island: lat $28^{\circ} 43.7^{\prime} \mathrm{N}$., long $112^{\circ} 17.7^{\prime} \mathrm{W}$., 1:50,000scale quadrangle map H12-10. Northern part of island contains succession of metaargillite, chert, siliceous argillite, siltite, and minor limestone and dolostone (Poole and others, 1993a, b). The succession in the southern part of the island is similar although it contains several major carbonate units. Poorly preserved graptolites in the northern part of the island are late Middle-early Late Ordovician. Poole and others (1993) correlate the graptolite-bearing argillite and associated chert with the El Yaqui Chert in the Barita de Sonora area, $100 \mathrm{~km}$ east of Hermosillo (Poole and others, 1993a,b; 1995b).

IS-2, Cerro Tordillo and prominent hill about $1 \mathrm{~km}$ northwest of Cerro Tordillo: centered at lat 28 58'15", long 112 03'10"W. Mapped as "Mc" (Meozoic(?) carbonate-rich rocks) by Gastil and others (1974). Outcrop consists (Poole and R. Amaya-Martínez, field examination, 1998) of intensely altered and recrystallized limestone and clayey-silty limestone. Some interbedded platy limestone and 
calcisilicate units contain sparse siliceous (cherty) shale layers as much as $2 \mathrm{~m}$ thick. Abundant outrcops of coarse-grained granitoid rocks and very thin-bedded calcsilicate rock. Sequence is considered by Poole to be probably Paleozoic carbonate-shelf rocks, but is too metamorphosed to identify units without more detailed study.

M-1, Sierra Agua Verde: Centered at lat $29^{\circ} 14^{\prime}$ N., long 109 $53^{\prime} W ., 1: 50,000$ scale quadrangle map H12D44. Over 3,700 m of Neoproterozoic(?), Cambrian, Lower Ordovician, Upper Devonian, Mississippian, and Lower and Middle Pennsylvanian inner-shelf miogeoclinal strata are exposed (Stewart and others, 1984, 1988, 1999a; Poole and others, 1984, 1995a; Repetski and others, 1985). The area was first recognized by Françoise Peiffer-Rangin in the 1970's (Peiffer-Rangin, 1988). The area also has been described by Minjarez-Sosa and others (1993) and Ochoa-Granillo and Sosa-León (1993) who report Permian strarta in the area as well. Gehrels and Stewart (1998) and Stewart and others (2001) determined the ages of detrital zircons from the Proveedora Quarzite of Early Cambrian age and from a sandstone of Late Devonian age in the section at Sierra Agua Verde.

M-2, Puerto de Matape (apparently pass on road between Mátape to Novillo Reservoir in southern part of Sierra Agua Verde): lat $29^{\circ} 10.7^{\prime} N$. , long $109^{\circ} 52.4^{\prime} \mathrm{W}$. Probably near "El Puerto" on 1:50,000 scale map. Peiffer-Rangin (1988) reports $270 \mathrm{~m}$ of dominantly carbonate rock of Early Mississippian age.

M-4, Cerro Prieto: presumably Cerro Prieto shown on 1:50,000-scale quadrangle map H12D44, lat $29^{\circ} 05.7^{\prime} \mathrm{N}$., long $109^{\circ} 58.0^{\prime} \mathrm{W}$., about $2.5 \mathrm{~km}$ south of Mátape (Villa Pesquería). Recrystallized limestone containing corals and pelmatozoan detritus Peiffer-Rangin, 1988). Tentatively assigned a Mississippian age by Peiffer-Rangin (1988).

M-5, Cerro Tepupa: Cerro Tepupa is listed by Peiffer Rangin (1988) as on "southern flank" of Presa del Novillo, but is not shown on 1:50,000-scale quadrangle map H12D44 of the area. Perhaps Cerro Tepupa is unnamed cerro $3 \mathrm{~km}$ east of of the village of Tepupa. The village of Tepupa is at lat. $29^{\circ} 10.5^{\prime} \mathrm{N}^{\prime}$., long. $109^{\circ} 45.1^{\prime} \mathrm{W}$. Peiffer-Rangin (1988) describes the locality as containing a small block of Mississippian limestone with pelmatozoan detritus and brachiopods.

M-6, Cerro San Pedro (also known as Cerro Azogue): lat. $29^{\circ} 16.8^{\prime}$, long. $109^{\circ}$ 43.0', 1:50,000-scale quadrangle map H12D34. Two kilometers southeast of village of San Pedro de la Cueva on east side of El Novillo Reservoir. Peiffer-Rangin (1988) describes $290 \mathrm{~m}$ of largely limestone and minor siltstone. The limestone contains corals, brachiopds, bryozoans, sponges, and pelmatozoan detritus of Tournaisian and Viséan (Mississippian) age (Peiffer-Rangin, 1988).

M-7, Sierra Chiltepín and Cerro El Carrizo area: lat $28^{\circ} 57^{\prime}$ N. to lat $29^{\circ} 06^{\prime} \mathrm{N}$., long $109^{\circ} 15.9^{\prime} \mathrm{W}$. to long $109^{\circ} 22^{\prime} \mathrm{N}$., in 1:50,000-scale maps H12D45, H12D46, and H12D55, and H12D56. The area has been mapped and described by Flinn (1977), Himanga (1977), Almazán-Vázquez (1989), Fernández-Aquirre and AlmazánVázquez (1991), Fernández-Aguirre and others (1995), Pubellier and others (1995), and Stewart and others (2002). The stratigraphic succession, named the Cerro Las Bolas Group by Stewart and others (2002) is 2,600 m thick and divided into four formations (Mina el Mezquite, Monteso, Sierra Chiltepín, and Macho Formations) composed of shallow-water dolomite, quartzite, siltstone, limy siltstone, and sparse conglomerate. A Sturtian-age (ca $700 \mathrm{Ma}$ ) glacial diamictite and cap carbonate (Corsetti and others, 2001) is present at the faulted base of the group. U-Pb ages of 
detrital zircons were determined from samples collected from the Sahuaripa Member of the Monteso Formation and from the Sierra Chiltepín Formation at this locality (Stewart and others, 2001).

M-8, Loma La Bellotita (San Francisco mine; $3 \mathrm{~km}$ north of Mátape): Lat. $29^{\circ} 08^{\prime} \mathrm{N}$. to $29^{\circ} 09.5^{\prime} \mathrm{N}$., long $109^{\circ} 57^{\prime} \mathrm{W}$. to $109^{\circ} 59^{\prime} \mathrm{W}$., in $1: 50,000$-scale map H12D44. Metamorphosed and faulted succession, possibly $800 \mathrm{~m}$ or more, thick. What appears to be the lower part of the succession in the western part of the outcrop consists of several hundred meters of schist and quartzite overlain by 70 ? $\mathrm{m}$ of medium- to very coarse-grained quartzite, locally containing quartz clasts as large as about $1 \mathrm{~cm}$. East and presumably upsection from this quartzite is several hundred meters of marble and hornfels within which the stratigraphic succession is not well defined. The entire succession is overlain along what appears to be a low-angle fault by relatively unmetamorphosed limestone containing pelmatozoan detritus. The lower part of the succession (schist and quartzite) may be related to the Las Víboras or El Aguila Groups northeast of Hermosillo (Stewart and others, 2002), and the higher? hornfels and marble may be lower or middle Paleozoic strrata. However, these correlations are speculative.

M-9, Sierra El Carrizo, about $8 \mathrm{~km}$ east of Mátape: centered on lat $29^{\circ} 06.5^{\prime} \mathrm{N}$., long $109^{\circ} 51.7^{\prime} \mathrm{W}$. In the 1:50,000-scale map H12D44. This locality is shown on the map of Radelli and others (1987, plate 1) as part of an allochthonous sequence (eugeoclinal rocks). The rocks that apparently are what Radelli and others(1987) called allochthonous at Sierra El Carrizo are highly folded, but are mostly thin-bedded meta-limestone and limy siltstone that are considered by Stewart to be miogeoclinal, rather than eugeoclinal. They don't appear to be a chert-argillite sequence similar to that in eugeoclinal strata in Sonora. The folded thin-bedded meta-limestone and limy siltstone sequence could be Ordovician because it contains some limestone-clast conglomerate beds similar to that in Ordovician rocks at Sierra Martínez, Rancho Las Norias, and Sierra López; however, the sequence contains lesser amounts of massive limestone than those localities. Strata below the sequence could be partly Cambrian in age.

M-10, Rancho La Tinaja area: Referenced as "Cerro de la Tinaja" by Peiffer Rangin (1988) and Cerro Tinaja by Menicucci (1982). Rancho La Tinaja is at lat $29^{\circ} 00^{\prime} 15^{\prime \prime} \mathrm{N}$., long 109 $50^{\prime} 20^{\prime \prime} \mathrm{W}$., in 1:50,000-scale map H12D44. North of Llano Colorado village. Exact location uncertain, but probably east of Rancho La Tinaja in Sierra el Máviro, according to Poole. Menicucci and others (1982) lists several genera of fusulinids from this locality. Peiffer-Rangin (1988) indicates a section, about 150 to $200 \mathrm{~m}$ thick, of limestone with common fusulinids, bryozoan, brachiopods, ostracods, and pelmatozoan detritus. Radelli and others (1987, plate 1) mapped upper Paleozoic limestone overthrust by allochthonous Paleozoic eugeoclinal rocks in this area. Poole has examined this area and concurs with their interpretation.

ME-1, Ejido Serdan, alternately called El Capitan): Locality is shown on Figure 1, lat $32^{\circ} 18^{\prime} \mathrm{N}$., long $112^{\circ} 50^{\prime} \mathrm{W}$. This locality is about $50 \mathrm{~km}$ south of Yuma (USA), about $40 \mathrm{~km}$ east southeast of San Luis in Mexico, and about $6 \mathrm{~km}$ south of the USMexican border. The succession is highly metamorphosed equivalents of the Permian Supai Group, Coconino Sandstone, Kaibab Limestone, and Mesozoic strata (Leveille, 1984; Fitts,1989). These are cratonal cover strata that are elsewhere exposed at scattered localities in western Arizona and in extensive outcrops in northern Arizona. The Ejido Serdan locality is important because it lies south of the position of the hypothetical Mojave-Sonora megashear as drawn by Silver and Anderson (1974)) and 
Anderson and Schmidt (1983), yet appears to contain a continuation of strata from north of the megashear in southwestern Arizona and southern California. This relation has been used as a argument against the existance of the megashear (Hamilton, 1987). Alternately, if the megashear does exist,its trace must be south of Ejido Serdan, or the Ejido Serdan rocks have overriden the megashear in an allochthonous plate from an original position to the north of the proposed fault (see discussions and references in Stewart and others, 1990, 1999a)

NG-1, Sierra EI Tule: (same as Sierra de la Huachuca locality of Aponte-Barrera, 1974 and López-Ramos, 1982), lat $31^{\circ} 16^{\prime} 50^{\prime \prime}$ N. to lat $31^{\circ} 19^{\prime} 00^{\prime \prime} \mathrm{N}$., and long $110^{\circ} 15^{\prime} 50^{\prime \prime} \mathrm{W}$. to long $110^{\circ} 20^{\prime} 00^{\prime \prime W}$. González-León $(1982,1984,1986,1987)$ and Cevallos-Ferríz and González-León (1984) reported that Sierra El Tule contains a 1,203-m-thick section of Paleozoic rocks. Cambrian rocks consist of a lower unit of sandstone which rests on Precambrian granitic rock. These rocks are only partly exposed, perhaps about $140 \mathrm{~m}$ thick, and are correlated with the Bolsa Quartzite of Arizona. Overlying this sandstone are $170 \mathrm{~m}$ of shallow-water marine carbonate rocks containing early Late Cambrian trilobites. These strata are correlated with the Abrigo Limestone of Arizona. Ordovician and Silurian rocks are not present. Upper Devonian rocks disconformably overlie the Cambrian rocks. They are $144 \mathrm{~m}$ thick and consist of shallow-water marine carbonate rocks correlated with the Martin Formation of Arizona. Disconformably overlying the Upper Devonian rocks are $297 \mathrm{~m}$ of shallow-water carbonate strata of Mississippian (Kinderhookian-Osagean) age that is correlated with the Escabrosa Limestone in Arizona. Disconformably above the Mississippian strata are $387 \mathrm{~m}$ of shallow-water carbonate rock of Pennsylvanian age that is correlated with the Horquilla Formation of Arizona. In fault contact with Pennsylvanian rocks are 140 $\mathrm{m}$ of strata of Early Permian (Wolfcampian) age. The Permian strata consist of shallow-water marine sandstone and conglomerate (clasts as large as $5 \mathrm{~cm}$ ) in the lowermost part and carbonate rocks in the remainder of the unit. The Permian strata are correlated with the Earp Formation of southern Arizona.

NG-2, Rancho La Cueva: centered on $31^{\circ} 14^{\prime} 50^{\prime \prime}$ N., $110^{\circ} 29^{\prime} 00^{\prime \prime} \mathrm{W}$. From stratigraphic base to top, the La Cueva locality (Blodgett and others, 1998) exposes an incomplete section of the Lower Permian Colina Limestone (minimum thickness, 235m), Lower Permian Epitaph Dolomite (11 m thick), and an incomplete section of the Lower Permian Scherrer Formation (minimum thickness, $54 \mathrm{~m}$ ). Megafossils from the La Cueva locality indicate a late Wolfcampian (early Early Permian) and Leonardian (late Early Permian) age for the Colina (Blodgett and others, 1998), consistent with its age in southern Arizona (Gilluly and others, 1954; Wrucke and Armstrong, 1987). No fossils have been recovered from the Epitaph and Scherrer at the La Cueva locality, but these units are assumed to be Leonardian based on correlation with units in southern Arizona. The Colina and Epitaph are carbonate units deposited on a shallow-marine platform. The Scherrer consists of thin-bedded fine-grained sandstone, siltstone, and lime mudstone that reflect input of siliciclastic detritus onto the platform in late Leonardian time (Blakey and Knepp, 1989).

NZ-1, Sierra Los Ajos: lat $30^{\circ} 47^{\prime} 00^{\prime} N$. to lat $31^{\circ} 00^{\prime} 30^{\prime \prime}$ N., long $109^{\circ} 47^{\prime} 30^{\prime \prime} \mathrm{W}$. to long. $110^{\circ} 02^{\prime} 50^{\prime \prime W}$. Large mountain range composed mostly of Paleozoic rocks. Described by Bridges (1970), Aponte-Barrera (1974), and López-Ramos (1982). Aponte-Barrera (1974) indicates $180 \mathrm{~m}$ of Cambrian Bolsa Quartzite resting unconformably on the Precambrian Pinal Schist. The Bolsa is overlain by $175 \mathrm{~m}$ of Middle and Upper Cambrian Abrigo Formation which, in turn, is unconformably overlain by $150 \mathrm{~m}$ of the Devonian Martin Formation and $160 \mathrm{~m}$ of the Mississippian Escabrosa Limestone. 
Also in the Sierra de Los Ajos ("Mustenas Mountains" of Taliaferro, 1933), Bridges (1970) reports $131 \mathrm{~m}$ of Bolsa Quartzite, $173 \mathrm{~m}$ of Abrigo Formation, $84 \mathrm{~m}$ of Martin Formation, and an incomplete Escabrosa Limestone that is $85 \mathrm{~m}$ thick.

NZ-2, Bacoachi (Cerro La Cal): centered on lat $29^{\circ} 36.8^{\prime} \mathrm{N}$, long $109^{\circ} 57.0^{\prime} \mathrm{N}$. Probably 50 to $100 \mathrm{~m}$ of laminated, cross-stratified, and bioturbated quartzite (Bolsa Quartzite) resting unconformably on Precambrian porphyritic granite. Quartzite locally contains U-shaped trace fossils, probably Monocraterion, overlain by poorly exposed and structurally distorted thin-bedded limestone, probably the Abrigo Formation, and this, in turn, is overlain by altered carbonate rocks that may include the Devonian Martin Formation and, at the top, the Mississippian Escabrosa Limestone (R. Blodgett, oral commun., 1993). Limestone in the position of the Abrigo and Martin Formations are injected by numerous mafic (diabasic?) dikes and sills 10 to $20 \mathrm{~m}$ wide. Early Mississippian conodonts were collected by Poole and W.R. Page and identified by A.G. Harris from the Escabrosa at this locality (1997, unpubl. data). U-Pb ages on detrital zircons were determined from a sample collected from the Bolsa Quartzite at this locality (Kurtz and others, 1998; Grose and others, 2000; Stewart and others, 2001).

NZ-2A, Cañon de Santa Rosa (also called El Tigre area): lat $30^{\circ} 34^{\prime} \mathrm{N}$. to lat $30^{\circ} 37^{\prime} \mathrm{N}$., long $109^{\circ} 06^{\prime} \mathrm{W}$. to long $109^{\circ} 10^{\prime} \mathrm{W}$. Located "a few miles southeast of $\mathrm{El}$ Tigre" by Imlay (1939), and as "5 miles southeast of El Tigre" by Dunbar (1939). Locality described by Imlay (1939), Dunbar (1939), Montaño (1986), Devery (1979), and Holcomb (1979). Imlay (1939) divided the section in Cañon de Santa Rosa into 5 members. From oldest to youngest these are: Member 5, $885 \mathrm{ft}(270 \mathrm{~m})$ thick, thickto medium-bedded limestone with some chert, abundant pelmatozoan debris, bryozoans, and sparse corals and brachiopods. Brachiopods are of Mississippian (preSte. Genevieve age). Member 4, $373 \mathrm{ft}$ (114 m) thick, thin-bedded limestone and shale, three brachiopod collections indicate Mississippian Ste. Genevieve age. Member 3, 2,380 ft (726 m) thick limestone with some beds chert; Leonardian fusulinids (Dunbar, 1939) $120 \mathrm{ft}(37 \mathrm{~m})$ from top. Base of fusulinid-bearing beds about $410 \mathrm{ft}$ $(125 \mathrm{~m})$ below top. Member 2, $715 \mathrm{ft}$ (218 m) thick, thin-bedded limestone with many layers of chert: probable Leonardian fusulinids near base (Dunbar, 1939). Member 1, $1,155 \mathrm{ft},(352 \mathrm{~m})$ thick, thick-bedded limestone with chert nodules; fusulinids common, but not preserved well enough for identification. If Pennsylvanian strata are present, they must occur in lower part of unit 3.

Holcomb (1979) and Devery (1979) restudied Cañon de Santa Rosa. They recognized the same 5 members as Imlay (1939) and applied the name El Tigre Formation to the entire 5 members following the nomenclature of Alvarez (1949). They dated the rocks on the basis of conodonts. According to Holcomb (1979) and Devery (1979) (also see Poole and others, 1995a), Member 5 contains $25 \mathrm{~m}$ of Ordovician strata in its lowermost part; the base is not exposed. The upper $213 \mathrm{~m}$ of Member 5 is Mississippian (Osagean and Meramacian) limestone. Member 4 is $91 \mathrm{~m}$ of Mississippian (Meramican and Chesterian) limestone. Member 3 is $565 \mathrm{~m}$ of Pennsylvanian (Morrowan to Virgilian) limestone and Permian (late Wolfcampian) limestone and dolomite. Member 2 is $198 \mathrm{~m}$ of Permian (Leonardian) silty limestone. Unit 1 is $432 \mathrm{~m}$ of Permian (Guadalupian?) limestone and dolomite.

NZ-3, Cañon de Noche Triste (also called Pilares de Teras area): lat $30^{\circ} 36^{\prime} 30^{\prime \prime} \mathrm{N}$. to lat $30^{\circ} 42^{\prime} \mathrm{N}$., long $109^{\circ} 12^{\prime} \mathrm{W}$. to long $109^{\circ} 15^{\prime} 30^{\prime \prime} \mathrm{W}$. Latitude and longitude shown are extent of outcrops of Paleozoic rocks on INEGI map of the Nacozari quadrangle (H12-6). Described as "about 1 mile northeast of Mina Pilares de Teras" by Dunbar (1939), and "along Cañon de Noche Triste which drains westward 
from the Sierra de Teras about half a mile north of the mining village" by Imlay (1939). On regional map by Imlay (1939), Pilares de Teras is shown about $8 \mathrm{~km}$ northwest of El Tigre. Imlay (1939) reports several thousand feet of limestone along Cañon de Noche Triste that he correlates with units 1, 2, and 3 at Cañon de Santa Rosa (NZ-2). The upper two units contain many fusulinids of probable Leonardian age (Dunbar, 1939).

NZ-4, Sierra Huchita Hueca area: lat $30^{\circ} 35^{\prime}$ N. to lat $30^{\circ} 37^{\prime} 30^{\prime \prime}$ N., long $108^{\circ} 55^{\prime} \mathrm{W}$. to long $108^{\circ} 52^{\prime} \mathrm{W}$. Latitude and longitude drawn from outcrop pattern on maps of INEGI, but these outcrops are mostly on southwest side of Sierra Huchita Hueca whereas Imlay (1939) and Dunbar (1939) indicate that outcrops also cap the next highest peak in the range. Imlay (1939) reports limestone ranging from a few hundred to about 1,000 ft (305 m) thick along the southern and southwest side of Sierra Huchita Hueca. Fusulinids from the highest knob at the south end of Sierra Huchita Hueca (about $11 \mathrm{~km}$ northeast of Bavispe) may be Pennsylvanian in age, and stratigraphically higher fusulinids are Leonardian in age (Dunbar, 1939).

NZ-6, Cerros las Mesteñas (La Mesa): lat $30^{\circ} 57^{\prime} \mathrm{N}$. to lat $31^{\circ} 03^{\prime} \mathrm{N}$., long $109^{\circ} 45^{\prime} \mathrm{W}$. to long $109^{\circ} 47^{\prime} \mathrm{W}$. Mapped and described by Peiffer-Rangin (1988). Stewart and R. Amaya-Martínez (field work, 1996) observed about 70 to $80 \mathrm{~m}$ of Middle Cambrian Bolsa Quartzite resting unconformably on Precambrian schist (lat $30^{\circ} 57.5^{\prime} \mathrm{N}$.; long $109^{\circ} 45^{\prime} \mathrm{W}$.). Overlying this, Peiffer-Rangin (1988) reported $75 \mathrm{~m}$ of Middle and Upper Cambrian Abrigo Formation, $26 \mathrm{~m}$ of the Upper Devonian Martin Formation, $140 \mathrm{~m}$ of Mississippian Escabrosa Limestone, and $140 \mathrm{~m}$ of the Pennsylvanian Horquilla Formation.

PP-1, Estación Sahuaro: Locality is shown on Figure 1, lat $31^{\circ} 10^{\prime} \mathrm{N}$., long $112^{\circ} 50^{\prime} \mathrm{W}$., partly on the Estación Sahuaro 1:50,000-scale topographic map. Calmus (1993) describes metamorphosed Paleozoic sedimentary strata on "two hills straight north of Estación Sahuaro." The rocks consists of limestone, marble, dolomite, and quartzite. Corals of probable early Paleozoic age from the succession were examined by H.W. Flügel (1991, written commun., in Calmus (1993). Several areas of Proterozoic sedimentary rocks are shown in nearby areas on the CESUES (Centro de Estudios Superiores del Estado de Sonora) 1:500,000-scale Sonora geologic map (FernándezAguirre and others, 1993).

SL-1, La Colorada: centered on lat. $28^{\circ} 47.2^{\prime} \mathrm{N}$., and long. $110^{\circ} 34.5^{\prime} \mathrm{W}$., in 1:50,000scale quadrangle map H12D52. Quartzite, argillite, and chert. Bartolini and others (1995) report 5 species of graptolites of late Middle and Late Ordovician age (Caradocian and Ashgillian). Poole and Stewart (in Poole and others, 1995b) collected Middle Ordovician graptolites from argillite associated with quartzite east of Rancho La Minita.

SL-2, Various names have been used in this area and several different sublocalities are included here. Includes Zubiate locality (number 12 of Meniccuci and others, 1982), which is apparently the same as El Subiate and C. Subiate on La Calorada 1:50,000scale quadrangle map H12D52, and Cerro Valuarte locality of Menicucci and others (1982) and Peiffer-Rangin (1988) that is about $2 \mathrm{~km}$ east of Rancho La Garita. Locality also includes C. San Francisco. Locality SL-2 is centered on lat $28^{\circ}$ $56.5^{\prime} \mathrm{N}$., long $11035^{\prime} \mathrm{W}$. Area covers several square kilometers. Menicucci and others (1982, p. 4) describe the Zubiate locality (their loc. no. 12) as sandy limestone that grades into calcareous sandstone and quartzite. They indicate that Flores (1929a) was able to fine "some Permian crinoid stems" in the limestone. At Cerro Valuarte 
(not labeled on map), $2 \mathrm{~km}$ east of Rancho La Garita, Menicucci and others (1982, fig. 7) show $400 \mathrm{~m}$ of "Leonardian limestone" overlain by $500 \mathrm{~m}$ of "Upper Permian and Triassic sandstone and quartzite." The relative positions of the Zubiate and Cerro Valuarte localities are not described. We infer that the Cerro Zubiate locality is about $1 \mathrm{~km}$ north and the Cerro Valuarte locality is about $2 \mathrm{~km}$ east of Rancho La Garita. Peiffer-Rangin (1988) indicates Leonardian fossils at Cerro Valuarte. Stewart (field work, 1982) collected fusulinids about $1 \mathrm{~km}$ northwest of Cerro San Francisco (lat $28^{\circ} 57.2^{\prime} \mathrm{N}$., long $110^{\circ} 33.5^{\prime} \mathrm{W}$.). Three samples at Cerro San Francisco contain the following fusulinids: Sample 1, staffellid, Schwagerina sp., Monodiexodina sp., Tetrataxis sp; late Wolfcampian (Early Permian). Sample 2, Schwagerina spp., Parafusulina? sp., early form; latest Wolfcampian or early Leonardian (Early Permian. Sample 3, Schwagerina sp. advanced form; late Wolfcampian (Early Permian). These fusulinids were identified by R.C. Douglass (1983, written commun.) An indeterminate horn coral (W.J. Sando, 1982, written commun.) was also found at Cerro San Francisco. Allochthonous Ordovician eugeoclinal strata are shown by Radelli and others (1987, plate 1) on the southern slope of Cerro San Francisco.

SL-3A, Cerro Cobachi area (shallow-water assemblage), centered on lat. $28^{\circ}$ 50 'N., long. $110^{\circ} 10^{\prime} \mathrm{W}$., in 1:50,000 quadrangle H12D53. Area described by Noll (1981), Noll and others (1984), Ketner and Noll (1987), and Peiffer-Rangin (1988). Area contains two structurally juxtaposed assemblages (Ketner and Noll (1987), a carbonate-quartzite, shallow-water assemblage (shown here as locality SL-3A), and a siliceous, deep-water asssemblage (shown here as locality SL-3B). The shallowwater assemblage includes Ordovician, Silurian(?), Devonian, Mississippian, Pennsylvanian, and Permian strata (Ketner and Noll, 1987; Ketner; 1986; PérezRamos, 1992; Poole and others, 1995a.

SL-3B, Cerro Cobachi area (deep-water assemblage), centered on lat. $28^{\circ} 50^{\prime} \mathrm{N}$., long. $110^{\circ} 10^{\prime} \mathrm{W}$.,in 1:50,000 quadrangle H12D53. Area described by Noll (1981), Ketner (1983), Noll and others, 1984), Ketner and Noll (1987), Peiffer-Rangin (1988), Riva and Ketner (1989), and Poole and others (1995b). The deep-water (eugeoclinal) strata includes Ordovician, Silurian(?), Devonian, Mississippian, Pennsylvanian, and Permian strata (Pregger, 1981, Ketner,1983, Ketner and Noll, 1987; Riva and Ketner, 1989, Poole and others, 1995b). Unpublished studies by Poole in the Cerro Cobachi area in 1982 indicate that strata in the Cerro Cobachi area are a continuation of the well-established succession in the Barita de Sonora area (locality T-1), $20 \mathrm{~km}$ to the northeast. The individual units recognized in the Barita de Sonora area can also be recognized in the Cerro Cobachi area.

SL-4, Sierra Santa Teresa: centered on lat. $29^{\circ} 58^{\prime} \mathrm{N}$, long $110^{\circ} 47^{\prime} \mathrm{W}$. Area has been studied by Flores (1929a, b), Rodríguez-Castañeda (1981), Peiffer-Rangin (1988), Pérez-Ramos (1992), and Stewart and other (1997). Stewart and others (1997) describe over 1,600 m of largely shallow-water carbonate strata of Late Mississippian to Middle Pennsylvanian, and Early Permian age, and apparently unconformably overlying deep-water siliciclastic strata of Early or Middle Permian age (Stewart and others, 1997). U-Pb ages on detrital zircons were determined on a sample of Early or Middle Permian deep-water siliciclastic quartzite at this locality (Gehrels and Stewart, 1998).

SL-5, Cerros El Aguaje (=Torres locality): $32 \mathrm{~km}$ southeast of Hermosillo and 3-8 $\mathrm{km}$ north of Torres in southeast part of Torres 1:50,000-scale quadrangle map H12D51, centered on lat. $28^{\circ} 49.2^{\prime} \mathrm{N}$. and long. $110^{\circ} 46.0^{\prime} \mathrm{W}$. Very poorly 
preserved graptolites collected in 1991 by Stewart, M.Morales-Montaño, and J. Cota from west side of small hill, $2.15 \mathrm{~km} \mathrm{S12W}$ of C. El Aguaje and $1.4 \mathrm{~km}$ due east from railroad tracks, lat. $28^{\circ} 48.1 \mathrm{~N}$., long. $110^{\circ} 46.3 \mathrm{~W}$. Identified by Claire Carter (1991, oral commun.) as biserial graptolites that range in age from Middle Ordovician to Early Silurian. Bartolini and others (1995) describe Ordovician chert, siltstone, and quartz arenite containing shale layers at the Cerros El Aguaje locality. Graptolites of Whiterockian to Cincinnatian age are present. Also see Poole and others (1995b).

SL-6, Cerros La Herradura, about 4 km west of San José de Pimas: uncertain location at lat. $28^{\circ} 42.8^{\prime} \mathrm{N}$, long. $110^{\circ} 23^{\prime} \mathrm{W}$., in 1:50,000-scale quadrangle H12D62 Bartolini and others (1995) reports very preserved graptolites in black shale associated with quartz arenite. The graptolites indicate a Middle to Late Ordovician age.

SL-7, Sierra de Moradillas: centered about lat. $28^{\circ} 36^{\prime} \mathrm{N}$., long. $110^{\circ} 30^{\prime} \mathrm{W}$., in 1:50,000-scale quadrangle map H12D52. Bartolini and others $(1990,1995)$ reports metamorphosed Paleozoic quartzarenite, shale, dolomite, and limestone (Abadie, 1981). Apparently the same locality described by Vassallo (1985) who reports clayey dolomite intercalated with horizons of chert. Vassallo mentions possible Ordovician graptolites at this locality.

T-1, Barita de Sonora: several square km of outcrop included under this heading, centered about lat. $28^{\circ} 55^{\prime} \mathrm{N}$., long. $109^{\circ} 58^{\prime} \mathrm{W}$. Sierra Martínez which is near Barita de Sonora is under separate heading (T-2). In 1:50,000-scale quadrangle map H12D54. The Barita de Sonora area contains widespread outcrops of preorogenic ocean-basin Ordovician, Upper Devonian, and Lower Mississippian strata, and synorogenic Upper Mississippian, Pennsylvanian, and Lower Permian strata (Poole and others, 1988; Poole and Amaya-Martínez, 2000; Poole and others, 1983, 1988, 1990, 1991, 1995b; Poole and Madrid, 1988a); Poole and Dutro (1988); Madrid and others (1988; 1990); Murchey (1990), Stewart and others, 1990. The presence of Ordovician graptolite-bearing strata in the Barita de Sonora area was first recognized by Peiffer-Rangin and others (1979) and Peiffer-Rangin and others (1980). Poole and others (in progress) are preparing a detailed geologic map of the Barita de Sonora area.

T-2, Sierra Martínez: centered at lat $28^{\circ} 57.2^{\prime} \mathrm{N}$., long $109^{\circ} 53.8^{\prime} \mathrm{W}$. In 1;50,000-scale quadrangle map H12D54). Menicucci and others (1982) orginally described the Sierra Martínez strata as all Permian. Later work by Poole, R. J. Ross, Jr., and J.E. Repetski (in Poole and others, 1995a) indicates that the carbonate rock in the lower part of the succession is Ordovician in age (based on age diagnostic trilobites, conodonts, and the gastropod Maclurites). The overlying quartzite is Middle Ordovician and the limestones above the quartzite are Devonian and Mississippian in age based on invertebrate and conodont faunas. A major unconformity separates the Ordovician quartzite from the Devonian and Mississippian limestone (Poole and others, 1995a). A major high-angle fault separates Mississippian and Permian limestones in a stratigraphic section measured by Poole and W.R. Page (unpubl. data, 1996-1997). Fusulinids were used to date the Permian limestone.

T-3, Sierra La Ciénega: centered on about lat $28^{\circ} 50.4^{\prime} \mathrm{N}$., long $109^{\circ} 50.5^{\prime} \mathrm{W}$., in 1:50,000-scale quadrangle map H12D54. Poole examined metamorphosed Ordovician ocean-basin rocks in Sierra La Ciénega with Manuel de Moises GonzálezCarlos in 1995. The metamorphosed rocks consist of intercalated very thin beds of dark-gray laminated micaceous siltite and argillite, thin beds of gray quartzite, and 
subordinate thin beds of medium-gray limestone. On the basis of lithology, Poole correlates these strata with Ordovician ocean-basin strata in Sierra El Aliso $25 \mathrm{~km}$ to the southeast (locality T-12).

T-4, Mina México area. Includes Sierra los Pinitos described by Peiffer-Rangin (1988), northern Sierra El Encinals described by Schmidt (1978), and Cerro La Zacatera area described by Hewett (1978). See also Radelli and others (1987). Area covers 7 by $10 \mathrm{~km}$ area centered on about lat $28^{\circ} 51^{\prime} \mathrm{N}$., long $109^{\circ} 24^{\prime} \mathrm{W}$.. Area contains two major successions. A lower succession about $1,000 \mathrm{~m}$ thick (called the El Tigre Formation by Schmidt, 1978, and Hewett , 1978) consists of limestone and minor dolomite and sandstone, and an upper succession, called the Mina México Formation by Schmidt (1978) and Hewett (1978). The Mina México Formation is estimated to be $1,000 \mathrm{~m}$ or more thick, and consists of yellow-brown to light-gray turbiditic siltstone and very fine-grained sandstone in graded beds from 1 to $150 \mathrm{~cm}$ thick. The strata contain Bouma sequences B,C,and E. A few calcareous siltstone layers are present. Nereites trace fossils (probably Lophoctenium) are abundant.

The lower succession contains abundant fusulinids, pelmatozoan detritus, brachiopods, gastropods, bryozoans, and ostracods. Fusulinids were mostly identified to the genus level and in the age range of early Leonardian to late Wolfcampian (R.C. Douglass and F. Peiffer-Rangin in Schmidt, 1978). Douglass identified one fusulinid as "approximately Leonardian" in age. A collection containing Parafusulina sp. Early Permian, Leonardian) identified by C.H. Stevens and reported by Vega-Granillo and Araux-Sánchez (1985) is poorly located. The formation that contains this fusulinid is reported to be below the Mina México Formation and possibly is in the same area described by Schmidt (1978) and Hewett (1978). It is reported to be southeast of the village of El Novillo.

The upper succession (Mina México Formation) yielded conodonts from two calcareous siltstone layers. The collections were made by K.B. Ketner and Stewart in 1984, and the conodonts identified by B.R. Wardlaw and R.G. Stamm in 1984.

Sample 29434 PC $(12,130)$, lat $28^{\circ} 50.34^{\prime}$ N., long $109^{\circ} 23.00 \mathrm{~W}$., contains the following conodonts:

Idiognathodus sp.

Neogondolella

Age: Pennsylvanian or Early Permian

Sample 29435-PC(12134), lat $28^{\circ} 50.39^{\prime} \mathrm{N}$., long $109^{\circ} \mathrm{W}$., contains the following conodonts:

Idiognathodus sp.

Idiognathoides sinuatus Harris and Hollingsworth

Neogondolella clarki (Koike)

Neostreptognathoides? sp.

Sweetognathus whitei (Rhodes)

Age: The fauna appears to be latest Wolfcampian with reworked late Morrowan elements.

The stratigraphic and structural relations of the two successions (El Tigre below and Mina México above) is particularly important. Schmidt (1978) and Hewett (1978) considered the contact between these two successions to be conformable and cited the consistent position in the area of the contact above a layer $1 \mathrm{~m}$ below the top of the El Tigre Formation that contains pelmatozoan detritus and black calcite nodules. Stewart and others (1990) and Stewart (2002) also considered the contact conformable and relate the stratigraphy to a similar change from shallow-water shelf deposits to deep- 
water turbiditic that occurs in Sierra Santa Teresa (locality H-43) described by Stewart and others (1997). A critical aspect of interpreting the contact as conformable is the apparent younger ages of fossils in the El Tigre Formation below the contact than in strata in the Mina México Formation above the contact. Such a relationship is suggestive of a fault contact rather than a conformable contact. However, sample 29435-PC (12134) in the Mina México Formation contains a mixed conodont fauna with Early Permian (latest Wolfcampian) conodonts and reworked Early

Pennsylvanian (late Morrowan) conodonts. Sample 29434 PC $(12,130)$ could also contain reworked conodonts. If the Mina México Formation is latest Wolfcampian, the only apparent overlap in age with the El Tigre Formation is the "approximately Leonardian" fusulinid described by R.C. Douglass and the poorly located sample of Leonard age containing Parafusulina sp. reported by Vega-Granillo and ArauxSánchez (1985). If all of conodonts in the Mina México Formation are reworked, then the maximum age of the Mina México may be latest Wolfcampian.

Radilli and others (1987, plate 1) have proposed an interpretation that, with available information, is just as likely as that outlined above. They consider the contact between the El Tigre and the Mina México to be a regional thrust along which the Mina México Formation is thrust over the El Tigre Formation and other shallowwater Paleozoic strata. Such an explanation is compatible with the possible overlap in ages of the El Tigre and Mina México Formation described above. Poole considers the Mina México Formation to be part of the widespread Sonora allochthon.

T-6, Cerro El Mogallón: lat $28^{\circ} 54^{\prime} \mathrm{N}$. to lat $28^{\circ} 55.3^{\prime} \mathrm{N}$., long $109^{\circ} 15^{\prime} \mathrm{W}$. to $109^{\circ} 18^{\prime} \mathrm{W}$. Almazán-Vázquez (1989), Almazán-Vázquez and others (1986), Almazán-Vázquez and Fernández-Aguirre (1988) report the presence of $950 \mathrm{~m}$ of Middle and Upper Cambrian limestone, silty and sandy limestone, and, near the base, sandstone and shale. Above the Cambrian is Ordovician carbonate and shale reported by AlmazánVázquez,1989) to be $475 \mathrm{~m}$ thick. (see also Poole and others, 1995a) Cambrian and Ordovician strata locally contain an abundant trilobite fauna (AlmazánVázquez,1989).

T-7, Cerro Los Orcones: centered on $28^{\circ} 50.2^{\prime} \mathrm{N}$., long $109^{\circ} 07.0^{\prime} \mathrm{W}$. Stewart and others (2002) reports pale-red to grayish-red micaceous siltstone (about 130 to $170 \mathrm{~m}$ thick) overlain? by about $80 \mathrm{~m}$ of dolomite. Siltstone lithologically similar to and correlated with the Mina de Mezquite Formation in Sierra Chiltepín.

T-8, El Potrero: centered on lat $28^{\circ} 57^{\prime}$ N., long $109^{\circ} 17^{\prime} \mathrm{W}$. Mapped as Potrero Formation by Flinn (1977) and as La Sata and El Mogallón Formations by FernándezAguirre and Almazán-Vázquez (1991). Thin- to thick-bedded limestone containing Mexicella (sample 23-F17-5J, lat. $28^{\circ} 57^{\prime} \mathrm{N}$., long $109^{\circ} 16.7^{\prime} \mathrm{W}$.) of the Albertella zone, identified by A.R. Palmer (1998, written commun).

T-9, Sierra (or Cerro) Santo Domingo (same as Sierra San Lorenzo): large area centered on lat $28^{\circ} 50^{\prime} \mathrm{N}$., long $109^{\circ} 17^{\prime} \mathrm{W}$., overlaps with T-25 locality. Fossils sent by E. Almazán-Vázquez to C.H. Stevens from three localities, (1) lat $28^{\circ} 50.3^{\prime} \mathrm{N}$., long $109^{\circ} 19.0^{\prime} \mathrm{W}$.; (2)lat $28^{\circ} 48.6^{\prime} \mathrm{N} .$, long $109^{\circ} 17.5^{\prime} \mathrm{W} .$, (3) lat $28^{\circ} 47.5^{\prime} \mathrm{N} .$, long $109^{\circ} 17.1^{\prime} \mathrm{N}$. These collections contain Acanthophyllum? sp. (probably Devonian); Pseudozaphentoides? sp. (probably Mississippian); Hustedia sp. and Composita sp. (probably Pennsylvanian); Sychnoelama sp. (Mississippian); Staffella sp., Eoparafusulina linearis?, Schwagerina diversiformis? (Early Permian, late Wolfcampian); Triticites sp., Schwagerina sp., Tetrataxis sp., Tubiphytes sp., and Punctospirifer sp. (Early Permian, probably early Wolfcampian); 
Eoparafusulina sp. (Early Permian, Wolfcampian). Additional fossils from Sierra Santo Domingo sent to C.H. Stevens by Ismael Minjarez-Sosa contain Schwagerina crassitectonia, Fistulipora sp., Rhombopora? sp., and some fossils that may be Devonian.

T-10, Cerro Peñasco Blanco: lat. $28^{\circ} 55^{\prime} \mathrm{N}$., long. $109^{\circ} 7.5^{\prime} \mathrm{W}$. Limestone described by Palafox and others (1984) and Palafox and Martínez (1985) contain a Middle Mississippian fauna of Amplexizaprhentis clinatus (Greene) and Brachytyrina sp. Although not credited by Almazán-Vázquez and Fernández-Aguirre (1987), they report the results of two Early Mississippian conodont collections obtained by Poole and R.J. Madrid in 1985 and studied by A.G. Harris. The Poole and Madrid sample locality is about $5.5 \mathrm{~km}$ southeast of Arivechi, Sonora, at lat $28^{\circ} 54.3^{\prime} \mathrm{N}$., long $109^{\circ} 07.8^{\prime} \mathrm{W}$.

T-12, Sierra El Aliso: large range centered on lat. $28^{\circ} 40^{\prime} \mathrm{N}$, long. $109^{\circ} 40^{\prime} \mathrm{W}$. Widespread outcrops of eugeoclinal (deep-water) strata of Ordovician, Devonian, Mississippian to Pennsylvanian(?), and Permian ages (Soto-Contreras and NavarroMartínez, 1987; Bartolini, 1988; Bartolini and others 1989; 1991).

\section{T-16, El Real Viejo (also called Arroyo el Real Viejo or Cañon de Real Viejo):} described as east of El Real Viejo, about lat $28^{\circ} 52.5^{\prime} \mathrm{N}$. and long $109^{\circ} 18.2^{\prime} \mathrm{W}$. Described by Minjarez and others (1985) as $300 \mathrm{~m}$ of limestone. Fossils submitted to C.H. Stevens by E. Almazán-Vázquez consist of Heterophaulactis? sp. (possibly Devonian), Acrospirifer gaspensis? (probably Late Devonian), Cyrtospirifer sp. (Late Devonian-Early Mississippian), Thamnopora? or Hererocoenites? (Devonian to Permian), Syringopora sp. (probably Mississippian), Lithostrotion sp. (Mississippian, probably Early Mississippian), and a coral similar to Tachylasma (Permian?).

T-18, Sierra El Encinal: lat $28^{\circ} 40.9^{\prime}$ N. to $28^{\circ} 42.3^{\prime}$ N., long $109^{\circ} 21.9^{\prime} W$. to $109^{\circ} 36.2^{\prime} \mathrm{W}$. In 1:50,000-scale quadrangle map H12D65. Large area containing outcrops of Ordovician, and probably other ages, of eugeoclinal strata. Common graptolites. Described by Barrera-Moreno and Domínquez-Perla (1987), Poole and others (1995a), and Bartolini and others (1995).

T-25, Ebenezer mine, $30 \mathrm{~km}$ southwest of Arivechi: near Cerro el de Pie, lat $28^{\circ} 51^{\prime} 10^{\prime \prime N}$., long 109¹8'16"W. Pérez Ramos (1992) reports 170 m of reddishbrown sandy limestone, interbedded thin- to thick-bedded red sandstone and sandy siltstone, and massive limestone. Fusulinids, pelmatozoan detritus, bryozoans, corals, and mollusks are present. The fusulinids indicate an early Leonardian-late Wolfcampian age (Pérez-Ramos,1992). A Middle Pennsylvanian (Atokan) fusulinid is present in the middle of the section according to Pérez-Ramos (1992). She indicates that this fusulinid may be in a displaced block in fault contact with the Permian section, or may represent reworking of older rocks into the Permian section.

T-26, Cerro Bola Colorado locality of Bartolini and others (1990): Reported by Bartolini and others (1990) as $5 \mathrm{~km}$ east of Rebeico (H12D54 quadrangle); apparently same as Cerro La Bolla locality shown on 1:50,000-scale quadrangle map, lat $28^{\circ}$ $53.5^{\prime} \mathrm{N}$., long $109^{\circ} 42.4^{\prime} \mathrm{W}$. Bartolini and others (1990) indicate Lower Permian (Wolfcampian) limestone turbidites at this locality, based on dating by C.H. Stevens. 
T-27, locality described by Bartolini and others (1990) as along the Rebeiquito-El Novillo road: close to locality T-28 but described by Bartolini and others (1990) as separate from locality T-28. Perhaps near lat. $28^{\circ} 53^{\prime} \mathrm{N}$. and long. $109^{\circ} 41^{\prime} \mathrm{W}$. Bartolini and others (1990), indicate "Arenigian-Llanvirnian argillites, Late DevonianEarly Mississippian chert (David Jones, 1989, written commun.), Late Devonian limestone turbidites, and Pennsylvanian (?) sandstone and chert."

T-28, Cerro El Carrizo: $3.8 \mathrm{~km}$ east-northeast of village of Rebeiquito in Rebeico 1:50,000-scale quadrangle H12D54, lat $28^{\circ} 56.7 \mathrm{~N}$., long. $109^{\circ} 42.75^{\prime} \mathrm{W}$. Locality originally described by Bartolini and others (1990). Bartolini and others (1995, loc. 3 ) indicate graptolites are Mohawkian in age (late Middle Ordovician) age based on identifications by S. C. Finney (in Bartolini and others, 1995). Poole and others (1995b, loc.3) report graptolites of Whiterockian and Mohawkian age (Middle Ordovician) west of Cerro El Carrizo and northeast of Rebeiquito.

\section{REFERENCES CITED}

Abadie, III, V.H., 1981, Geology of part of the Sierra de Moradillas, Sonora, Mexico: Stanford University, Stanford, Calif., MS thesis, 87 p.

Almazán-Vázquez, E., 1989, El Cámbrico-Ordovícico de Arivechi, en la región centrooriental del Estado de Sonora: Universidad Nacional Autónoma de México, Instituto de Geología, Revista, v. 8, no. 1, p. 58-66.

Almazán-Vázquez, E., and Fernández-Aguirre-M. A., 1987, Los terrenos Paleozoicos de la region serrana de Sonora in Paleozoico de Chihuahua, Excursión Geológica No. 2, Universidad Autónoma de Chihuahua, Gaceta Geológica , v.1, no. 1, p. 97-104.

Almazán-Vázquez, E., and Fernández-Aguirre, M.A., 1988, Estratigrafía de la Hoja Arivechi (H12D56): [abs.], in Almazán-Vázquez, Emilio, and Fernández-Aguirre, M.A., eds., Segundo Simposio sobre Geología y Minería de Sonora: Hermosillo, Sonora, Universidad Nacional Autónoma de México, Instituto de Geología, Universidad de Sonora; Dirección General de Fomento Minero del Estado de Sonora y Asociación de Ingenieros de Minas, Metalurgistas y Geólogos de México: v. 2, p. 2-3.

Almazán-Vázquez, Emilio, Palmer, A. R., and Robison, R. A., 1986, Constraints on the southern margin of North America during the early Paleozoic: Geological Society of America Abstracts with Programs, v. 18, no. 6, p. 525.

Alvarez, M., Jr., 1949, Notas sobre el Paleozoico Mexicano: Asociación Mexicana Geólogos Petróleos, v. 1, no. 1, pp. 47-56

Amaya-Martínez, Ricardo, and Calmus, Thierry, 1985, Datos preliminares sobre la geología de la Sierra López y alrededores, noroeste de Hermosillo, Sonora, México: Universidad de Sonora, Boletín del Departamento de Geología, Segunda Epoca, v. 2, no. 1 and 2, p. 60-64.

Anderson, T.H., and Schmidt, V.A., 1983, The evolution of Middle America and the Gulf of Mexico-Caribbean Sea region during Mesozoic time: Geological Society of America Bulletin, v. 94, p. 941-966.

Anderson, T. H., and Silver, L. T., 1977, U-Pb isotope age of granitic plutons near Cananea, Sonora: Econ. Geology, v. 72, p. 827-836.

Anderson, T. H., and Silver, L. T., 1979, The role of the Mojave-Sonora megashear in the tectonic evolution of northern Sonora, in Anderson, T. H., and Roldán-Quintana, J. eds., Geology of northern Sonora, (Geological Society of America Annual Meeting, guidebook trip 27): Pittsburgh, Pa., University of Pittsburgh and Hermosillo, Sonora, Instituto de Geología, U.N.A.M., p. 59-68.

Angermann, Ernesto, 1904, Apuntes sobre el Paleozoico in Sonora: Instituto de Geología México, Parergones del Instituto Geológico de México, v. 1, no. 3, p. 81-90. 
Aponte-Barrera, M., 1974, Estratigrafía del Paleozoico (cámbrico-pensilvánico) del centro de Sonora : México, D. F., Instituto Politécnico Nacional, Escuela Superior de Ingeniería y Arquitectura, tesis, $67 \mathrm{p}$.

Armella, Caudia, and Cabaleri, N.G., 1990, Paleoambiente deposicional asociado a los nivales carbonáticos portadores de Girvanella sp. en el cámbrico de Sonora, México: Revista de la Asociación Geológica Argentina, v. 45, no. 1-2.

Armstrong, A. K., Mamet, B. L., and Brunner, Palmira, 1981, Mississippian stratigraphy, southern New Mexico, Arizona, and Sonora, Mexico: Geological Society of America Abstracts with Programs v. 13, no. 2, p. 42.

Avila-Angulo, R., 1987, Consideraciónes geológicas y estratigrafícas de la porción NW de Hermosillo: Hermosillo, Sonora, México, Universidad de Sonora, tesis, 78 p.

Barr, T.D., and Kirschvink, J.L., 1983, The paleoposition of North America in the early Paleozoic: New data from the Caborca sequence in Sonora, Mexico: EOS, v. 64, no. 45, p. 689

Barrera-Moreno, Edgardo, and Dominguez-Perla, J. E., 1987, Geología de la carta Tonichi (H12D65) con enfasis en el Paleozoico porción central del Estado de Sonora: Hermosillo, Sonora, México, Universidad de Sonora, tesis, 93 p.

Bartolini, Claudio, 1988, Regional structure and stratigraphy of the Sierra El Aliso, central Sonora, Mexico: Tucson, University of Ariz., MS thesis, 189 p.

Bartolini, Claudio, Stewart, J.H., Carter, Claire, Murchey, B.L., and Repetski, J.E., 1989, Stratigraphy of Paleozoic eugeoclinal strata in Sierra El Aliso, central Sonora, Mexico: Hermosillo, Sonora, Mexico, Departamento de Geología, Universidad de Sonora, Boletín Segunda Epoca, v. 6, no. 1 and 2, p. 11-21.

Bartolini, Claudio, Morales, Mariano, Spinosa, Claude, and Finney, Stanley, 1990, Paleozoic off-shelf successions unconformably overlain by Triassic strata in central Sonora, Mexico: Evidence for a Permo-Triassic tectontic event?: Geological Society of America Abstracts with Programs, v. 22, no. 7., p. A114.

Bartolini, Claudio, Stewart, J.H., Carter, Claire, Murchey, B.L., and Repetski, J.E., 1991, Stratigraphy of Paleozoic eugeoclinal strata in Sierra El Aliso, central Sonora, Mexico (correction of incomplete publishing of article of 1989): Hermosillo, Sonora, Mexico, Departamento de Geología, Universidad de Sonora, Segunda Epoca, v. 8, no. 2 and 2, p. 73-78.

Bartolini, Claudio, Morales-Montaño, M., Barrera-Moreno, E., Domínguez-Perla, J.E., Navarro-Martínez, L.A., Luis, Soto-Contreas, L.A., Finney, S.C., and Carter, Claire, 1995, Geologic reconnaissance of Ordovician deep-marine sequences in central Sonora, Mexico, in Cooper, J.D., Droser, M.L., and Finney, S.C., eds., Ordovician Odyssey: Short Papers for the Seventh International Symposium on the Ordovician System: Fullerton, Calif., Pacific Section Society for Sedimentary Geology (SEPM), book no. 77, p. 285-289.

Blakely, R.C., and Knepp, R., 1989, Pennsylvanian and Permian geology of Arizona, in Jenney, J.P., and Reynolds, S.J., (eds.), Geologic evolution of Arizona: Tucson, Ariz., Arizona Geological Society Digest 17, p. 313-347.

Blodgett, R.B., Moore, T.E., and Gray, Floyd, 1998, Stratigraphy and paleontology of Lower Permian rocks near Rancho La Cueva, Santa Cruz sheet, northern Sonora, Mexico: Geological Society of America Abstracts with Programs, v. 30, no. 5, p. 6.

Bridges, L.W., 1970, Paleozoic history of the southern Chihuahua tectonic belt, in Seewald, Ken, and Sundeen, Dan, eds., The geologic framework of the Chihuahua tectonic belt: Midland, Texas, West Texas Geological Society, p. 67-74.

Brunner, P., 1975, Estudio estratigráfico del Devónico en el área de El Bísani, Caborca, Sonora: Instituto Mexicano del Petróleo, Revista, v. 7, p.16-45.

Brunner, P. 1976, Litología y bioestratigrafía del Misisípico en el área de Bísani, Caborca, Sonora: Instituto Mexicano del Petróleo, Revista, v. 8, p. 7-41. 
Bushnell, S.E., 1988, Mineralization at Cananea, Sonora, Mexico, and the paragenesis and zoning of breccia pipes in quartzofeldspathic rocks: Economic Geology, v. 83, p. 1760-1781.

Calmus, Thierry, 1993, Reconnaissance geologic map of the Estacion Sahuaro area (Altar district, Sonora): Tectonic implications, in Resumenes of the III Simposio de la Geología de Sonora y áreas adyacentes, C. González and L. Vega, eds., Hermosillo, Sonora, Mexico, Universidad Nacional Autónoma de México, and Universidad de Sonora, Departamento de Geología, p. 19-22.

Calmus, Thierry, Peréz-Segura, Efrén, and Stinnesbeck, Wolfgang, 1997, La structuration de la marge pacifique north-américane et du "terrane" Caborca: apports de la découverte d'une faune du Jurassique inférieur et moyan dans série de Pozos de Serna (Sonora, Mexique): C.R. Acad.Sci. Paris, Sciences de la terre et des planétes/Earth and Planetary Sciences, v. 325, p. 257-263.

Castro-Rodríguez, A.A., and Morfín-Velarde., Sergio, 1988a, Contribución a la geología del área Cerro de Oro: Departamento de Geología, Universidad de Sonora, Boletín, v. 5, no. 1 and 2, p. 25-39.

Castro-Rodríguez, A.A., and Morfín-Velarde, Sergio, 1988b, Geología de la Carta Rayón, con énfasis en el área Cerro de Oro, Sonora central: Tesis, Departamento de Geología, Universidad de Sonora, 85 p.

Cevallos-Ferríz, S., 1981a, Observaciones sobre los estromatolitos del Precámbrico Tardío de las capas Gamuza de la región de Caborca, Estado de Sonora: México, D.F., Universidad Nacional Autónoma de México, Facultad de Ciencias, tesis doctoral, 29 p.

Cevallos-Ferríz, S., 1981b, Modelo paleoambiental para los estromatolitos Precámbricos de Caborca, Estado de Sonora: Geological Society of America Abstracts with Programs, v. 13, no. 2, p. 49.

Cevallos-Ferríz, S., and Roldán-Quintana, J., 1984, Comentarios bioestratigráficos a las correlaciones de estratigrafía física, entre Precámbrico de Caborca, Son., México y SW de Estados Unidos: in Memoria: III Congreso Latinoamericano de Paleontología, p. 1-9.

Cevallos-Ferríz, Sergio, and Weber, Reinhard, 1980, Arquitectura, estructura y ambiente de deposito de algunos estromatolitos del Precámbrico sedimentario de Caborca, Sonora: Universidad Nacional Autónoma de México, Instituto de Geología, Revista, v. 4 , no. 2 , p. 97-103.

Cevallos-Ferríz, Sergio, and González-León, 1984, Estromatopóridos devónicos de los cerros Caloso y Tejano de la Sierra del Tule, Sonora, in Perrilliat, M.C., ed., Tercer Latinoamericano de Paleontología: Universidad Nacional Autónoma de México, Instituto de Geología Memoría, p. 103-112.

Cevallos-Ferríz, Sergio, Salcido-Reyna, Alfonso, and Pelayo-Ledezma, Andrés, 1981, Una nueva sección del Precámbrico de Sonora: Los estromatolitos y su importancia en estos estudios: Universidad Nacional Autónoma de México, Instituto de Geología, Revista, v. 5, no. 1, p. 1-16.

Cevallos-Ferríz, S.R.S., Salcido-Reyna, Alfonso, and Pelayo-Ledezma, Andrés, 1982, El registro fósil del Precámbrico: Notas Geológicas, Boletín de la Asociación de Egresados de Geológica de la Universidad de Sonora y de la Delegación Noroeste de la Sociedad Geología Mexicana, Hermosillo, Sonora, v. 2, p. 2-6.

Cevallos-Ferríz, Sergio (or S.R.S.); Pelayo-Ledezma, Andres; Salcido-Reyna, Alfonso; 1988, Presencia del estromatolito Colonnella Komar, 1964, y su contribución al esquema paleoecológico de la Formación Gamuza (Rifico) de Caborca, Sonora: Revista, Instituto de Geología, Universidad Nacional Autónoma de México, D.F., México, v. 7, no. 2, p. 206-216.

Chaparro-Meza, M.E., 1992, Geología de la carta Los Chinos H12C19 Sonora central: Hermosillo, Sonora, México, Universidad de Sonora, Departamento de Geología, tesis, $62 \mathrm{p}$. 
Consejo de Recursos Minerales, 1994, Geological-Mining Monograph of the State of Sonora.

Cooper, G. A., 1965, Fauna pérmica de El Antimonio, oeste de Sonora, Mexico: Mexico Universidad Nacional Autónoma de México, Instituto de Geología Boletín 58, pt. 3, $119 \mathrm{p}$.

Cooper, G.A., and Arellano, A.R.V., 1946, Stratigraphy near Caborca, northwestern Sonora, Mexico: American Association of Petroleum Geologists, v.30, no. 4, p. 606-619.

Cooper, G.A, Arellano, A.R.V., Johnson, J.H., Okulitch, V.J., Stoyanow, Alexander, and Lochman, Christina, 1952, Cambrian stratigraphy and paleontology near Caborca, northwest Sonora, Mexico: Smithsonian Miscellaneous Collections, v. 119 , no. $1,184 \mathrm{p}$.

Cooper, G. A., Dunbar, C. O., Duncan, Helen, Miller, A. K., and Knight, J. B., 1953, Permian fauna at El Antimonio, western Sonora, Mexico: Smithsonian Miscellaneous Collections, v. 119, no. 2, 111 p.

Cooper, G. A., Arellano, A.R.V., Johnson, J.H., Okulich, V.J., Stoyanow, A., and Lockman, C., 1954, Geología y paleontología de la región de Caborca, norponiente de Sonora. Part 1a. Paleontología y estratigrafía del Cámbrico de Caborca: Universidad Nacional Autónoma de México, Instituto de Geología, Boletín, v. 58, p. 259.

Chaparro-Meza, M.E., 1992, Geología de la carta Los Chinos H12C19 Sonora central: Hermosillo, Sonora, Mexico, Universidad de Sonora, Departamento de Geología, tesis, $62 \mathrm{p}$.

Corsetti, F.A.,. Stewart, J.H., Hagadorn, J.W., 2001, Neoproterozoic diamictite-cap cabonate succession from eastern Sonora, Mexico: Geological Society of America Abstracts with Programs, v. 33, p. A21.

Debrenne, Françoise, 1987, Archaeocyatha from Mexico in the Smithsonian Institution-New data from recent collectings: Lyon, France, Geobios, v. 20, no. 2, p. 267-273.

Debrenne, Françoise, Gandin, Anna, and Rowland, S.M., 1989, Lower Cambrian bioconstructions in northwestern Mexico (Sonora)_Depositional setting, paleoecology and systematics of archaeocyaths: Lyon, France, Geobios, no. 22, no. 2, p. 137-195.

DeJong, K.A., Escarcega-Escarcega, J.A., and Damon, P.E., 1988, Eastward thrusting, southwestward folding, and westward backsliding in the Sierra La Víbora, Sonora, Mexico: Geology, v. 16, p. 904-907.

Devery, J.P., 1979, Sedimentary petrology of the upper Paleozoic carbonates near Bavispe, Sonora, Mexico : Texas Christian University, M.S. thesis, 79 p.

Dumble, E.T., 1900, Notes on geology of Sonora, Mexico: American Institute of Mining Engineers Transactions, v. 29, p. 122-152.

Dunbar, C. O., 1939, Permian fusulinids from Sonora: Geological Society of America Bulletin, v. 50, p. 1745-1760.

Easton, W.H., 1958, Mississippian corals from northwestern Sonora, Mexico, in Easton, W. H., Sanders, J.E., Knight, J.B., and Miller, A.K., 1958, Mississippian fauna in northwestern Sonora, Mexico: Smithsonian Miscellaneous Collections, v. 119, no. 3, p. 1-40.

Eells, J.L., 1972, Geology of the Sierra de la Berruga, northwestern Sonora, Mexico: San Diego State University, M.S. thesis, 77 p.

Einaudi, M.T., 1982, Description of skarns associated with prophyry copper plutons, in Titley, S.R., ed. Advances in geology of the porphyry copper deposits: Tucson, Ariz., University of Arizona Press, p. 139-183.

Emmons, S.F., 1910, Cananea mining district of Sonora, Mexico: Economic Geology, v. 5, p. 312-356. 
Fernández-Aguirre, M.A., and Almazán-Vázquez, Emilio, 1991, Carta Geológica Arivechi: Gobierno del Estado de Sonora, Dirección General de Fomento Minero, Universidad Nacional Autónoma de México, Instituto de Geología, scale 1:50,000.

Fernández-Aguirre, M.A., Grijalva-Haro, A.S., and Cubillas-Estrada, 1995, Carta Geológica Sahuaripa, Sonora: Secretaría del Desarrollo Económico y Productividad, Dirección General de Fomento Minero y Centro de Estudios Superiores de Estatdo de Sonora (CESUES), publication 15, scale 1:50,000.

Fernández-Aguirre, M.A., Monreal-Saavedra, R., and Grijalva-Haro, A.S., 1993, Carta Geológica de Sonora: Centro de Estudios Superiores del Estado de Sonora (CESUES), 1:500,000 scale.

Figueroa-Valenzuela, M.C., and Grijalva-Haro, A.S., 1989, Geología de la Hoja Opodepe (H12D12), Municipio de Opodepe, Sonora, México: Hermosillo, Sonora, Mexico, Departamento de Geología, Universidad de Sonora, tesis, 83 p.

Fitts, D.E., 1989, Metasedimentary strata of Ejido Serdan, Mexico : San Diego State University, Department of Geological Sciences, M.Sc. thesis, 147p.

Flinn, D.L., 1977, Geology of the Cerro Macho area, Sonora, Mexico : Flagstaff, Ariz., Northern Arizona University, MS thesis, 73 p.

Flores, T., 1929a, Reconocimientos geológicos en la región central del estado de Sonora: Instituto Geólogica de México Boletín, v. 49, 254 p.

Flores, T. , 1929b, Reconocimientos geológicos de las zonas mineralozados en la región central del Estado de Sonora: Instituto Geología Mexicano Boletín, v. 49, 267 p.

Fritz, W.H., 1975, Broad correlations of some Lower and Middle Cambrian strata in the North American Cordillera: Geological Survey of Canada Paper 75-1, pt. A, p. 533540 .

Gastil, G., and Krummacher, D., 1977, Reconnaissance geology of coastal Sonora between Puerto Lobos and Bahía Kino: Geological Society of America, Bulletin, v. 88, p. $189-198$.

Gastil, G., and Miller, R. H., 1981, Lower Paleozoic strata on the Pacific plate of North America: Nature, v. 292, no. 5826, p. 828-830.

Gastil, G., and Miller, R. H., 1984, Prebatholithic paleogeography of Peninsular California and adjacent Mexico, in Frizzell, V.A., ed., Symposium on Baja California: Society of Economic Paleontologists and Mineralogists, Pacific Section, p. 9-16.

Gastil, G., Krummacher, D., and students at San Diego State University, 1974, Reconnaissance geologic map of coastal Sonora between Puerto Lobos and Bahía Kino: Geological Society of America Map and Chart Series MC-16, 1:150,000 scale.

Gastil, R. G., Miller, R., Anderson, P., Crocker, J., Campbell, M., Buch, P., Lothringer, C., Leier-Engelhardt, P., Delattre, M., and Hoobs, J., 1991, The relation between the Paleozoic strata on opposite sides of the Gulf of California: Geological Society of America Special Paper 254, p. 7-17 .

Gehrels, G.E., and Stewart, J.H., 1998, Detrital zircon U-Pb geochronology of Cambrian to Triassic miogeoclinal and eugeoclinal strata of Sonora, Mexico: Journal of Geophysical Research, v. 103, no. B2, p. 2471-2487.

Gilluly, J., Cooper, J. R., and Williams, J. S., 1954, Late Paleozoic stratigraphy of central Cochise County, Arizona: U.S. Geological Survey Professional Paper 266, $49 \mathrm{p}$.

González-León, C., 1980, La Formación Antimonio (Triásico Superior-Jurasico Inferior) en la Sierra del Alamo Estado de Sonora: Universidad Nacional Autónoma de México, Instituto de Geología, Revista, vol. 4, número 1, p. 13-18.

González-León, C., 1982, Biostratigrafía del Paleozoico de la Sierra del Tule, norte de Sonora (abs) : México, D.F., Sociedad Geológica Mexicana, VI Convención Nacional, p. 40-41. 
González-León, C., 1984, Estratigrafía y paleontología de la sección cámbrica-devónica de la Sierra del Tule, noreste de Sonora, México, in Perrilliat, M.C., ed., Tercer Congreso Latinoamericano de Paleontología: Universidad Nacional Autónoma de México, Instituto de Geología, Memoría, p. 18-27.

González-León, C.,1986, Estratigrafía del Paleozoico de la Sierra del Tule, noreste de Sonora: Universidad Nacional Autónoma de México, Instituto de Geología, Revista, v. 6 , no. 2 , p. $117-135$

González-León, C., 1987, La secuencia Paleozoica de la Sierra del Tule, Noreste de Sonora, in Paleozoico de Chihuahua, Excursión Geológica No. 2, Universidad Autónoma de Chihuahua, Gaceta Geológica, v.1, no. 1, p.97-104.

González-León, C., 1997, Sequence stratigraphy and paleogeographic setting of the Antimonio Formation (Late Permian-Early Jurassic) Sonora, Mexico, in C.D. Stanley, Jr., C. González-León, eds., Special issue dedicated to the International Workshop on the Geology of Northwestern Sonora, Mexico: Revista Mexicana de Ciencias Geológicas, v. 14, no. 2, p. 136-148

Griffith, Roger, and Hobbs, John, 1993, Geology of the southern Sierra Calamajue, Baja California Norte, Mexico, in R.G. Gastil and R.H. Miller, eds., The prebatholithic stratigraphy of Peninsular Californa, Geological Society of America Special Paper 279, p. 43-60.

Gross, E.L, Stewart, J.H., and Gehrels, G.E., 2000, Detrital zircon geochronology of Neoproterozoic to Middle Cambrian miogeoclinal and platform strata—northwest Sonora, Mexico: Geofísica International, v. 39, p. 295-308.

Guiza, Reinaldo, Jr., and White, D.E., 1949, Los yacimientos antimoniales de la región de El Antimonio, Estado de Sonora: Instituto Nacional para la Investigacion de Recursos Minerales Boletín 23, 48 p.(also published in English as White and Guiza, 1950).

Hagadorn, J.W. and Fedo, C.W., 2000, Terminal Proterozoic cloudiniids from Southwestern North America: Geological Society of America Abstracts with Programs, v. 32, no. 7, p. A300.

Hagadorn, J.W., and Waggoner, 2000, Ediacaran fossils from the southwestern Great Basin, United States: Journal of Paleontology, v. 74, n.2, p. 349-359.

Hamilton, Warren, 1987, Mesozoic geology and tectonics of the Big Maria Mountains region, southeastern Arizona, in Dickinson, W. R., and Klute, M. A., Mesozoic rocks of southern Arizona and adjacent areas: Arizona Geological Society Digest v. 18, p. 33-47.

Hewett, R. L., 1978, Geology of the Cerro La Zacatera area, Sonora, Mexico (MS thesis): Flagstaff, Ariz.,Northern Arizona University, 99 p.

Himanga, J.C., 1977, Geology of the Sierra Chiltepín, Sonora, Mexico: Flagstaff, Ariz., Northern Arizona University, M.S. thesis, 99 p.

Holcomb, R.A., 1979, Conodont biostratigraphy of the Paleozoic carbonates near Bavispe, Sonora, Mexico: Fort Worth, Texas Christian University, M.S. thesis, 99 p.

Imlay, R. W., 1939, Paleogeographic studies in northeastern Sonora: Geological Society of America Bulletin, v. 50, p. 1723-1744.

Ketner, K. B., 1983, Strata-bound, silver-bearing iron, lead, and zinc sulfide deposits in Silurian and Ordovician rocks of allochthonous terranes, Nevada and northern Mexico: U. S. Geological Survey Open-File Report 83-792, 6 p.

Ketner, K. B., 1986, Eureka Quartzite in Mexico?--Tectonic implications: Geology, v. 14, p. $1027-1030$.

Ketner, K.B., and Noll, J.H., Jr., 1987, Preliminary geologic map of the Cerro Cobachi area, Sonora, Mexico: U.S. Geological Survey Miscellaneous Field Studies Map MF-1980, scale 1:20,000

King, R. E., 1939, Geologic reconnaissance in northern Sierra Madre Occidental of Mexico: Geological Society of America Bulletin, v. 50, p. 1625-1722. 
Kurtz, J.R., Gehrels, G.E., and Stewart, J.H., 1998, Detrital zircon geochronology of the Bolsa Quartzite (Cambrian) in Sonora, Mexico: Geological Society of America

Abstracts with Programs, v. 30, no. 5, p. 49.

Leveille, G.P., 1984, Geology of El Capitan, Sonora, Mexico [M.Sc. thesis]: San Diego State University, Department of Geological Sciences, 122p.

Lochman, Christina, 1948, New Cambrian trilobite genera from northwest Sonora, Mexico: Journal of Paleontology, v. 22, no. 4, p. 451-464.

Lochman, Christina, 1953, Corrections to trilobites in "Cambrian stratigraphy and paleontolgy near Caborca", northwestern Sonora, Mexico: Journal of Paleontology, v. 27, no. 3, p. 486-488.

Longoria, J.F., 1981, Regional geology of northwest Sonora: Dallas, Texas, University of Texas, Guidebook-Field trip 4, Geological Society of America, Cordilleran section Annual Meeting, Hermosillo, Mexico, 174 p.

Longoria, J.F., and González, M.A., 1979, Estudios estratigraphico-estructurales en el Precámbrico de Sonora: Geología de los Cerros Gamuz y el Arpa: Universidad de Sonora, Boletín, v. 2, no 2, p. 106-149.

Longoria, J.F., and Pérez, V.A., 1978, Bosquejo geolgico de los Cerros Chino y Rajón, Cuadrangulo Pitiquito-La Primavera (NW de Sonora): Universidad de Sonora, Departamento de Geología, Boletín, ser. 1, v. 1, p. 119-144.

López-Ramos, E., 1982, Geología de México, Tomo II (tercera edición): México, D.F., Tesis Resendiz S.A., 454 p.

Lucas, S.G., and González-León, C.M., 1994, Marine Upper Triassic strata at Sierra La Flojera, Sonora, Mexico: Neues Jahrbuch für Geologie und Paläontologie, Mithandlung, Heft 1, p. 34-40.

Lucas, S.G., and Estep, J.W., 1999, Permian, Triassic, and Jurassic stratigraphy, biostratigraphy, and sequence stratigraphy in the Sierra del Alamo Muerto, Sonora, Mexico: in Bartolini, C., Wilson, J.L., and Lawton, T.F., eds., Mesozoic sedimentary and tectonic history of North-Central Mexico: Boulder, Colorado, Geological Society of America Special Paper 340, p. 271-286.

Lucas, S.G., Kues, B.S., Estep, J.W., and González-León, C., 1997, Permian-Triassic boundary at El Antimonio, Sonora, Mexico in G.D. Stanley, Jr., and C. GonzálezLeón, eds., Special issue dedicated to the International Workshop on the Geology of Northwestern Sonora, Mexico: Revista Mexicana de Ciencias Geológicas, v. 14, no. 2, p. p.149-154.

Lucas, S.G., Estep, J.W., and Molina-García, R.S., 1999, Early Jurassic stratigraphy and ammonites at Cerro Pozos de Serna, Sonora, Mexico, and their tectonic significance: Neus Jahrbuch für Geologie und Paläontologie, no. 6 (1999), p. 357-371.

Madrid, R.J., Poole, F.G., and Oliva-Becerril, J.F., 1988, Origin of stratiform barite in the Barita de Sonora mine area, central Sonora, Mexico [abs.], in Almazán-Vázquez, Emilio, and Fernández-Aguirre, M.A., eds., Resumenes Segundo Simposio sobre Geología y Minería de Sonora: Hermosillo, Mexico, Universidad Nacional Autónoma de México, Instituto de Geología, p. 40-42.

Madrid, R.J., Poole, F.G., and Oliva-Becerril, J.F., 1990, Origin of barite in the Barita de Sonora Mine area, central Sonora, Mexico [abs.]: Geological Society of America Abstracts with Programs, v. 22, no. 3, p. 38.

Martínez-García, Hector, and Soots-López, J. , 1994, Geología de la Hoja Banámichi H12B83, Municipios de Banámichi and Arizpe, Sonora centro-septentrional: Departamento de Geología, Universidad de Sonora, tesis, 87 p.

Maytorena-Silva, J. F., and Esparza-Yañez, F. A., 1990, The Cambrian succession of central Sonora: Tectonic implications: Geological Society of America Abstracts with Programs, v. 22, no. 3, p. 65. 
McMenamin, M.A.S., 1982, Precambrian conical stromatolites from California and Sonora: Bulletin of the Southern California Paleontological Society, v. 14, no. 9 and $10,3 \mathrm{p}$.

McMenamin, M.A.S., 1983, Lower Cambrian trilobites from the Sierra el Rajón, northwest Sonora, Mexico: Southern California Paleontological Society Special Publications 3, p. 83-89.

McMenamin, M.A.S., 1985, Basal Cambrian small shelly fossils from the La Ciénega Formation, northwestern Sonora, Mexico: Journal of Paleontology, v. 59, no. 6, p. 1414-1425.

McMenamin, M.A.S., 1987, Lower Cambrian trilobites, zonation and correlation of the Puerto Blanco Formation, Sonora, Mexico: Journal of Paleontology, v. 61, p. 738749

McMenamin, M.A.S., 1992, Two new species of the Cambrian genus Mickwitzia: Journal of Paleontology, v. 66, no. 2, p. 173-182.

McMenamin, M.A.S., 1996, Ediacaran biota from Sonora, Mexico: Proceedings of the National Academy of Science, USA, v. 93, p. 4990-4993.

McMenamin, M.A.S., Awramik, S.M., and Stewart, J. H., 1983, Precambrian-Cambrian transition problem in western North America: Part II. Early Cambrian skeletonized fauna and associated fossils from Sonora, Mexico: Geology, v. 11, p. 227-230.

McMenamin, M.A.S., Rowland, S.M., Nance, R.P., and Corsetti, Frank, 1992, Proterozoic fossils from Mexico: Kyoto, Japan, 29th International Geological Congress, Abstract Volume 2/3, p. 257.

McMenamin, M.A.S., Pittenger, S.L., Carson, M.R., and Larrabee, E.M., 1994, Upper Precambrian-Cambrian faunal sequence, Sonora, Mexico, and Lower Cambrian fossils from New Jersey, United States, in Studies of Stratigraphy and Paleontology in honor of Donald W. Fisher, New York State Museum Bulletin 481, 213-227.

Meinert, L.D., 1980, Skarn, manto, and breccia pipe formation in sedimentary rocks in the Cananea district, Sonora, Mexico: Stanford, Calif., Stanford University, PhD thesis, $232 \mathrm{p}$.

Meinert, L.D., 1982 Skarn, manto, and breccia pipe formation in sedimentary rocks of the Cananea mining district, Sonora, Mexico: Economic Geology, v. 77, p. 919-949.

Mendoza, J.J., 1981, Cerros Pitiquito, in Longoria, José, ed., Regional geology of northwest Sonora (Geological Society of America Cordilleran Section meeting guidebook, field trip 4): Hermosillo, Sonora, Universidad de Sonora, p. 65-91.

Mendoza-Córdova, Abraham, and Minjares-Rivera, V.A., 1989, Cartografía geológica del área Las Peñitas, Sierra Caracahui: Hermosillo, Mexico, Departamento de Geología, Universidad de Sonora, tesis, $65 \mathrm{p}$.

Menicucci, S., Mesnier, H.Ph., and Radelli, L., 1982, Permian, Triassic and Liassic sedimentation (Barranca Formation) of centrral Sonora, Mexico: Hermosillo, Sonora, Mexico, Soc. Geol. Mexicana, Delegación Noroeste, and Asoc. Egresados de Geología de la Universidad de Sonora, Notas Geológicas, v. 1, no. 3, p. 2-8.

Minjarez-Sosa, Ismael, Palafox, J.J., Torres, Yolanda, Martinez, J.A., and Rodriguez, Bernardo, 1985, Consideraciónes respecto a la estratigrafía y estructura del área de Sahuaripa-Arivechi: Universidad de Sonora, Departamento de Geología, Boletin, v. 2, no. 1 and 2, p. 90-105. See p. 92 for description of C. La Sata and C. El Mogallón

Minjarez-Sosa, Ismael, Ochoa, J.G., and Sosa-L., Porfirio, 1993, Geología de la Sierra Agua Verde, NE de Villa Pesqueira (Matape) [abs.] in González-León, Carlos, and Vega-Granillo, E.L., eds., Resumenes, Tercero Simposio de la Geología de Sonora y áreas adyacentes: Hermosillo, Sonora, Mexico, Universidad de Sonora and Universidad Nacional Autónoma de México, Instituto de Geología, p. 83-85.

Mitchell, G.T., 1928, The geology of Sonora: Science, n.s., v. 67, no. 1736, p. 373. 
Montaño, T.R., 1986, Estratigrafía del área El Tigre, noreste de Sonora [abs], in Rodríguez-Castañeda, J.L., Roldán-Quintana, Jaime, and Jacques-Ayala, César, eds., Nuevas Aportaciones a la Geología de Sonora: Hermosillo, Sonora, Mexico, Universidad Nacional Autónoma de Mexico, Instituto de Geología, p. 12-13.

Morales-Montaño, Mariano, 1990, Cambrian-Jurassic relations in Sonora, Mexico: Geological Society of America Abstracts with Programs, v. 22, no. 7, p. A114.

Morales-Montaño, Mariano, and Cota-Reyna, Javier, 1990, Nuevas localidades Cámbricas en Sonora: Geological Society of America Abstracts with Programs, v. 22, no. 3, p. 70.

Mulchay, R. B., and Velasco, J. R., 1954, Sedimentary rocks at Cananea, Sonora, Mexico and tentative correlation with the sections at Bisbee and the Swisshelm Mountains, Arizona: Mining Engineering, v. 6, no. 6, p. 628-632; also published as American Institute of Mining and Metallurgical Engineers Transactions, v. 199, p.

Murchey, B.L., 1990, Radiolarian biostratigraphy of Paleozoic siliceous sedimentary rocks in central Sonora, Mexico [abs]: Geological Society America Abstracts with Programs, v. 22, no. 3., p. 71.

Noll, J. H., Jr., 1981, Geology of the Picacho Colorado area, northern Sierra de Cobachi, central Sonora, Mexico: Flagstaff, Ariz., Northern Arizona University, M.S. thesis, $165 \mathrm{p}$.

Noll, J.H., Dutro, J.T., Jr., and Beus, S.S., 1984, A new species of the Late Devonian (Famennian) brachiopod Dzieduszyckia from Sonora, Mexico: Journal of Paleontology, v. 58, no. 6, p. 1412-1421.

Ochoa-Granillo, J.A., and Sosa-León, J.P., 1993, Geología y estratigraphía de la sierra Agua Verde on énfasis en el Paleozoico: Hermosillo, Sonora, México, Universidad de Sonora, tesis, 59 p.

Page, W.R., Poole, F.G., and Harris, A.G., 2000, Reinterpretation of stratigraphy and structure based on new mapping in the Rancho Las Norias area, central Sonora, Mexico, in T. Calmus and Pérez-Segura, eds., Libro de Resumenes, Cuarta Reunión sobre la Geología del Noroeste de México y Areas Adyacentes, Hermosillo, Sonora, March, 2000, Estación Regional del Noroeste, Instituto de Geología, Universidad de Sonora, Publicaciones Ocasionales No. 2, p. 85-86.

Palafox, J.J., and Martinez, J.A., 1985, Estratigrafía del área de Arivechi, Sonora: Universidad de Sonora, Departamento de Geología, Bulletín, v. 2, no. 1 and 2, p 3059

Palafox, J.J., Minjarez, J.I., Pubellier, M., and Rascon, B., 1984, Sobre la presencia de rocas del paleozoico superior en el área de Arivechi, Sonora, México: Universidad de Sonora, Departamento de Geología, Boletín, v. 1, no. 1, p. 60-62.

Palmer, A.R., 1981, On the correlation of Grand Cycle tops, in M.E. Taylor, ed., Short papers for the Second International Symposium on the Cambrian System: U.S. Geological Survey Open-File Report 81-743, p. 156-159.

Peabody, C.E., 1979, Geology and petrology of a tungsten skarn: El Jaralito, Baviacora, Sonora, Mexico: Stanford, Calif, Stanford University, Ph.D. dissertation, 82 p.

Peiffer-Rangin, Françoise, 1979, Les zones isopiques du Paléozoïque inférieur du nordouest mexicain, témoins du relais etre les Appalaches et la cordillère ouest américaine [Lower Paleozoic isopic zones in northwestern Mexico: Evidence of continuity between the Appalachians and the western American Cordillera]: Comptes Rendus Hebdomadaires des Séances de l'Acadé des Sciences de Paris, ser. D, v. 288, no. 20, p. 1517-1519.

Peiffer-Rangin, Françoise, 1988, Biostratigraphic study of Paleozoic rocks of northeastern and central Sonora, unpublished manuscript on file with J.H. Stewart, U.S. Geological Survey, Menlo Park, Calfifornia and F.G. Poole, U.S. Geological Survey, Denver, Colorado, 90 p. 
Peiffer-Rangin, Françoise, Echavarri-Pérez, Ariel, Salas-Pizá, Guillermo, and Rangin, Claude, 1980, Sur la présence d'Ordovicien supérieur à graptolites dans le nord-ouest du Mexique: Paris, Academia des Seances Comptes Rendus, v. 290, Ser. D., p. 1316.

Pelayo-Ledezma, Andres, and Salcido-Reyna, Alfonso, 1985, Observaciones geológicas paleoecológicas del Proterozoico de la Sierra del Viejo y localidades circundantes de la región de Caborca, Sonora : Hermosillo, Sonora, Universidad de Sonora, tesis, $40 \mathrm{p}$.

Pérez-Ramos, Olivia, 1992, Permian biostratigraphy and correlation between southwestern Arizona and Sonora: Hermosillo, Sonora, Mexico, Universidad de Sonora, Boletín, segunda epoca, v. 9, no. 2, p. 1-74

Pérez-Soto, Francisco, 1991, Reconocimiento geológico de la carta Félix Gómez entre los Municipios de Pitiquito y Carbó, Sonora, México: Hermosillo, Sonora, México, Universidad de Sonora, Departamento de Geología, tesis, 35 p.

Poole, F.G., and Amaya-Martínez, 2000, The Sonora orogen in the Barita de Sonora mine area east of Mazatán, central Sonora: Guide to Field Trip 3 (March 5, 2000) for the Fourth Sykmposium on the Geology of northwest Mexico and adjacent areas (March 6-8, 2000, Center for the Arts, University of Sonora, Hermosillo, Sonora, México, $27 \mathrm{p}$.

Poole, F.G., and Dutro, J.T., Jr., 1988, Late Devonian fossils in seafloor hydrothermalvent barites of Nevada (USA) and Sonora (Mexico) [extended abs.]: Barite Symposium Abstracts, Kutná Hora, Czechoslovakia, Geological Survey, Prague, p. 51-53.

Poole, F. G., and Hayes, P.T., 1971, Depositional framework of some Paleozoic strata in northwestern Mexico and southwestern United States: Geological Society of America Abstracts with Programs, v. 3, no. 2, p. 1-74.

Poole, F. G., and Madrid, R. J., 1986, Paleozoic rocks in Sonora (Mexico) and their relation to the southwestern continental margin of North America: Geological Society of America Abstracts with Programs, v. 18, no. 6, p. 720-721.

Poole, F. G., and Madrid, R. J., 1988a, Allochthonous Paleozoic eugeoclinal rocks of the Barita de Sonora mine area, central Sonora, Mexico in Rodríguez-Torres, Rafael, ed., El Paleozoico de la Región Central del Estado de Sonora: Libreto Guía de la Excursión Geológica para Segundo Simposio sobre la Geología y Minería del Estado de Sonora, Excursiónes de Campo, Instituto de Geología, Universidad Nacional Autónoma de México, Hermosillo, Sonora, p. 32-41.

Poole, F. G., and Madrid, R. J., 1988b, Comparison of allochthonous Paleozoic eugeoclinal rocks in the Sonoran, Marathon, and Antler orogens: Geological Society of America Abstracts with Programs, v. 20, no. 7, p. 267.

Poole, F.G., and Perry, W.J., Jr., 1997, The late Paleozoic Ouachita-Marathon-Sonora orogenic system along the southern margin of North America: Geological Society of America, Abstracts with Programs, v. 29, no. 2, p. 43.

Poole, F.G., and Perry, W.J., Jr., 1998, Laurentia-Gondwana continental margins in northern Mexico, and their late Paleozoic collision, in Program and Abstracts for Conference on Laurentia-Gondwanan Connections before Pangea (IGCP Project 376), Oaxaca City, Oaxaca, Mexico, October, 1998, p. 27

Poole, F. G., Muchey, B. L., and Stewart, J. H., 1983, Bedded barite of middle and late Paleozoic age in central Sonora, Mexico: Geological Society of America Abstracts with Programs, v. 15, no. 5, p. 299.

Poole, F.G., Stewart, J.H., and Armstrong, A.K., 1984, Newly discovered Paleozoic section in central Sonora, Mexico, in Geological Survey Research 1982, U.S. Geological Survey Professional Paper 1375, p. 66.

Poole, F.G., Madrid, R.J., and Morales-Ramirez, J.M., 1988, Paleozoic eugeoclinal rocks of the Sonoran orogen in the Barita de Sonora mine area, central Sonora, 
Mexico [abs.], in Almazán-Vázquez, Emilio, and Fernández-Aguirre, M.A., eds., Resúmenes, Segundo Simposio sobre Geología y Minería de Sonora: Hermosillo, Sonora, Mexico, Universidad Nacional Autónoma de México, Instituto de Geología, p. 50-51.

Poole, F.G., Madrid, R.J., and Morales-Ramirez, J.M., 1990, Sonoran orogen in the Barita de Sonora mine area, central Sonora, Mexico [abs.]: Geological Society of America Abstracts with Programs, v. 22, no. 3, p. 76.

Poole, F.G., Madrid, R.J., and Oliva-Becerril, J.F., 1991, Geological setting and origin of stratiform barite in central Sonora, Mexico, in Raines, G.L., Lisle, R.E., Schafer, R.W., and Wilkinson, W.H., eds., Geology and ore deposits of the Great Basin: Reno, Nev., Geological Society of Nevada, v. 1, p. 517-522.

Poole, F.G., Berry, W.B.N., and Madrid, R.J., 1993a, Allochthonous Ordovician eugeoclinal rocks on Turner Island, eastern Gulf of California, and their paleotectonic significance: Geological Society of America Abstracts with Programs, v. 25, no. 5, p. 134-135.

Poole, F.G., Berry, W.B., and Madrid, R.J., 1993b, Ordovician eugeoclinal rocks on Turner island in the Gulf of California, Sonora, Mexico [abs], in Gonzáles-León, Carlos, and Vega-Granillo, E.L., eds., Resumenes, Tercero Simposio de Sonora y áreas adyacentes: Hermosillo, Sonora, Mexico, Universidad de Sonora and Universidad Nacional Autónoma de México, Instituto de Geología, p. 103.

Poole, F. G., Stewart, J. H., Repetski, J.E., Harris, A. G., Ross, R.J., Jr., Ketner, K. B., Amaya-Martínez, R., and Morales-Ramirez, J. M., 1995a, Ordovician carbonateshelf rocks of Sonora, Mexico, in Cooper, J. D., Droser, M. L., and Finney, S. C., eds., Ordovician Odyssey: Short Papers for the Seventh International Symposium on the Ordovician System: Fullerton, Calif., Pacific Section Society for Sedimentary Geology (SEPM), book no. 77, p. 267-275.

Poole, F. G., Stewart, J. H., Berry, W. B. N., Harris, A. G., Repetski, J. E.,Madrid, R. J., Ketner, K. B., Carter, C., and Morales-Ramirez, J. M., 1995b, Ordovician ocean-basin rocks of Sonora, Mexico, in Cooper, J. D., Droser, M. L., and Finney, S. C., eds., Ordovician Odyssey: Short Papers for the Seventh International Symposium on the Ordovician System, Las Vegas,: Fullerton, Calif., Pacific Section Society for Sedimentary Geology (SEPM), book no. 77, p. 277-284.

Poole, F.G., Page, W.R., and Amaya-Martínez, R., 1997, Newly discovered Silurian carbonate-shelf rocks in west-central Sonora, Mexico: Geological Society of America Abstracts with Programs, v. 29, no. 6, p. 483.

Poole, F.G., Page, W.R., and Amaya-Martínez, R., 1998, Rocas Silúricas de plataforma en Sonora: Mundo Minero (México), Enero 1998, año 2, no. 18, p. 6, 9, 24.

Poole, F.G., Amaya-Martínez, R., and Page, W.R., 2000a, Silurian and Devonian carbonate-shelf rocks and Lower Jurassic sequence near Rancho Placeritas, westcentral Sonora: Guide to Field Trip 2 (March 4, 2000) for the Fourth Symposium on the Geology of Northwest Mexico and adjacent areas (March 6-8, 2000), Center for the Arts, University of Sonora, Hermosillo, Sonora, México, 24 p.

Poole, F.G., Amaya-Martínez, R., and Harris, A.G., 2000b, Early Mississippian North American carbonate-platform margin in west-central Sonora, in Libro de Resumenes para Cuarta Reunion sobre la Geología del Northoeste de México y áreas adyacentes, Hermosillo, Sonora, March 2000, Publicaciones Ocasionales No. 2, p. 95-96.

Pregger, B.H., 1981, A recently discovered Devonian bedded barite deposit in central Sonora, Mexico [abs.]: Geological Society of America Abstracts with Programs, v. 13 , no. 2 , p. 101.

Pubellier, M., Rangin, C., Rascon, B., Chorowicz, J., and Bellon, H., 1995, Cenomanian thrust tectonics in the Sahuaripa region, Sonora: Implications about northwestern Mexico megashears, in Jacques-Ayala, C, González-León, C.M., and 
Roldán-Quintana, J., eds., Studies on the Mesozoic of Sonora and adjacent areas: Geological Society of America Special Paper 301, p. 111-120.

Radelli, Luigi; Menicucci, Serge; Mesnier, H. Ph.; Araux, Elizabeth; Calmus, Thierry; Amaya-M., Ricardo; Barrera-M., Edgardo; Dominguez-P., Esteban; Navarro M., Luis; and Soto- C., Luis, 1987, Allochthonous Paleozoic bodies of central Sonora: Universidad de Sonora, Boletin del Departamento de Geología, Boletín Segunda Epoca, v. 4, nos. 1 and 2, p. 1-15.

Radelli, L., Monreal, R., Urrutia, J., Ochoa, A., 1996, Cerro de Oro, revisited, Geological Society of America Abstracts with Programs, v. 28, no. 7, p. 190-191.

Rangin, Claude, 1977, Tectonicas sobrepuestas en Sonora septentrional: Universidad Nacional Autónoma de México, Instituto de Geología, Revista, v.1, no. 1, p. 44-47.

Rangin, Françoise, 1978, Consideraciones sobre el Paleozoico Sonorense [abs.], in Nájera-Garza, Jesús, and Ortlieb, Luc, eds., Resumenes, First Simposio La Geología y Potencial Minero del Estado de Sonora: Hermosillo, Sonora, Mexico, Universidad Nacional Autónoma de México, Instituto de Geología, p. 107-109

Repetski, J. E., Harris, A. G., Stewart, J. H., Poole, F. G., and Morales-Ramirez, J. M., 1985, Early Ordovician conodonts from central Sonora, Mexico, in Alridge, R. J., Austin, R. L., and Smith, M. P., Fourth European Conodont Symposium (ECOS IV) Abstracts, Nottingham, England, distributed by A.L. Austin, Department of Geology, The University of Southhampton, Southhampton, England, p. 25-26

Riva, J.F., and Ketner, K.B., 1989, Ordovician graptolites from the northern Sierra de Cobachi, Sonora, Mexico: Transactions of the Royal Society of Edinburgh, Earth Sciences, v. 80, p. 71-90

Rivera-Carranco, Enrique, 1988, Condiciones paleoambientales de depósito de las formaciones cámbricas del área de Caborca, Sonora, Universidad Nacional Autónoma de México, Instituto de Geología, Revista, v. 7, no. 1, p. 22-27.

Rodríguez-Castañeda, J.L., 1981, Notas sobre la geología del área de Hermosillo, Sonora: Universidad Nacional Autónoma de México, Instituto de Geología, Revista, v. 5, no. $1, \mathrm{p} 30-36$

Rodríguez-Castañeda, J.L., 1984, Geology of the Tuape region, north-central Sonora, Mexico: Pittsburgh, Pa., University of Pittsburgh, M.S. thesis, 157 p.

Rodríguez-Castañeda, J.L., 1988, Estratigrafía de la región de Tuape, Sonora: Universidad Nacional Autónoma de México, Instituto de Geología, Revista, v. 7, no 1, p. 52-66.

Rodríguez-Castañeda, J.L., 1994, Geología del áreas El Téguadchi, Estado de Sonora, México: Revista Mexicana de Ciencias Geológicas, v. 11, no. 1, p. 11-28.

Roldán-Quintana, Jaime, 1994, Geología del sur de la sierra de Oposura, Moctezuma, Estado de Sonora, México: Revista Mexicana de Ciencias Geológicas, v. 11, no. 1., p. 1-10.

Roldán-Quintana, Jaime, and González-León, Carlos, 1985, Notas sobre el Triásico superior de la Sierra de la Flojera, Sonora, in Weber, Reinhard, ed., Simposio sobre floras del Triásico tardio su fitogeografía y paleoecología, III Congreso Latinoamericano de Paleontología, Instituto de Geología, Universidad Nacional Autónoma de México, México, D. F.

Rowland, S.M., Corsetti, Frank, and McMenamin, M.A.S., 1993, Carbon isotope stratigraphy of the Proterozoic-Cambrian section of the Caborca area, Sonora, Mexico--Preliminary results: Geological Society of America Abstracts with Programs, v. 25, no. 5, p. 140.

Schmidt, G. T.,1978, Geology of the northern Sierra El Encinals, Sonora, Mexico: MS thesis, Flagstaff, Ariz., Northern Arizona University, 80 p.

Signor, P.W., III, McMenamin, M.A.S., Gevirtzman, D.A., and Mount, J.F., 1983, Two new pre-trilobite faunas from western North America: Nature, v. 303, p. 415418. 
Silver, L. T., and Anderson, T. H., 1974, Possible left-lateral early to middle Mesozoic disruption of the southwestern North America craton margin [abs.]: Geological Society of America Abstracts with Programs, v. 6, p. 955-956.

Soto-Contreras, L. A., and Navarro-Martínez, L. A., 1987, Geología de la carta Tecoripa (H12D64) porción este central del estado de Sonora nuevas contribuciones al Paleozoico: Hermosillo, Sonora, México, Universidad de Sonora, tesis, 93 p.

Stewart, J.H., 1984, Stratigraphic sections of Lower Cambrian and upper Proterozoic rocks in Nye, Lander, and Lincoln Counties, Nevada, and Sonora, Mexico: U.S. Geological Survey Open File Report 84-691, 99 p.

Stewart, J.H., 2002, Speculative model of Permian truncation of Neoproterozoic and Paleozoic Cordilleran miogeocline in Sonora, Mexico: in Floyd Gray, ed., Contributions to the geology, basin framework, and metallogeny of the Nogales and Cananea 1:250,000-scale quadrangles and adjacent areas, northern Sonora, Mexico and southern Arizona: U.S. Geological Survey Open-File report, in press.

Stewart, J.H., McMenamin, M.A.S., and Morales-Ramirez, J.M., 1984, Upper Proterozoic and Cambrian rocks in the Caborca region, Sonora, Mexico-Physical stratigraphy, biostratigraphy, paleocurrent studies, and regional relations: U.S. Geological Survey Professional Paper 1309, 36p.

Stewart, J.H., Madrid, R.J., Poole, F.G., and Ketner, K.B., 1988, Studies of Late Proterozoic, Paleozoic, and Triassic rocks in Sonora, Mexico [abs.], in AlmazánVázquez, Emilio, and Fernánez-Aguirre, M.A., eds., Resumenes, Segundo Simposio sobre Geología y Minería de Sonora: Hermosillo, Mexico, Universidad Nacional Autónoma de México, Instituto de Geología, , p. 60-62

Stewart, J.H., Poole, F.G., Ketner, K.B., Madrid, R.J., Roldán-Quintana, Jaime, Amaya-Martínez, Ricardo, 1990, Tectonics and stratigraphy of the Paleozoic and Triassic southern margin of North America, Sonora, Mexico, in Gehrels, G.E. and Spencer, J.E., eds., Geologic excursions through the Sonoran Desert Region, Arizona and Sonora: Arizona Geological Survey Special Paper 7, p. 183-202.

Stewart, J.H., Amaya-Martínez, R., Stamm, R.G., Wardlaw, B.R., Stanley, G.D., and Stevens, C.H., 1997, Stratigraphy and regional significance of Mississippian to Jurassic rocks in Sierra Santa Teresa, Sonora, Mexico: Revista Mexicana de Ciencias Geológicas, v. 14, no. 2, p. 115-135.

Stewart, J.H., Poole, F.G., Harris, A.G., Repetski, J.E., Wardlaw, B.R., Mamet, B.L., and Morales-Ramirez, J.M., 1999a, Neoproterozoic (?) to Pennsylvanian inner-shelf, miogeoclinal strata in Sierra Agua Verde, Sonora, Mexico: Revista Mexicana de Ciencias Geológicas, v. 16, no. 1, p. 35-62.

Stewart, J.H., Blodgett, R.B., Boucot, A.J., Carter, J.L., and López, R., 1999b, Exotic Paleozoic strata of Gondwanan provenance near Ciudad Victoria, Tamaulipas, México, in Ramos, V.A., and Keppie, J.D., eds., Laurentia-Gondwana Connections before Pangea: Boulder, Colo., Geological Society of America Special Paper 336, p. 227-252.

Stewart, J.H., Gehrels, G.E., Barth, A.P., Link, P.K., Christie-Blick, N.and Wrucke, C.T., 2001, Detrital zircon provenance of Mesoproterozoic to Cambrian arenites in the western United States and northwestern Mexico: Geological Society of America Bulletin, v. 113, no. 10 p. 1343-1356.

Stewart, J.H., Amaya-Martínez, R., and A.R. Palmer, 2002, Neoproterozoic and Cambrian strata of Sonora, Mexico: Rodinian supercontinent to Laurentian Cordilleran margin, in Andy Barth, ed., Crustal evolution in the southwest USA: Geological Society of America Special Paper, in press.

Taliaferro, N.L., 1933, An occurrence of Upper Cretaceous sediments in northern Sonora, Mexico: Journal of Geology, v. 41, no. 1, p. 12-37.

Valentine, W. G., 1936, Geology of the Cananea Mountains, Sonora, Mexico: Geological Society of America Bulletin, v. 47, p. 53-86. 
Valenzuela-Rentería, M., and Aguirre-Fimbres, A. B., 1995, Carta Geológica Carbó, Sonora: Gobierno del Estado de Sonora, Dirección General de Fomento Minero, y Centro de Estudios Superiores del Estado de Sonora (CESUES), Publicacion No. 16, scale 1:50,000.

Vassallo, L.F., 1985, Sobre la evolution geológica de la parte central del Estado de Sonora-México y su relación con los depositos de grafito, in Weber, Reinhard, ed., Simposio sobre floras del Triásico Tardio su fitogeografía y paleoecología: Instituto de Geología, Universidad Nacional Autónoma de México, III Congreso Latinoamericano de Paleontologia, Memoría, p.87-100.

Vega-Granillo, R., 1996, La sierra de Mazatán, Sonora, México: Geología y análisis estructural de un complejo metamórfico en la parte sur de la provincia de "Basin and Range" [: Hermosillo, Sonora, Universidad de Sonora, Departamento de Geología, tesis, $128 \mathrm{p}$.

Vega-Granillo, R., and Araux-Sánchez, E., 1985, Estudio geológico de la Sierra La Campaneria y sus yacimientos minerales: Departamento de Geología, Universidad de Sonora, Boletín, v. 2, no. 1 and 2, p. 74-84.

Vega-Granillo, Ricardo, and Araux, Elizabeth, 1987, Estratigrafía del Paleozoico en el área del Rancho Las Norias, Sonora Central: Departamento de Geología, Universidad de Sonora, Boletín, v. 4, no. 1 and 2, p. 41-50.

Vega-G., Ricardo, and Araux, Elizabeth, 1988, Estratigrafía del Paleozoico en el área del Rancho Las Norias, Sonora central, in Rodríguez-Torres, Rafael, ed., El Paleozoico de la Región Central del Estado de Sonora: Libreto Guía de la Excursión Geológica para Segundo Simposio sobre la Geología y Minería del Estado de Sonora, p. 14-24.

Vega-Granillo, Ricardo, Pérez-Soto, Francisco, and Chaparro-Meza, Marín, 1991, Mantos de corrimiento y cabalgaduras imbricadas en Sonora Central: Departamento de Geología, Universidad de Sonora, Boletín, p. 37-46.

Vega-Granillo, Ricardo, Pérez-Soto, F., and Chaparro-Meza, M., 1993, Estratigrafía de la parte norte de las cartas Los Chinos y Féliz Gómez, Sonora, in González-León, Carlos, and Vega-Granillo, E.L., eds., Hermosillo, México, 3rd Simposio de la geología de Sonora y áreas adyacentes, Libro de Resumenes, Universidad de Sonora e Instituto de Geología, p. 129-132.

Velasco, J.R., Geology of the Cananea District, 1966, in Titley, S.R., and Hicks, C.L., eds., Geology of the prophyry copper deposits, southwestern North America: Tucson, Ariz., University of Arizona Press, p. 245-249.

Viveros-Martínez, A., 1965, Estudio geológico de la Sierra de Cabullona, Municipio de Agua Prieta, Estado de Sonora: México, D.F., Universidad Nacional Autónoma de México, Facultad de Ingeniería, tesis, 82 p.

Waggoner, B., 1999, Biogeographic analyses of the Ediacaran biota: a conflict with paleotectonic reconstructions: Paleobiology, v. 25, p. 4540-458.

Wardlaw, B.R., 1981, Paleoecology of Permian brachiopod faunas of northern Mexico: Geological Society of America Abstracts with Programs, v. 13, no. 2, p. 112.

Weber, Reinhard, and Cevallos-Ferríz, Sergio, 1980, El significado bioestratigráfico de los estromatolitos del Precambrico sedimentario de la región de Caborca, Sonora: Univeridad Nacional Autónoma de México, Instituto de Geología, Revista, v. 4, no. 2, p. 104-110.

Weber, Reinhard, Cevallos-Ferríz, S., López-Cortés, A., Olea-Franco, A., Singer-Sochet, S., 1979, Los estromatolitos del Precámbrico Tardío de los alrededores de Caborca, Estado de Sonora, I: Reconstrucción de Jacutophyton Shapovalova e interpretación paleoecológica preliminar: Universidad Nacional Autónoma de México, Instituto de Geología, Revista, v. 3, no. 1, p. 9-23.

Westerfield, M.J., 1988, Geology and magnetics of the Cerros Clemente-Llano Verde, northwestern Sonora, Mexico (M.S. thesis): Cincinnati, Ohio, University of Cincinnati, $124 \mathrm{p}$. 
White, D.E., and Guiza, Reinaldo, 1950, Antimony deposits of El Antimonio district, Sonora, Mexico: U.S. Geological Survey Bulletin 962-B, p. 81-119 (published in Spanish as Guiza and White, 1949)

Wrucke, C. T., and Armstrong, A. K., 1987, Paleozoic stratigraphic section in Dry Canyon, Whetstone Mountains, Cochise County, Arizona, in M. L. Hill (ed.), Geological Society of America Centennial Field Guide-Cordilleran Section, 1987:

Denver, CO, Geological Society of America , v.1, p. 29-34. 


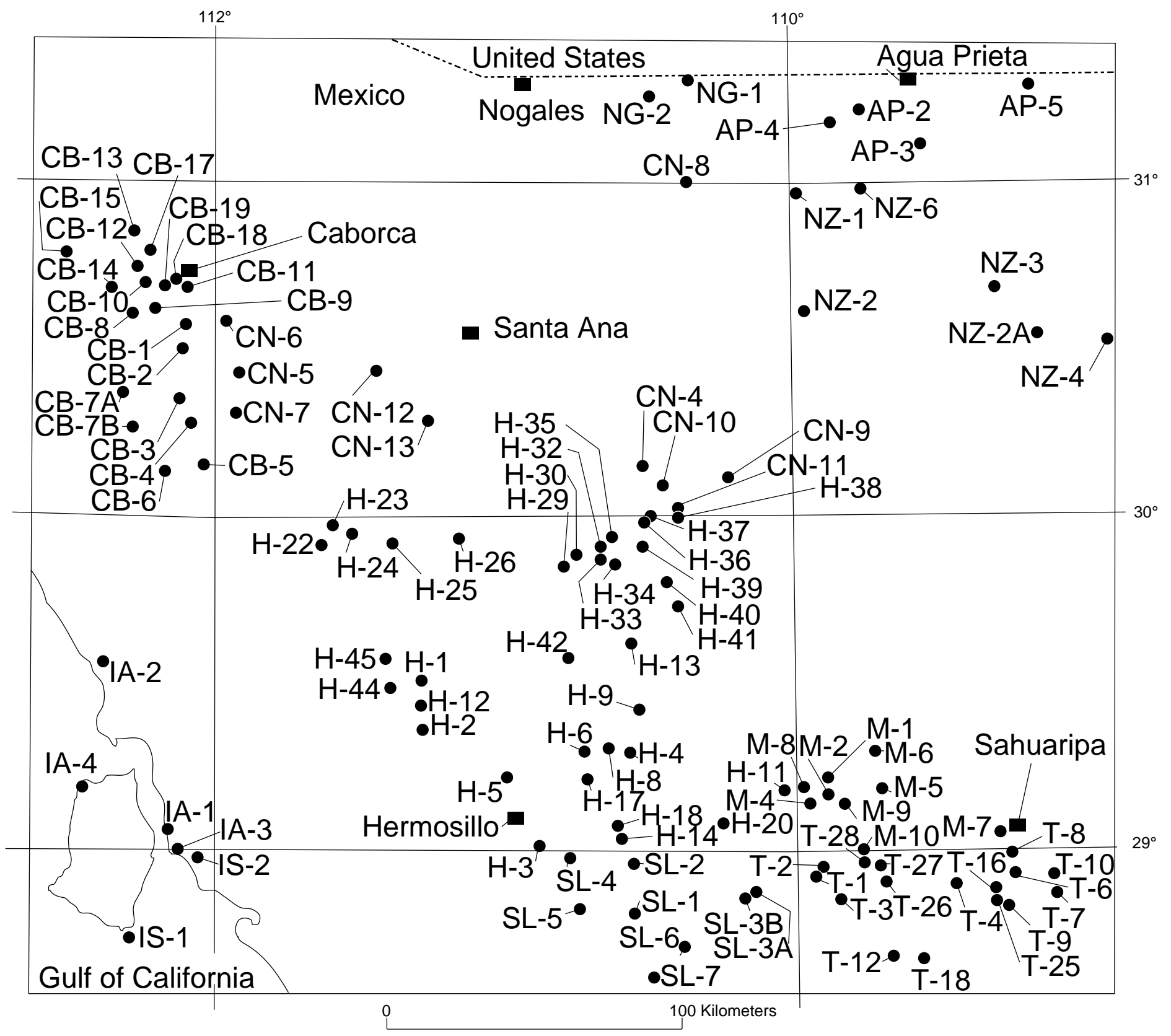

Figure 2. Index map of localities described in text. See introduction for explanation. 


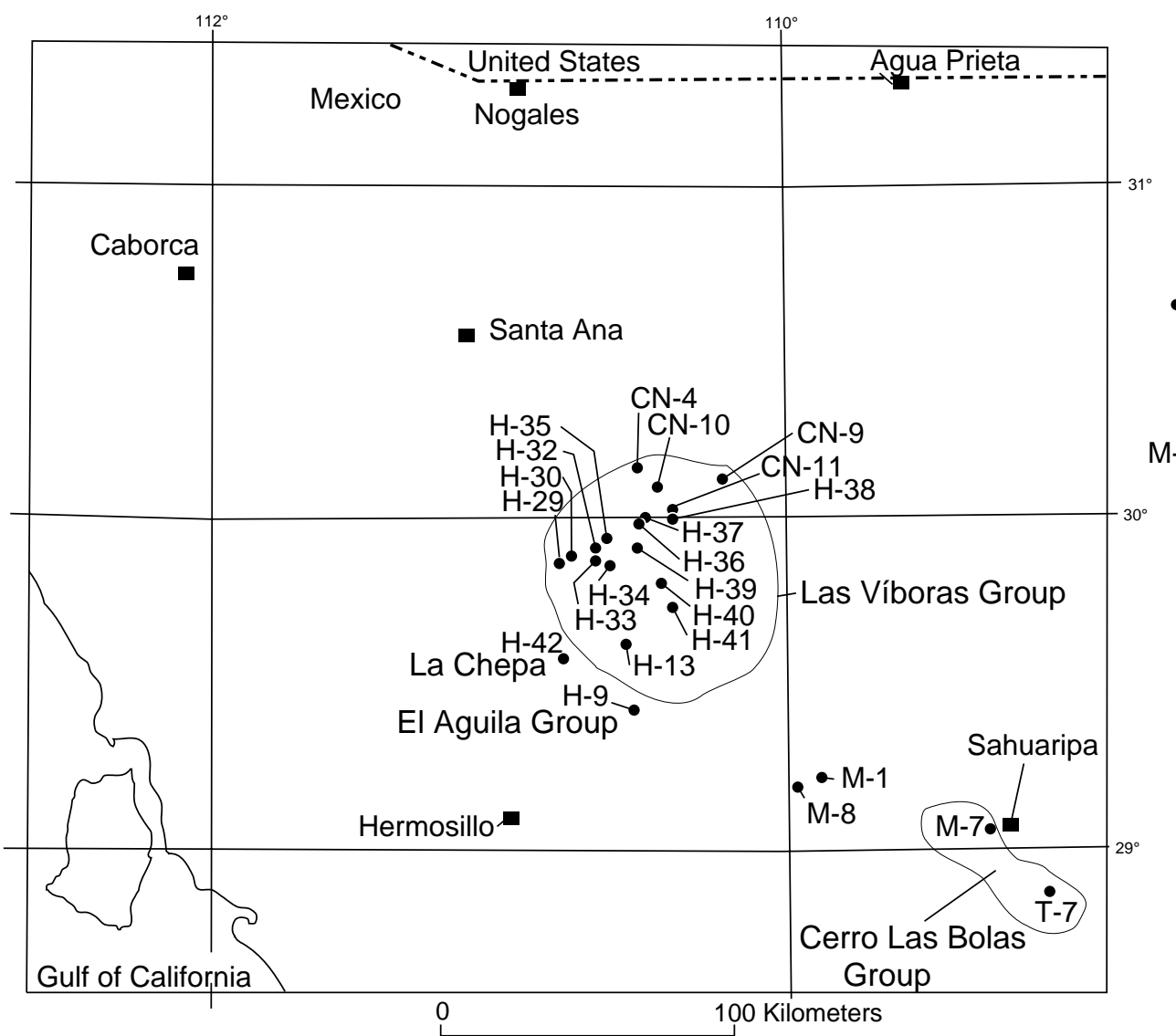

\section{EXPLANATION}

- Neoproterozoic strata older than Cordilleran miogeocline

M-1 Letter and number indicate locality designated in inventory

Figure 3. Distribution of Neoproterozoic strata older than Cordilleran miogeocline. About 1,000 to $750 \mathrm{Ma}$

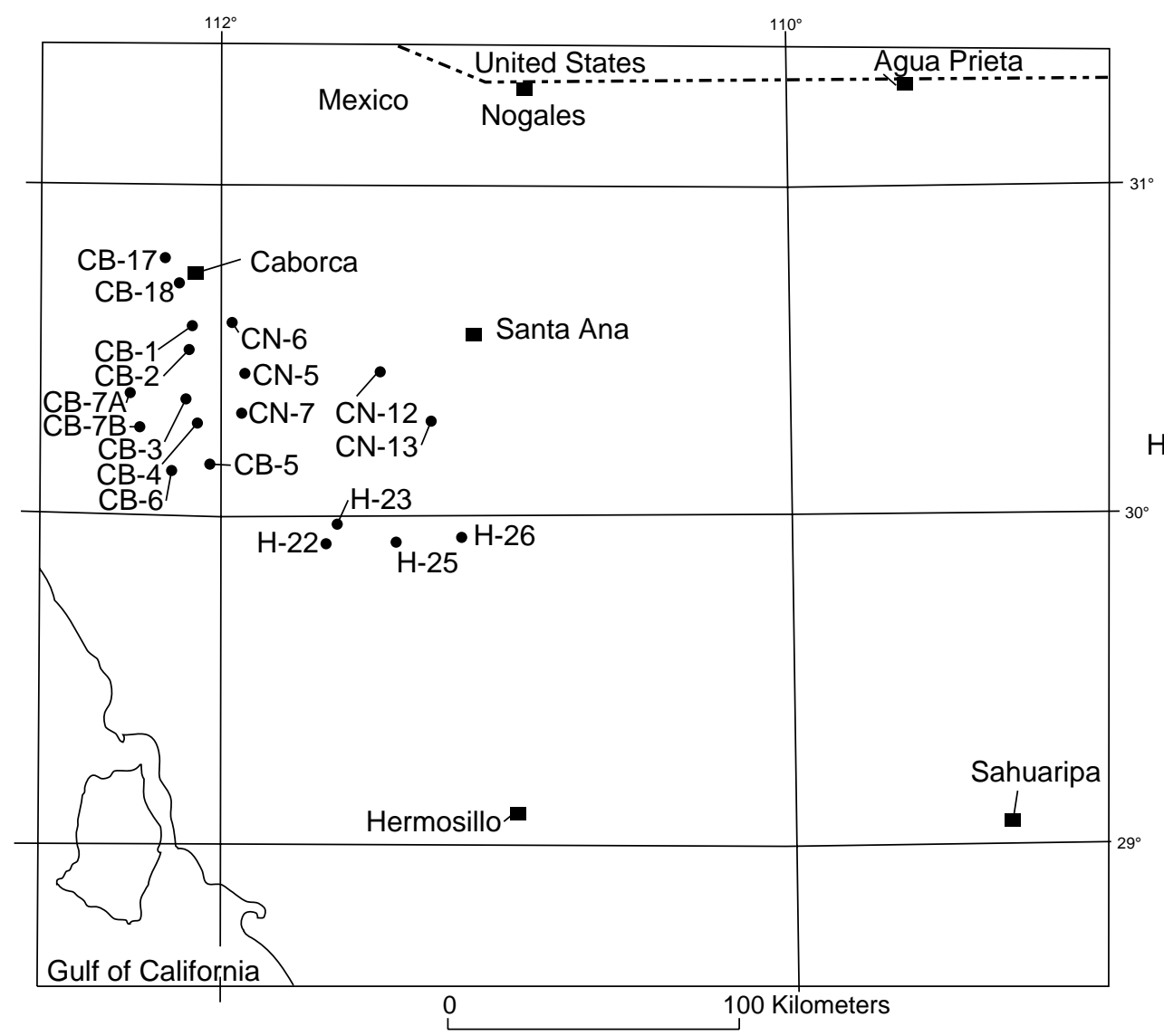

\section{EXPLANATION}

- Neoproterozoic strata in lower part of Cordilleran miogeocline

H-22 Letter and number indicate locality designated in inventory

Figure 4. Distribution of Neoproterozoic strata in lower part of Cordilleran miogeocline. About 750 to $540 \mathrm{Ma}$ 


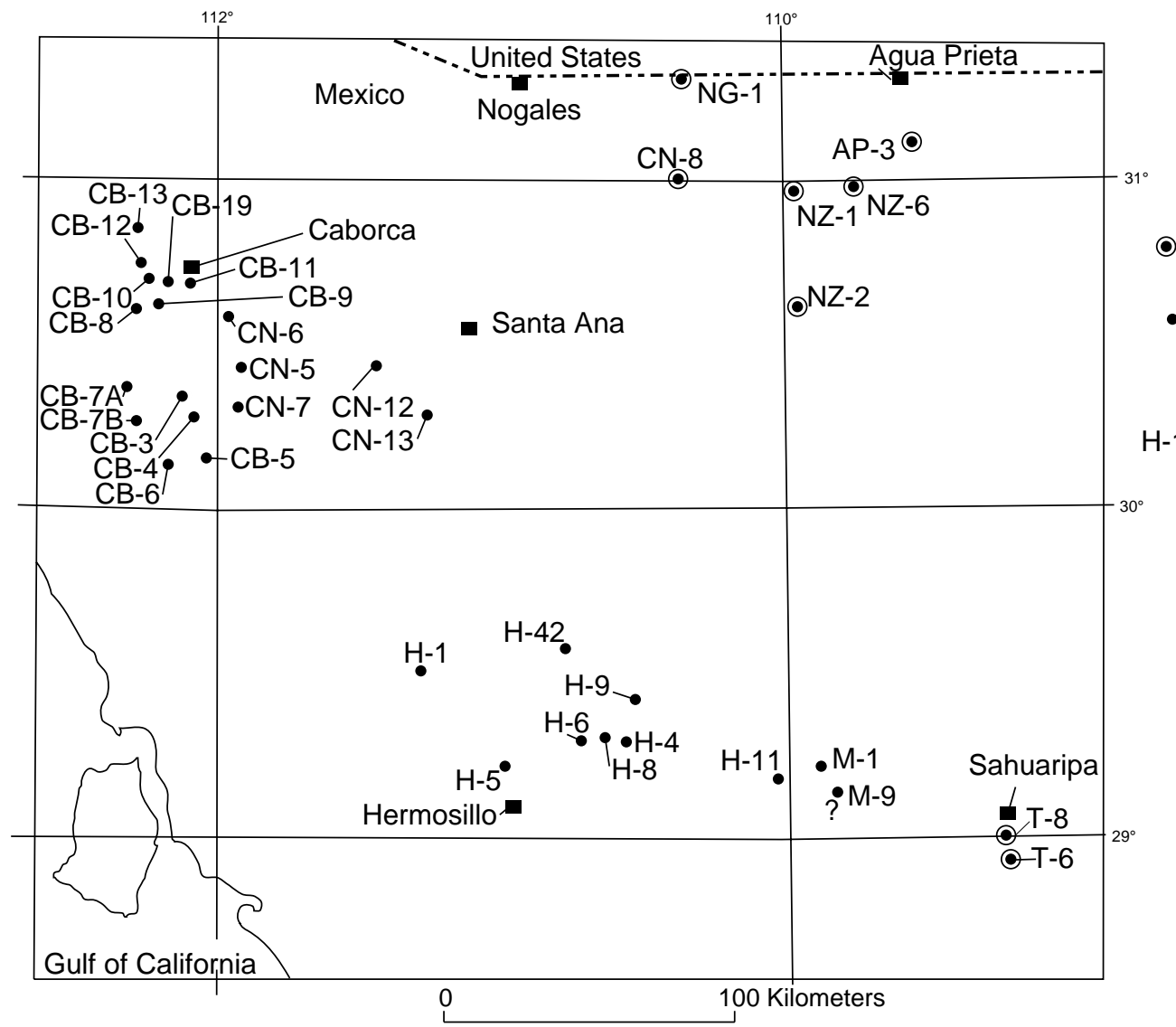

\section{EXPLANATION}

- Cambrian cratonal cover strata

- Cambrian shelf (miogeoclinal) strata

$\mathrm{H}-1 \quad$ Letter and number indicate locality designated in inventory.

Figure 5. Distribution of Cambrian strata in Sonora

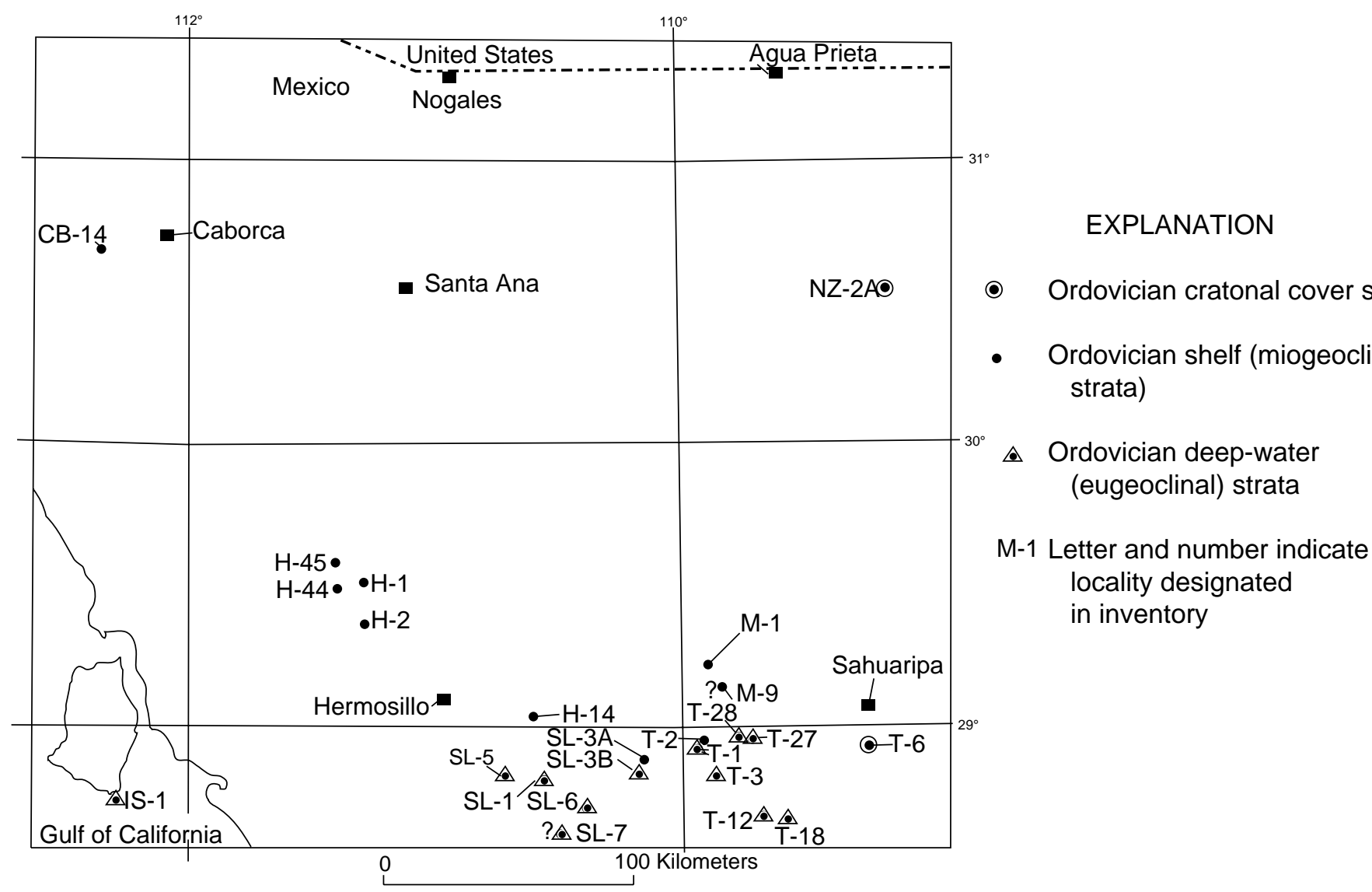

Figure 6. Distribution of Ordovician strata 


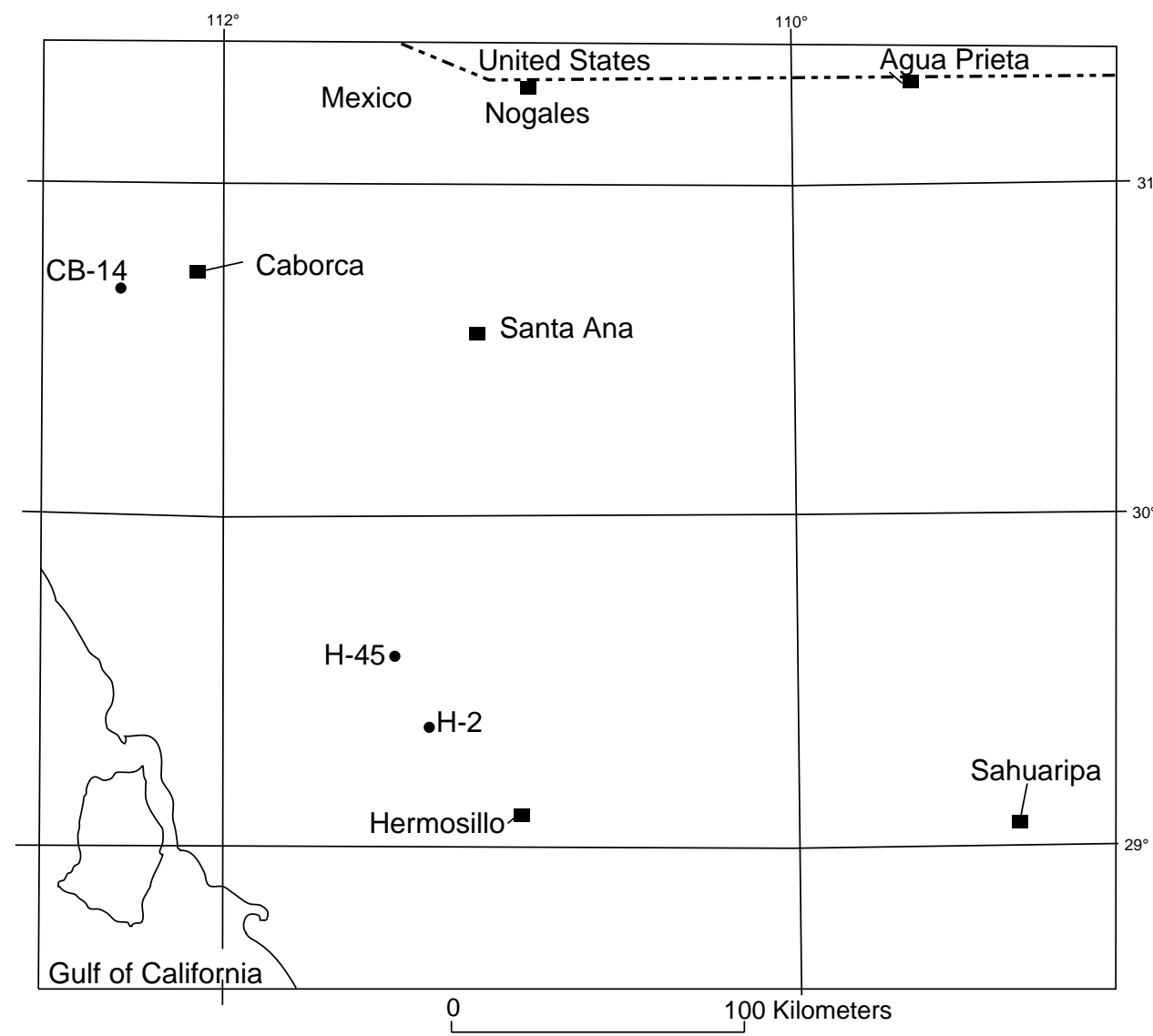

Figure 7. Distribution of Silurian strata

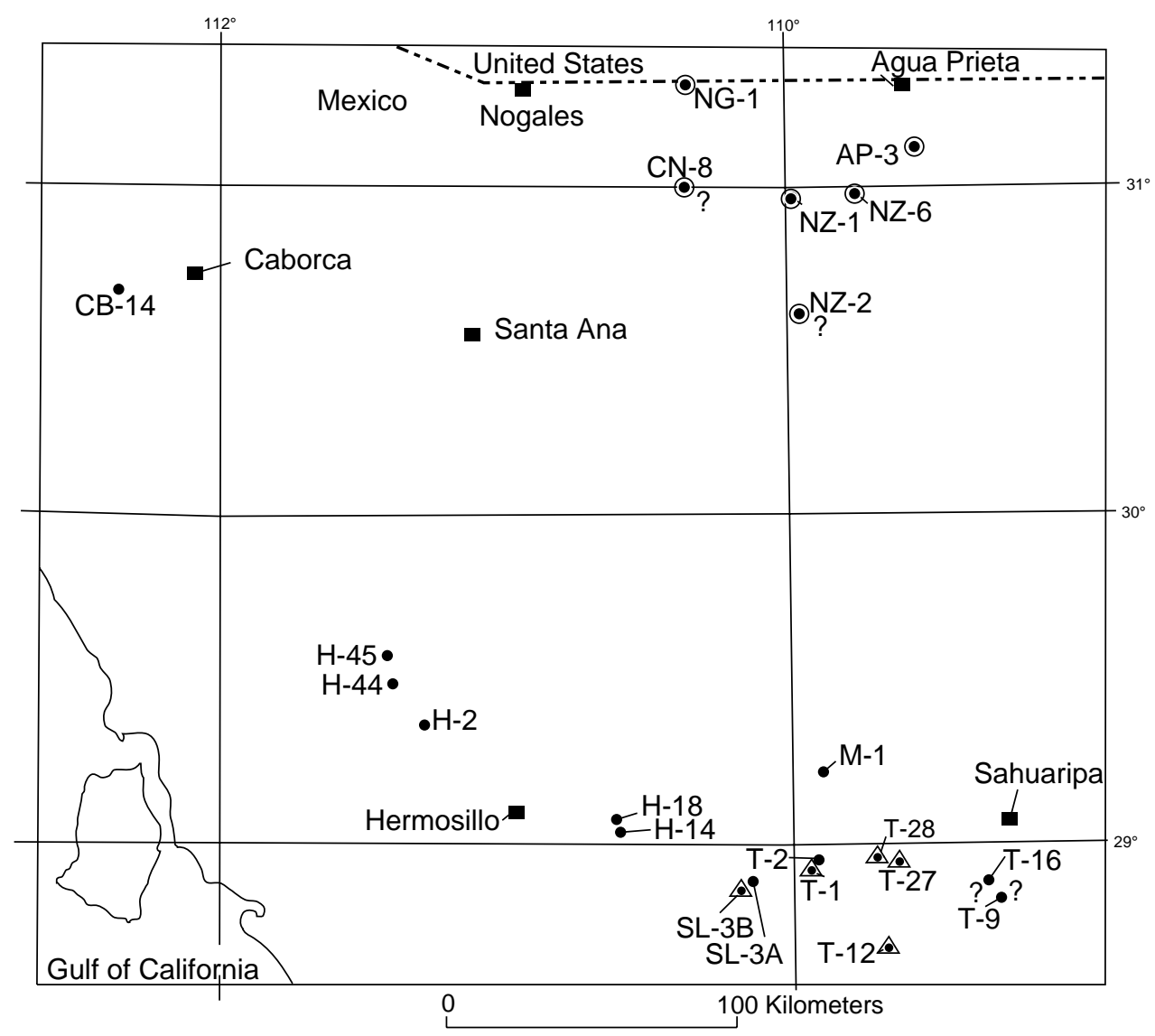

\section{EXPLANATION}

- Devonian cratonal cover

- Devonian shelf (miogeoclinal) strata

$\triangle$ Devonian deep-water (eugeoclinal) strata

$\mathrm{H}-2$ Letter and number indicate locality designated in inventory

Figure 8. Distribution of Devonian strata 


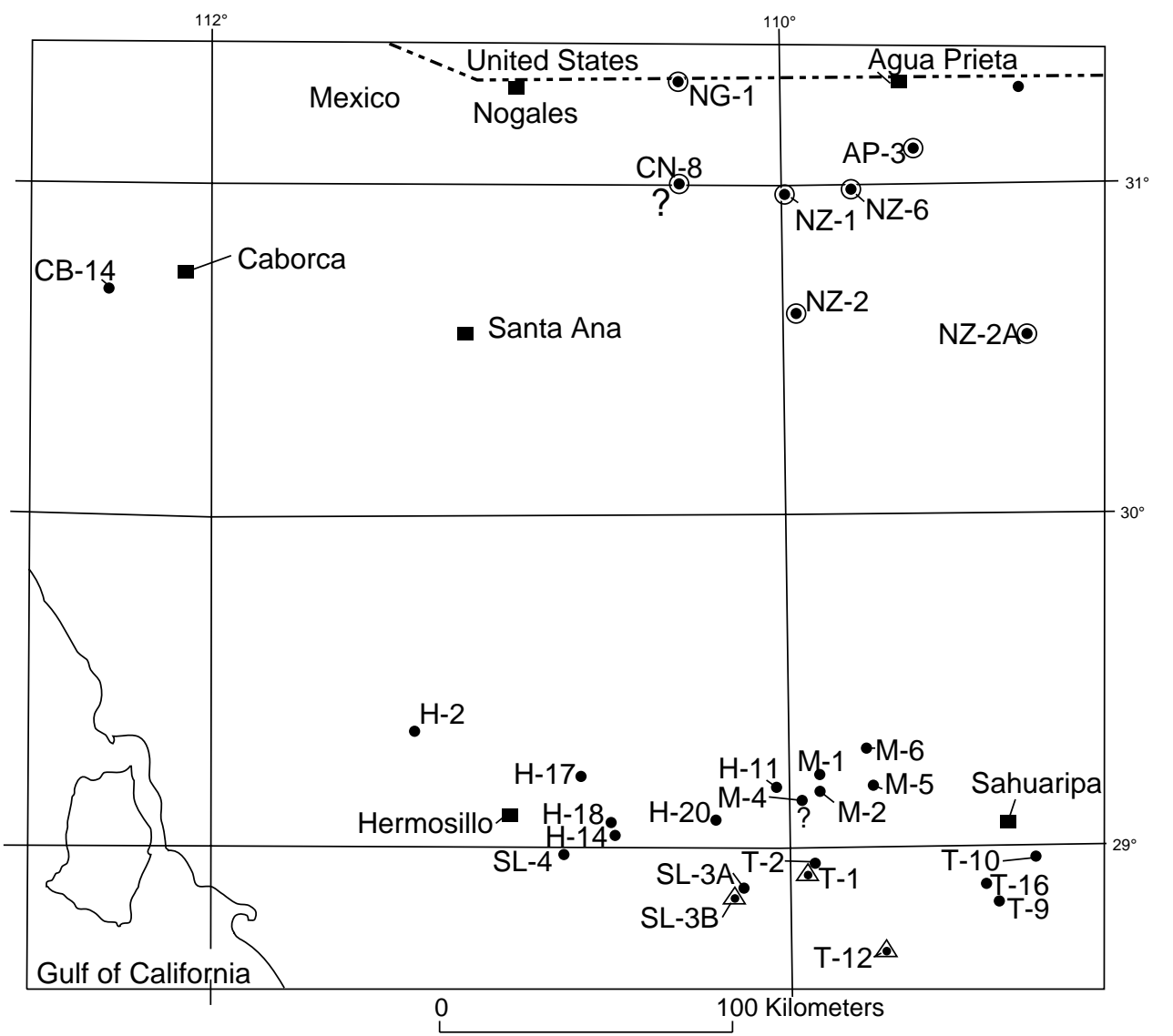

\section{EXPLANATION}

○ Misssisssippian cratonal cover strata

- Mississippian shelf (miogeoclinal) strata

$\triangle$ Misssissippian deep-water (eugeoclinal) strata

T-9 Letter and number indicate locality designated in inventory

? Age of strata uncertain

Figure 9. Distribution of Mississippian strata

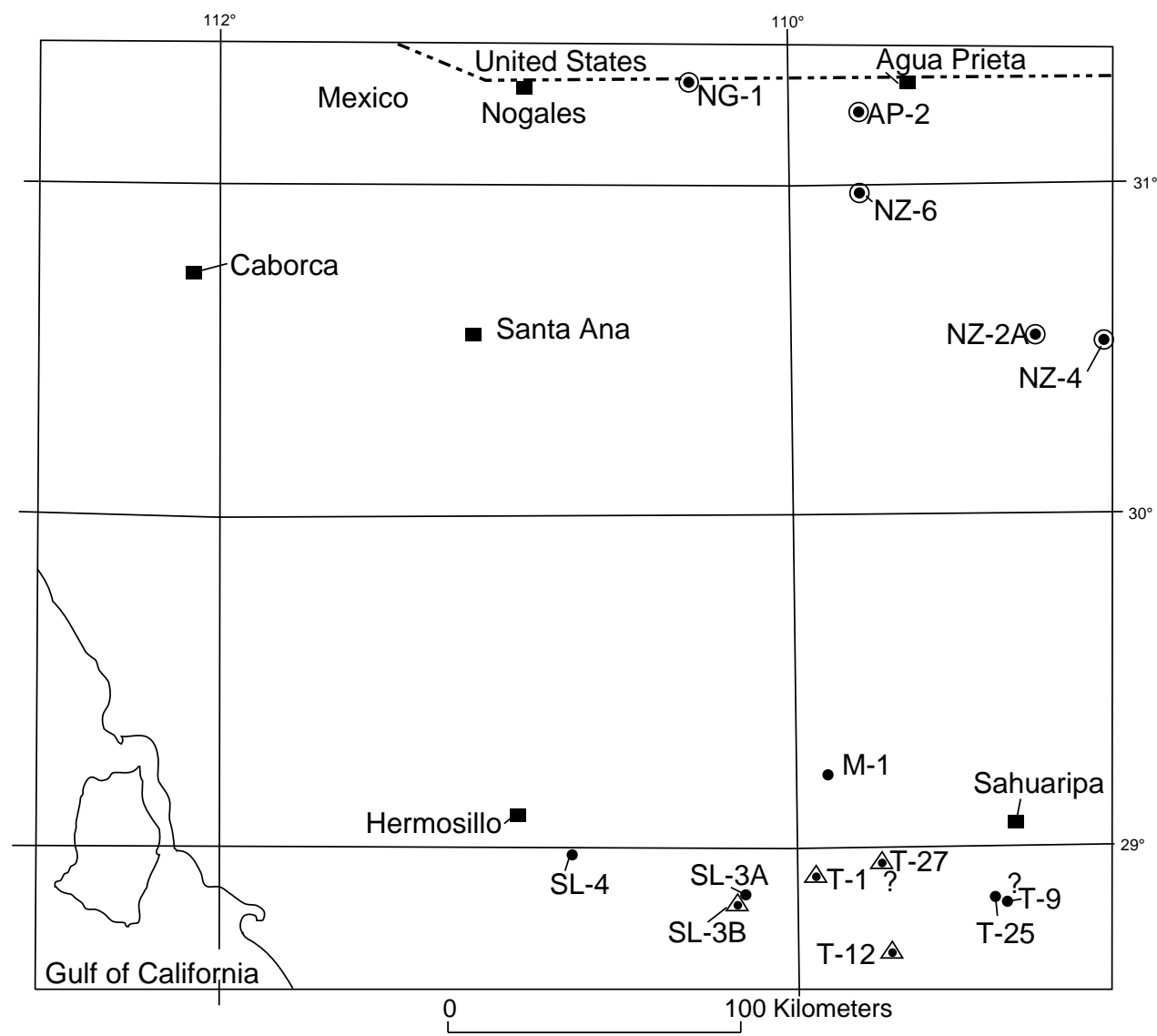

\section{EXPLANATION}

- Pennsylvanian cratonal cover strata

- Pennsylvanian shelf (miogeoclinal) strata

$\triangle$ Pennsylvanian deep-water (eugeoclinal) strata

T-9 Letter and number indicate locality designated in inventory

? Age of strata uncertain

Figure 10. Distribution of Pennsylvanian strata 


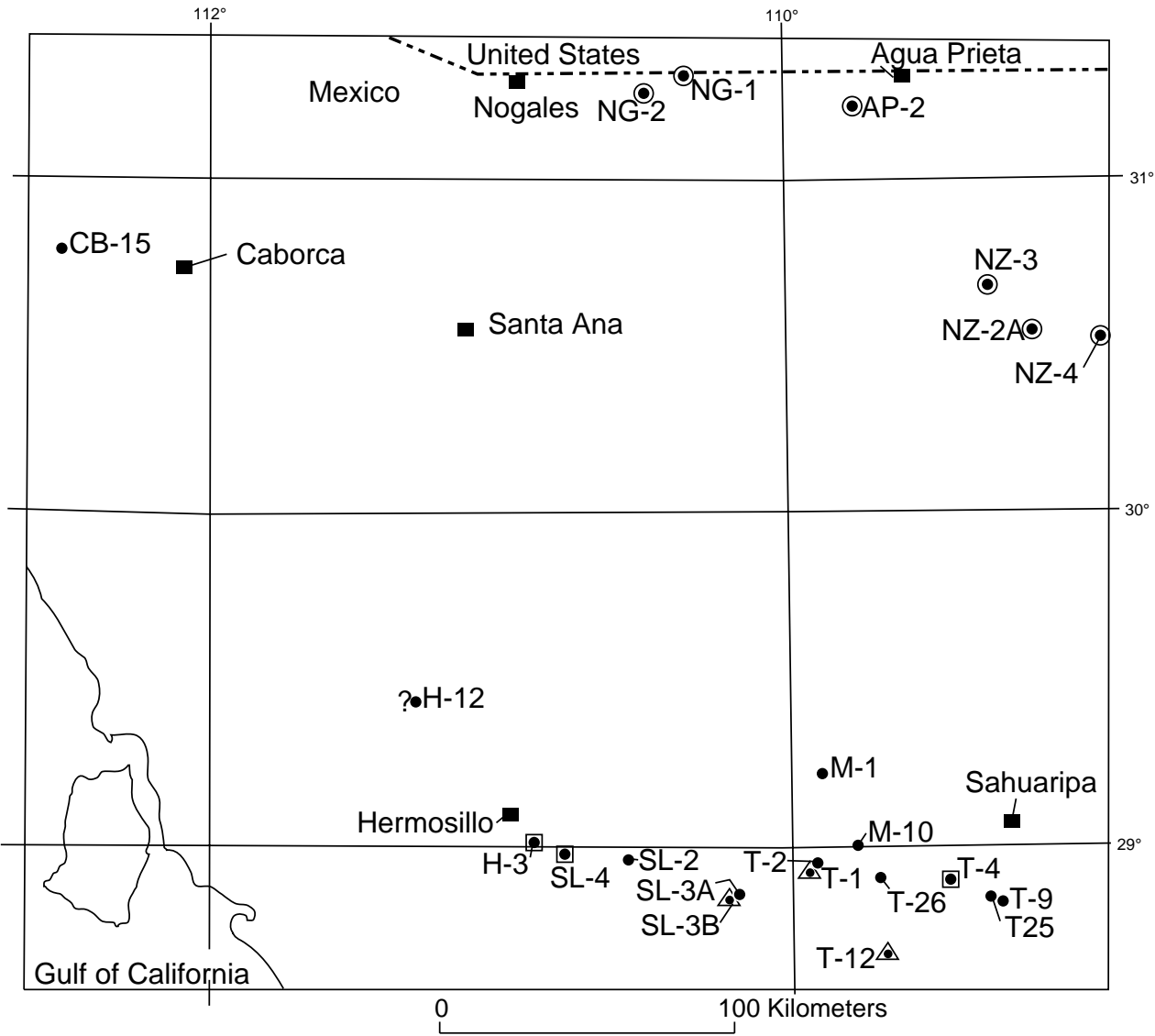

Figure 11. Distribution of Permian strata

\section{EXPLANATION}

- Permian cratonal cover strata

- Permian shelf (miogeoclinal) strata

- Permian shelf strata overlain depositionally or structurally by deep-water Permian clastic strata.

$\triangle$ Permian deep-water (eugeoclinal) strata

T-4 Letter and number indicate locality designated in inventory 